Florida International University FIU Digital Commons

\title{
Turkey and Neo-Ottomanism: Domestic Sources, Dynamics and Foreign Policy
}

Mustafa G. Sahin

Florida International University, msahi001@fiu.edu

DOI: $10.25148 /$ etd.FI10041623

Follow this and additional works at: https://digitalcommons.fiu.edu/etd

\section{Recommended Citation}

Sahin, Mustafa G., "Turkey and Neo-Ottomanism: Domestic Sources, Dynamics and Foreign Policy" (2010). FIU Electronic Theses and Dissertations. 160.

https://digitalcommons.fiu.edu/etd/160 


\section{FLORIDA INTERNATIONAL UNIVERSITY}

Miami, Florida

\section{TURKEY AND NEO-OTTOMANISM: DOMESTIC SOURCES, DYNAMICS AND FOREIGN POLICY}

A dissertation submitted in partial fulfillment of the requirement for the degree of DOCTOR OF PHILOSOPHY in INTERNATIONAL RELATIONS

by

Mustafa Gokhan Sahin

2010 
To: Dean Kenneth Furton

College of Arts and Sciences

This dissertation, written by Mustafa Gokhan Sahin, and entitled Turkey and Neo-Ottomanism: Domestic Sources, Dynamics and Foreign Policy, having been approved in respect to style and intellectual content, is referred to you for judgment.

We have read this dissertation and recommend that it be approved.

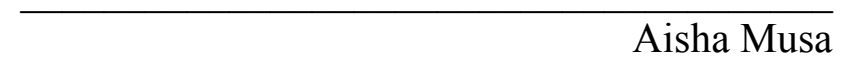

Aisha Musa

$\begin{array}{r}\text { Charles MacDonald } \\ \hline \text { Thomas Breslin } \\ \hline \text { Mohiaddin Mesbahi, Major Professor }\end{array}$

Date of Defense: March 26, 2010

The dissertation of Mustafa Gokhan Sahin is approved.

Dean Kenneth Furton

College of Arts and Sciences

Interim Dean Kevin O'Shea

University Graduate School

Florida International University, 2010 
C Copyright 2010 by Mustafa Gokhan Sahin

All rights reserved. 


\section{DEDICATION}

I dedicate this dissertation to my wife. Without her patience, understanding, support, and most of all love, the completion of this work would not have been possible. 


\section{ACKNOWLEDGMENTS}

I would like to thank Prof. Mesbahi and the members of my committee for their support and patience. Their gentle but firm direction has been most appreciated. 


\title{
ABSTRACT OF THE DISSERTATION \\ TURKEY AND NEO-OTTOMANISM: DOMESTIC SOURCES, DYNAMICS AND FOREIGN POLICY
}

\author{
by \\ Mustafa Gokhan Sahin \\ Florida International University, 2010 \\ Miami, Florida

\section{Professor Mohiaddin Mesbahi, Major Professor}

This study examined the relationship between the Turkish Islamic movements and the present government of the Justice and Development Party (Adalet ve Kalkinma Partisi, AK Party). Since the AK Party came to power in 2002 it implemented unparalleled political reforms and pursued to improve Turkey's relations with the EU. Opponents argued that because of the dominance of the secular military in Turkish politics, the AK Party is forced to secretly advance its Islamic agenda using the language and symbolism of democracy and human rights. This study argued that the ideas of the AK Party show similarities with the "Ottomanist" thought of the late Ottoman era. With special reference to the preservation of the Ottoman State, Ottomanism in an eclectic way was able to incorporate Islamic principles like freedom, justice and consultation into the political arena which was increasingly dominated by the secular European concepts.

Literature on Islam and politics in Turkey, however, disregards the Ottoman roots of freedom and pluralism and tends to reduce the relationship between religion and state into exclusively confrontational struggles. This conceptualization of the political process relies on particular non-Turkish Muslim experiences which do not necessarily represent 
Islam's venture in Turkey. Contrary to the prevailing scholarship, Islamic movements in Turkey, namely, Naqshbandi, National View and Nur, which are discussed in detail in this study, are not monolithic. They all uphold the same creedal tenets of Islam but they have sharp differences in terms of how they conceptualize the role of religious agency in politics. I argue that this diversity is a result of three distinct methodologies of Islamic religious life which are the Tariqah (Tarikat), Shariah (Şeriat), and Haqiqah (Hakikat). The differences between these three approaches represent a typological hierarchy in the formation of the Muslim/believer as an agent of Islamic identity. Through these different if not conflicting modes, the AK Party reconnected itself with Turkey's Ottoman heritage in a post-Ottoman, secular setting and was able to develop an eclectic political identity of Neo-Ottomanism that is evident in the flexibility if not inconsistency of its domestic and foreign policy preferences. 


\section{TABLE OF CONTENTS}

CHAPTER

PAGE

Chapter I: INTRODUCTION ……………………………………………………... 1

Chapter II: THREE ISLAMIC APPROACHES IN TURKEY ..................................... 19

Chapter III: NAQSHBANDI ORDER: TARIQAH.................................................. 51

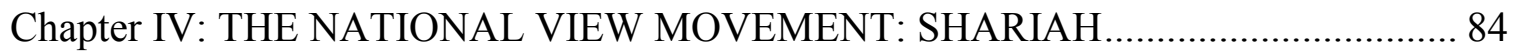

Chapter V: NUR AND GULEN MOVEMENTS: HAQIQAH .................................. 118

Chapter VI: AK PARTY AND NEO-OTTOMANISM ........................................... 169

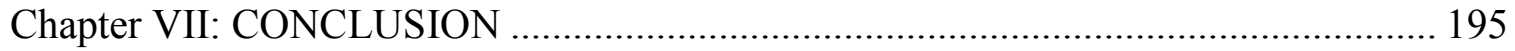

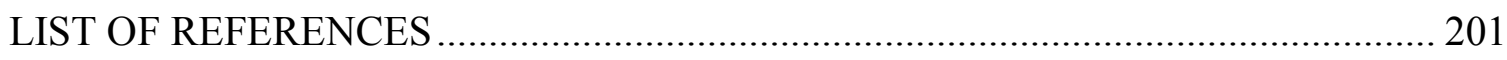

VITA

viii 


\section{LIST OF ACRONYMS}

\begin{tabular}{|c|c|}
\hline ANAP: & Motherland Party \\
\hline AK Party: & Justice and Development Party \\
\hline AP: & Justice Party \\
\hline CHP: & Republican People's Party \\
\hline Diyanet: & Directorate of Religious Affairs \\
\hline DP: & Democrat Party \\
\hline DYP: & True Path Party \\
\hline FP: & Virtue Party \\
\hline IDB: & Islamic Development Bank \\
\hline ITC: & Committee of Union and Progress \\
\hline MGH: & National View Movement \\
\hline MGK: & National Security Council \\
\hline MHP: & Nationalist Action Party \\
\hline MNP: & National Order Party \\
\hline MSP: & National Salvation Party \\
\hline MTTB: & National Turkish Students Union \\
\hline OIC: & Organization of Islamic Conference \\
\hline PKK: & Kurdistan Workers’ Party \\
\hline $\mathrm{RP}:$ & Welfare Party \\
\hline SP: & Felicity Party \\
\hline
\end{tabular}




\section{Chapter I: INTRODUCTION}

One of the most important political events in contemporary Middle East politics is the rise to power of the religiously oriented Justice and Development Party in 2002 with a landslide victory. Since it came to power, the Justice and Development Party (Adalet ve Kalkinma Partisi, AK Party) ${ }^{1}$ followed a "zero-problem" approach in Turkish foreign policy leading to the establishment of solid relationships with neighboring countries like Syria, Iran and Greece (with whom Turkey was at the brink of war a few years earlier). Domestically, Justice and Development Party began to carry out the reforms necessary for Turkey’s bid for EU membership faster than any previous Turkish government. ${ }^{2}$ The rise of the Justice and Development Party and its accomplishments have been a serious challenge to scholars of Middle East politics who, for the most part, could not anticipate a pro-Western, conservative Muslim political party rooted in domestic Islamic social movements coming to power democratically, and not threatening the existence of the secular state. ${ }^{3}$

In order to examine the significance of this transformation one should understand the nature of Islamic social movements, Islamic political parties and their place in Turkey's recent history. Scholars from different perspectives have offered varying

\footnotetext{
${ }^{1}$ Since the establishment of Justice and Development Party (Adalet ve Kalkinma Partisi in Turkish) its acronym has been part of an unresolved debate. According to official party records given to the Ministry of Interior the acronym is "AK Parti." In Turkish "ak" means white and clean; a clear reference to the party image of uncorrupted character. Many scholars (and most political opponents) use AKP (or JDP in English). This work will use AK Party.

${ }^{2}$ Sultan Tepe states that "in just two short years in power the JDP [Justice and Development Party] has done pathbreaking work, adopting more than five hundred laws - a record number for any elected Turkish government." For more see Tepe 2005, 80.

${ }^{3}$ Smith 2005a. Tepe calls this process a "quiet revolution," see Tepe 2005.
} 
definitions of Islamic social movements. Most of them, however, betray a structural bias in explaining the diverse array of social movements, thus limiting our ability to analyse the identities of these social movements in the public sphere. In explaining Islamic social movements, I employ Tarrow's definition, with minor modifications. Throughout this dissertation, a social movement will be considered as a collective understanding and action by people with common purposes and solidarity in sustained interaction with other social actors. ${ }^{4}$

Naqshbandi tariqah is the main historical-cultural Islamic movement in Turkey. For the past two hundred years, this tariqah expanded from being one of many Islamic movements into the most influential one due to its methods which proved successful when Turkish political and social life underwent a period of reform. In modern Turkey the Naqshbandi tariqah has branched off into various subgroups under the umbrella of the Naqshbandiyya. ${ }^{5}$ In this dissertation, only the major personalities and groups within the Naqshbandi order are analyzed.

The significance of the Naqshbandi order becomes clearer when the republican era of Turkish history is explored. From the establishment of the republic in 1923 by Mustafa Kemal (d. 1938) until 1945, Turkey was under a single party regime, the Republican People's Party (Cumhuriyet Halk Partisi, CHP). After two failed attempts, in 1924 and 1930, of leading political fugures to establish an opposition party, in 1945 Nuri Demirag established the National Development Party (Milli Kalkinma Partisi, MKP). MKP was liberal in economic policies but Islamist in cultural orientation. Although MKP

\footnotetext{
${ }^{4}$ Tarrow 1994, 3-4.

${ }^{5}$ Naqshbandiyya means Naqshbandi Order.
} 
was more religious in character, the secular Democrat Party (Demokrat Party, DP) (established in 1946 by the dissidents from the ruling Republican People's Party) gained the support of religious Muslims, especially followers of Said Nursi, and came to power with over $50 \%$ of the votes. Since the 1950 s the Islamic parties that gained the support of the voting block of Islamic movements affiliated with Naqshbandi order were increasingly successful.

The DP government was later toppled by the military in 1960. Since the 1960 coup, one that came with constitutional mandates empowering the military establishement, Turkish political life became a playground for the military officers who rotated easily controlled politicians one after the other. As a result, only a handful of politicians were able to continue their political career while the military was directly or indirectly involved in the political process. Therefore, from the 1960s until today four major politicians dominated Turkish political life: Suleyman Demirel (Center Right, 1964-2000), Alparslan Turkes (Nationalist, 1965-1997), Bulent Ecevit (Center LeftLeftist, 1966-2002) and Necmettin Erbakan (Center Right-Islamist 1969- 2002). Due to the anti-democratic nature of the political process, laws were passed which enabled these leaders to centralize control over the entire party structure (including but not limited to approving memberships and candidates, opening branches, and setting the ideological orientation of the party). In Turkish political history, there is almost no example of successful opposition candidates challenging incumbent party leaders.

Islamist parties were not an exception to this dynamic. With the support of a Naqshbandi leader, Zahid Kotku, in 1970 Erbakan established the National Order Party (Milli Nizam Partisi, MNP) as the political branch of the Naqshbandi order. Gradually, 
however, Erbakan, as a charismatic leader, took sole control of the party, naming his movement Islamist National View Movement (Milli Gorus Hareketi, MGH). Due to his authoritarian style, other members of Islamic movements left his movement during the mid-1970s. However on their own they could not become as succuesful as Erbakan; it was only after the year 2000 that a major division within the MGH led to the establishment of a successful alternative, AK Party.

Leaders of AK Party argued that the ideas and policies of their party are closer to contemporary European attitudes on democracy, human rights, and open economies. However, the Justice and Development Party's earlier association with the MGH caused suspicion in Middle Eastern and Islamic studies about the actually degree of ideological differences. The general analysis sees the Justice and Development Party as an ideological clone and offshoot of the Islamist National View Movement, discounting the Justice and Development Party's diverse background with the traditional Islamic movements who, contrary to their counterparts in the Middle East, historically had a special relationship with the state in Turkey. A close look at the tradition of Islamic movements in Turkey and their influence over the Justice and Development Party prove that the unique relationship between Islam and the contemporary state in Turkey cannot be referenced exclusively to the National View Movement.

The Justice and Development Party's rise to power and general success mark it as the main Islamic actor in a country where Islam has been represented by a diversity of other movements. However, the Justice and Development Party's success does not come from any single organic link with Islamic movements but is rather a result of the confluence of different understandings of and approaches to Islam blended with Turkish- 
Ottoman identity. Therefore, with regards to the changes in Turkish politics I will try to utilize the concept of "Neo-Ottomanism" to represent the unique relationship between religion, representing the Ottoman past, and the secular state, established after 1923.

The immediate rise of the Justice and Development Party occurred in the context of the complex political upheavals of the late 1990s. This era was known in Turkish politics as the $28^{\text {th }}$ February Process ( 28 Şubat Süreci), a reference to the famous February 28, 1997 National Security Council (Milli Güvenlik Kurulu, MGK) meeting dominated by secularist generals who ousted the Islamists from government. This 'soft coup d'état,' as many Turks now call it ${ }^{6}$, banned the Welfare Party which represented Erbakan's Islamist National View Movement in the parliament. Later, the members of the National View Movement established the Virtue Party (Fazilet Partisi, FP). In continuation of the $28^{\text {th }}$ February Process initiated by the secular army and its supporters in the judiciary, the Constitutional Court banned the Virtue Party. The policies of the National View Movement leadership then came under scrutiny within the party by a new generation of religiously sympathetic political leaders both in terms of substance and style.

For many, the closure of Islamic parties by the secular establishment was aimed at giving a clear message to Islamists that the road to political power as a religious party was a non-starter. However, the policies of the Justice and Development Party, as an Islamically oriented political party, are different from its predecessors. Furtermore, the Justice and Development Party's electoral success shows that wider sectors of the

\footnotetext{
${ }^{6}$ Yavuz 2003. See also Kuru 2009, 161.
} 
population rather than the mere supporters of Islamist National View Movement share their ideas. ${ }^{7}$

\section{Main Characteristics of the Literature on Islam in Turkey: Religion, Secularism and Identity between Rupture and Continuity}

Since the establishment of the republic, the main discussion on modern Turkey has been centered on the place of religion (representing the Ottoman past in its entirety) in the new era. Founding fathers identified religion as a traditional institution that functioned as cultural baggage or dead weight and was not part of the modern scientific imagination. Accordingly, they thought that traditional representatives of Islam would wither away because the process of westernization would bring with it positive developments such as economic progress, secularization, and enhancements in education, transportation and mass communication, all of which would somehow diminish the need for religion among the masses. ${ }^{8}$ For the founding fathers, the modern path involved the secularization of state and society devoid of any higher value system other than loyalty to the state through a new sense of Turkish national identity.Reforms were promulgated to create a new Turkish Republic as a break from the traditional Ottoman past.

Literature dealing with Islam and politics in Turkey followed the same reasoning, that Islam was cultural and historical baggage that had no place in the public domain of a modern, secular state. There are three main characteristics of this scholarship. First, it

\footnotetext{
${ }^{7}$ According to a survery done just before the 2002 elections, only $28 \%$ of Justice and Development Party supporters voted for a religious party [Erbakan's Parties] previously. For more see Vertigans 2003, 76.

${ }^{8}$ One of the famous representations of this commitment is found in Mustafa Kemal Ataturk's famous speech he gave in the city of Kastamonu in 1925. When he introduced his reforms involving new dress codes (prohibiting wearing traditional fez and turban) and closing the dervish lodges, he stated that "Republic of Turkey will not be a country of shaikhs [and] dervishes..."
} 
portrays religion as an anti-modern, anti western factor; secondly, they disregard the strong continuities between the late Ottoman and early republican eras, consequently portraying religion as an epiphenomenal factor belonging to the past, not the future. The arguments typical of this scholarship are represented by a handful of scholars who have saturated the discourse with essentialist analysis.

Unlike other parts of the Middle East, Turkey has attracted very limited attention from scholars working on Islam and politics, for two broad and basic reasons. First, for these scholars, modernization reforms were proving successful and secular Turkey was becoming more of Occidental than Muslim. This is an example of "value-laden" approaches in the social sciences. Pippin reminds us that modernization has a dual character that is manifest among the intelligentsia and within scholarship. These scholars, he argues, see the experience of modernization both as a process of historical transformation and, more importantly, as an adoption of a new "philosophical and civilizational ideal. ${ }^{9}$ The normative convictions of this philosophical and civilizational ideal result in the necessary (deliberate or not) misreading of the internal dynamics of an "other" (in this case Islam in Turkey). The consequence of cultivating a dualistic reading of world affairs based upon imaginary others is total: it reduces socio-cultural and historical analysis into irrelevant representations where certain key assumptions about cultural superiority are taken for granted.

Secondly, for decades Islamic studies in western institutions produced very few scholars on Turkey; often Arabic and Persian were prioritized over Turkish and the main

${ }^{9}$ Pippin 1997; Houston 2004, 49-69. 
research questions were asked in reference to classical issues in Muslim history such as the life of the Prophet, theology, and law. For them there was, certainly, another important technical problem about studying Turkish; scholars had to learn two entirely different alphabets (and in some cases grammars) to master in one language. First, they had to learn Turkish with Ottoman paleography and then the modern Turkish in Latin script. One of the major exceptions in the field is Bernard Lewis who is competent in both "old" and "new" Turkish. ${ }^{10}$ For a long time his ideas have near monopoly on the role and place of Islam in Turkey. In his translation of Turkish scholar Fuad Koprulu's "Islam in Anatolia after Turkish Invasion" (originally printed in 1922 in Turkish in the original Ottoman alphabet), Gary Leiser states that this major contribution by Koprulu (whom Leiser calls the "founder of the study of the religious history of the Turks in the entire Middle East") "was virtually lost to the scholarly world, including to some degree Turkey" because it was not accessible to scholars who did not know the Ottoman Turkish language. According to Leiser, "only a handful of Western scholars, such as H. A. R. Gibb, Harold Bowen, Bernard Lewis, and Speros Vrynois, have known of this work and used it."11

Bernard Lewis's main argument is straightforward. He argued that the establishment of the republic was a clear rupture from the Islamic past into a modern, westernized future. ${ }^{12}$ For Lewis, in every era of history modernity has been the standards

\footnotetext{
${ }^{10}$ For an interview-article in which Lewis demonstrates mastery of Ottoman and modern Turkish see "Turkiye'nin gelecegi icin bedbin degilim bilakis nikbinim" (I am not pessimistic but optimistic about Turkey's future) see Zaman Newspaper September 27, 1998.

${ }^{11}$ Leiser's translation is published in 1993. Koprulu 1993, xviii.

${ }^{12}$ Lewis 2002 [1961].
} 
of the dominant civilizations. ${ }^{13}$ The idea of the emergence of a new, modern Turkey represents the optimism inherent in the notion that the past, being religious, was unproductive and outdated, whereas a secular future promised endless opportunities.

Bernard Lewis has adopted the elitist view that the autocratic and traditional Ottoman Empire collapsed and was replaced, as if by destiny, by a modern, secular democratic Republic. ${ }^{14}$ The Kemalist reform program is not considered by Lewis as irreligious; its purpose was not to destroy Islam, but to disestablish it - to end the power of religion and its exponents in political, social, and cultural affairs, and limit it to matters of belief and worship. In this Kemalists were on the side of history in reducing Islam to the role of religion to the private phere. In a modern, Western, nation-state, religion only has public utility if it is in the service of national unity or the ideological legitimacy of the state. ${ }^{15}$ In his main study of Turkey Lewis portrayed the Republican elite headed by Kemal Atatürk as national saviors against a backward religious tradition (Islam). The narrative put forward by Lewis gives the secularist establishment inaugurated by Ataturk positive moral status, vis-à-vis Islamist actors. More recently, Samuel Huntington's article "Clash of Civilizations," 16 solidified this scholarship by constructing an enemy

${ }^{13}$ Lewis 1997, 129.

${ }^{14}$ Lewis 2002 [1961]; Davison 1998, 87.

${ }^{15}$ Lewis 2002 [1961], 406.

${ }^{16}$ Huntington 1993. Basically, Huntington's thesis is based on Lewis' scholarship, 1990. Subtitle of Lewis's article is very telling; "Why so many Muslims deeply resent the West, and why their bitterness will not easily be mollified." 
bent on violent warfare with the United States and other western countries on the bases of cultural differences. ${ }^{17}$

Other scholars on Turkish Islam who share the same ideas as Lewis are Tarik Zafer Tunaya, ${ }^{18}$ Niyazi Berkes ${ }^{19}$ and Feroz Ahmad. ${ }^{20}$ Tarik Zafer Tunaya was one of the earliest scholars to address the role of Islamism in Turkey as an anti-modern factor. He argued that, against the anti-modern positions of Islamic social movements, the Kemalist state introduced a progressive secularism that successfully actualized modernity. ${ }^{21}$ According to essentialist scholars like him, there is a constant struggle between modernity and tradition in the Muslim world and in Turkey; while secularism is the jewel of a modern life-style, traditions based on Islam are relics of the past and are only impediments to participation in the modern world. ${ }^{22}$ These scholars saw continuity only in the sense of traditional past trying to plague the modern present. ${ }^{23}$

The "Turkish Model" literature follows the same kind of reasoning. It argues that the Kemalist experience in Turkey is a unique example where a traditional society was finally able to transform its backward status to achieve the pinnacle of success by

\footnotetext{
${ }^{17}$ Hall and Jackson state that Huntington's thesis “... has attracted an enormous amount of attention, both for its simplicity in dividing the world into mutually exclusive communities characterized by deep-essential differences, and for its pessimistic conclusion that these differences are so fundamental as to make the communities in question more or less implacably opposed to one another." Hall and Jackson 2007, 1-15.

${ }^{18}$ Tunaya 2003 (originally published in 1962).

${ }^{19}$ Berkes 1998 (originally published in 1964).

${ }^{20}$ Ahmad 1993.

${ }^{21}$ For more see Tunaya 2003.

${ }^{22}$ The same essentialist views on Islam in general are also represented by Tibi 2002.

${ }^{23}$ Tunaya 2003, 129.
} 
becoming, quite generically, modern. ${ }^{24}$ The Kemalist model is not only a key example used in scholarly writings but also a paradigm emulated by authoritarian regimes of the Muslim Middle East. No country following the Kemalist model, however, is or has been able to accommodate Islamic groups or religious concerns into the political system. Prerevolution Iran and Nasr's Egypt are prime examples. ${ }^{25}$

Recently, a new generation of scholars has begun to voice arguments against the dominance of essentialist ideas in the discussion of Islam and modernity. Contrary to the Turkish Model argument Zurcher, for example, argued that the early republican era was so authoritarian that there was a huge chasm between the government and the people because the demands of the marginalized and relatively helpless sectors of society were never represented in state policy. ${ }^{26}$ For him the authoritarian nature of the Ottoman government was transferred into the republican era by the leading elite who were part of the major late Ottoman secular political party of Committee of Union and Progress. Yavuz considered this process to be draconian measures aimed at eliminating Islam from the public sphere. ${ }^{27}$

In Zürcher's words the reform process to separate Islam's influence in education, politics, and daily life was an attempt to separate Turkey's link with its Middle East neighbors by de-emphasizing Turkey's Ottoman past and its historical, cultural and

\footnotetext{
${ }^{24}$ Mango 1993; Heper 1997. The Turkish Model thesis has been criticized by Altunisik 2005.

${ }^{25}$ Sayyid reads modernization projects in the Middle East from a Kemalist project perspective. Sayyid 2003, 69-72.

${ }^{26}$ Zürcher 2003.

${ }^{27}$ Yavuz 2000 .
} 
religious links to the Middle East. ${ }^{28}$ Zürcher has drawn attention to Lewis's scholarly bias. Based on archival evidence he has demonstrated that the late Ottoman period was full of Muslim reformist thinkers who accepted the possibility of having mutually beneficial cultural and intellectual exchanges with western nations. ${ }^{29}$

This new generation of scholars was able to re-read the uncontested definitions and explanations of the previous generation of essentialist scholars. The new generation of scholars argued that the main weakness in essentialist approaches is that it seeks to explain complex social events by reducing them "to a few "essential" causes." 30 For essentialists the current condition of the Islamic world is a result of Islam and Muslims themselves. Islam is identified as the source of Muslim inferiority vis-à-vis the secular west, which produced and embodies the secular paradigm.

One of the main methodological and theoretical criticisms of essentialist scholarship is that it ignores the diversity in principles and ideological orientations of Islamic movements in Turkey. This is based on the Constructivist premise that identities are not given but constructed. Therefore, Huntington's work is problematic because it depends on an uncritical and passive readership to accept that Islam is a monolithic entity. ${ }^{31}$ We can argue that, the fundamental assumptions of all of dominant perspectives within the literature are based on the same premises. According to these explanations,

\footnotetext{
${ }^{28}$ Zürcher 2003, 196-200.

${ }^{29}$ Besides Zürcher others have argued that the Kemalist project had its sources in late Ottoman era developments. For more see Mardin 1989, Özbudun 1996 and more recently Heper 2000.

${ }^{30}$ Yavuz 2003, 16.

${ }^{31}$ Kubálková 2003, 93.
} 
first, Islamic principles are essentially irreconcilable with dominant western principles like democracy, human rights and freedom. These explanations consider Islamic values to be antithetical to the humanist values of the West; therefore, there cannot be a prowestern, modern, democratic Islam. ${ }^{32}$ Second, it is only possible to have a moderate and democratic Islam if there are strict secular controls over it. ${ }^{33}$

Conventional scholarship argues that it is not a moderate reading of Islam that leads to a peaceful and tolerant vision of the world among Islamists, but strict secularist measures that socialize Islamic groups into a kind of passivity that softens their inherent inclination towards conflict. This argument, in simplified terms, asserts that it is not possible to have a moderate Islam unless we de-Islamize it. One must first reorient the Islamic gaze from the sacred realm to the secular world and then use Islamic language and symbols to legitimize the secular order. ${ }^{34}$ It is a vision of Islam that is completely domesticated and subordinate to secularism in Turkey. This argument gives token acceptance to Islam as a tool for group identification and mobilization while dismissing the possibility of different implications the Islamic worldview would have for the style and substance of domestic politics.

Among Turkish scholars important critiques of Lewis' scholarship were produced mostly by Turkish scholars living in the West. Most of the time, due to government scrutiny, scholars were not able express their ideas and were often pressured by

\footnotetext{
${ }^{32}$ Erdogan, a constitutional law professor and no relation to the Prime Minister Erdogan, has been one of the most ardent critics of this understanding. Erdogan 1999.

${ }^{33}$ Sayyid 2003.

${ }^{34}$ Davison 2003 discusses the secular policies of the Turkish state.
} 
government officials or 'academics' connected with government officials. Serif Mardin can be considered in this vein. His analyses were based on interpreting religion as continuity rather than historical baggage. ${ }^{35} \mathrm{He}$ consistently rejected the study of Islam as a new phenomenon. ${ }^{36}$ A recent controversy happened when the Turkish Academy of Sciences denied the membership application of Serif Mardin because his books on Islam criticized the secular reading of Islam in Turkey. ${ }^{37}$

The Islamic world is made up of a mosaic of different races, cultures and histories; it is impossible to speak of one Islamic identity. From Morocco to Indonesia, there are over fifty countries with different political and economic systems, histories, languages and cultures, all of which share the same fundamental religious tenets. ${ }^{38}$ Scholarly works that focus on particular Islamic cases must be contextualized within that specificity so that universal ideas about the nature of Islamic socio-political activism do not distort reality. However, individual cases are used to develop universal explanations that are applicable for the entire Muslim world and Islamic political identities. ${ }^{39}$

Most of the movements that are dealt with in academic studies are revolutionary political movements that had resorted to violence as a form of political expression. Universalizing the nature of the relationship between Islam and politics or the place of Islam within a state has been reduced to fundamentalist and anti-western movements.

\footnotetext{
${ }^{35}$ Mardin's book on Nursi is a major example. For more see Mardin 1989.

${ }^{36}$ Cigdem 2005, 33-34.

37 “Kemalist Bilim Anlayisi” (Kemalist Coception of Science) Sabah July 7, 2007.

${ }^{38}$ Ahmet Kuru's recent work shows the differences not only between the western world and the Islamic but also within the Islamic world. Kuru 2009.

${ }^{39}$ Gole 1996; Gole 2000.
} 
Theorizing based on the actions of a limited number of movements in more strategically placed areas, such as the oil rich Persian Gulf, does not contribute to our knowledge or ability to understand Turkey. In these studies individuals as agents of change are ignored altogether. ${ }^{40}$

There are different manifestations of Islamic activism that have yet to be articulated in the mainstream literature. Contrary to the monolithic and unitary portrayals of Islamic movements common in western media and academia, a deeper analysis of Islamic social movements suggests that they are substantially more plural and flexible than conventional studies presume. In order to understand the internal dynamics of Turkish Islamic movements this study utilizes a qualitative interpretive methodology. By examining the historical development of the distinct religious communities and their attitudes towards important religious and political issues involving the West and the secular state, this study will shed light on the existence of diverse Islamic identities which were long absent in the conventional studies.

There are differences within the overall Constructivist approach to the relationship between actors and their environments (agent-structure debate) in identity formation process. In this work, I tried to utilize a framework that does not overtheorize structure over agency. This does not necessarily mean disregarding the role of structure over the agent. However, structural explanations cannot adequately understand the selfreferential if not dogmatic identities of the religious actors that constantly challenge the structural limitations around them. Mesbahi argues even Constructivists, who see social

\footnotetext{
${ }^{40}$ Saktanber analyzes individual Muslim actors constructing Islamic identity. Saktanber 2002; Kandiyotu and Saktanber 2002.
} 
relations as a "co-constitutive" process, often omit the qualities that come from actor's own imaginings and interpretations which are formulated independent of social relations, from reading a religious text. ${ }^{41}$

I argue that the plurality of Islam in Turkey is represented by three interconnected yet distinct Islamic approaches. They are Shariah, Tariqah and Haqiqah. Although these Islamic approaches represent distinctive aspects of Islamic life and thought, they are not closed entities. They are all on the same page in terms of their main creedal tenets while also disagreeing on some critical issues. On the other hand, although these three approaches have substantial influence on the AK Party, it is neither a direct continuity nor independent of any Islamic movement. AK Party is made up of politicians coming from different religious (also secular) backgrounds. Its principles are an amalgam of conservative $^{42}$ cultural expressions together with the ideals of independent Muslim thinkers in the country; Neo-Ottomanism can be a useful term to define it.

In the following theoretical chapter, I summarize the main questions followed by a representation of the method preferred for this study in examining the relationship between three Islamic approaches represented by the Hadith of Gabriel and Justice and Development Party's Neo-Ottomanism. The following three case study chapters will be devoted to each one of the grassroot Islamic movements in Turkey. The third chapter introduces the influential Naqshbandi Order. The fourth chapter deals with the Nur Movement and its Gülen offshoot. The fifth chapter examines the Islamist-National View

\footnotetext{
${ }^{41}$ Mohiaddin Mesbahi, Fall 2002 class notes from "Seminar on Islam in International Relations" about power and limitations of Constructivism in understanding Islamic agency.

${ }^{42}$ Kilinc utilizes "Conservatism" to understand Abdulhamid II era Ottoman policies. For more see Kilinc 2002.
} 
Movement that has done the most to develop the idea of political Islam in the modern Turkish consciousness. In this chapter, the narrative of the separation of the National View Movement and Justice and Development Party will be examined. In chapter six, I analyze how these three Islamic movements influenced Justice and Development Party. This chapter traces the current Islamic government's foreign policy choices to the Islamic method they emulate. The conclusion reviews the case studies and the resulting theoretical implications, focusing on the trajectory of relevant political issues.

For this study, different sources were consulted. In terms of examining the histories of these movements, primary and secondary sources in Turkish have been utilized. These sources include the texts published by the leaders of these Islamic movements, their diaries, and important interviews. In terms of understanding the members of these organizations through personal interaction, I attended public and private events as an observer. Surprisingly, United States is also home to many members of these Islamic communities and their leading figures. I met with politicians (Minister of Education of the Justice and Development Party), mayors (first elected mayor of Islamist Welfare Party), government bureaucrats (in charge of auditing the Turkish schools abroad), leaders of Islamic groups (such as an American Naqshbandi Shaikh in Tucson, Arizona who received his Islamic studies diploma from the Naqshbandi order in Turkey), members of the Turkish Naqshbandi students in North America in their annual 2006 gathering; immediate students of Fethullah Gülen (leader of the prominent Gülen Movement); and the leaders of other Islamic groups including but not limited to Mustafa İslamoğlu, and Faruk Celebi, the leader of the RumiMevlevi order who currently resides in Miami, FL. 
Research in Turkey also produced rewarding data. In 2006, I visited important places that allowed me to gather more data about the National View, Nur and Naqshbandi movements. Specifically, in October 2006, I visited cities of Burdur and Isparta, where the Nur movement first began and later flourished. Especially in Isparta, my visit to "Nur houses" where Said Nursi lived was very helpful in understanding the dynamics of the Nur community firsthand. In November of 2006, I went to Ankara where I visited institutions established by people inspired by the ideas of Fethullah Gülen. These visits continued in Istanbul in late November, mostly to Naqshbandi institutions, in Fatih-Çarsamba, a town famous for its Naqshbandi residents and leaders. 


\section{Chapter II: THREE ISLAMIC APPROACHES IN TURKEY}

This chapter deals with the normative foundations for Islamic belief, practice, and identity. The source that I will use to draw out the parameters of normative Islam is the Hadith of Gabriel. In this hadith, various modes of Islamic life and practice are presented and serve as the basis of a typology of Turkish Islamic actors. This specific typology has never been utilized in other studies analyzing Islam and politics, especially those focused on the interplay between Islam as a religion in a modern world and Islam as a political ideology. ${ }^{43}$ The Turkish case is not an exception.

Once we are able to identify the distinct qualities and differences between various cultural manifestations of Islam it becomes clear that there is no monolithic expression of Islamic political identity. Employing the Hadith of Gabriel in my analysis of Islam in Turkey will enable me to further explore the sources of pluralism among and between Muslims in Turkey; this will enable me to present an overall framework in which classify and identify Islamic political actors based on a system of thought and representation that is natural to them. The implications of this, which will become clear as this study progresses, is that the Justice and Development Party cannot be understood through rigid terminological identifications (like an us-them dichotomy, anti-westernism, political authoritarianism or taqiyya) which have been applied to other Islamic groups in the Middle East. On the other hand this typology is capable of accommodating a wide range of actors, from the most radical to the more or less pacifistic. In this way, theorizing about Islamists will not impose on them certain characteristics that are only found in

\footnotetext{
${ }^{43}$ One of the earliest attempts of utilising the Hadith of Gabriel in analyzing Islam is by Martin Lings in
} Lings 1961, 45. See also Chittick 1992, 2-6 and more importantly Murata and Chittick 2006 [1994]. 
other groups labeled Islamic; their specificity is therefore maintained. In the Turkish case, there are various modes of being within Islam which are hierarchically outlined through the Hadith of Gabriel; the AK Party's Neo-Ottomanism is not free from different modes of Islam.

A common theme in the literature about Turkish politics from the beginning of the $20^{\text {th }}$ century has been a misapprehension of Muslim revivalist movements and their critical position vis-à-vis Westernization. Revivalists attributed the backwardness of the Muslim community, directly or indirectly, to the abandonment of Islamic religious faith and practice. ${ }^{44}$ The Naqshbandis were one such movement in Turkey. Because of their organizational superiority over rival orders (tariqahs), and their status as representatives of orthodox Sunni Islam, they were able to spread quickly and become a major religious movement that has unsettled relations with the state. Scholars view the role of the Naqshbandi order in protest against westernization as foundational. ${ }^{45}$ They were the first major critics of secular reforms in Turkey during the late Ottoman era. They did not see the secular reforms of the state, backed by the western powers, as a viable solution to what were, for them, domestic problems. ${ }^{46}$ Yet these studies did not to recognize the fact that Naqshbandis were an umbrella tariqah for Turkish Muslims wherein different sub groups had developed different responses towards the modern questions.

\footnotetext{
${ }^{44}$ Haddad and Voll 1999; Kara 2001.

${ }^{45}$ Ahmad 1991.

${ }^{46}$ Aral, among others, states that westernization is an elite-backed reform process, Aral 2007. Davutoglu explains the consequences of the gap between the elite and the masses by referring to R.D. Laing's The Divided Self. Davutoglu 2002, 59.
} 
Turkish Muslim attitudes towards "others," including the secular state apparatus and Western powers, has been more complex than most studies will lead one to believe. Now, contrary to the dominant trends in identity theories, the relationship between the Muslim Self and the non-Muslim Other is not limited to the boundaries of a "self-other" dichotomy. ${ }^{47}$ The existing literature on this issue gives an inordinate amount of credit to imaginary constructs in the formation of identity because, naturally enough, any actor has to pay attention to their environment and existing power structures. However, structural factors should only be seen as environmental factors that affect choices and opportunities rather than strict limitations on Islamic actors and groups. Due to strong connections with normative sources, Islamic actors do not act like 'billard balls'; rather they are thinking agents following deliberate policies in line with their identities, interests and goals.

Contrary to Western concepts of religion, Islam functions as a system of values where identity is not a product of social relations, but of faith. ${ }^{48}$ As a religious belief, its value system comes not from the social life but outside of it. ${ }^{49}$ For Muslims, this comes from the traditional sources of Islam: the Quran and the Hadith. Both of these sources

${ }^{47}$ Fore more on alternative explanations of identity formation see Hopf 2002, 1-38.

${ }^{48}$ Serif Mardin's contribution to the study of Islam has been his unique approach in analyzing Islam on its own terms. For his description of Islamic identity, inter alia, see Mardin's articles collected in Mardin 2005 and especially page 271. Ahmet Davutoglu, the current Minister of Foreign Affairs of Turkey who was instrumental in shaping Justice and Development Party's foreign policy is, interestingly enough, a student of Serif Mardin. In Davutoglu's own formulation, Islamic identity is self-referential. He prefers to use 'selfconcept' to 'identity' and argues that identity is based on social recognition and requires two parties while self-concept represents individual consciousness that does not require/need social recognition. In Davutoglu's explanation policy making process can change because it relies on identity while orientation of identity does not change because it relies on self-concept. Davutoglu 1997, 11.

${ }^{49}$ I follow Geertz's explanation: "the major characteristic of religious beliefs as opposed to other sorts of beliefs ... is that they are regarded as being not conclusions from experience...but as being prior to it. For those who hold them, religious beliefs are not inductive, they are paradigmatic; the world... provides not evidences for their thruth but illustrations of it. They are a light cast upon human life from somewhere outside it." Geertz 1968, 98-99. 
deal with the history of the early Muslim community and the prophethood of Muhammad. Therefore, in explaining specific Islamic understandings while the external environment is an important factor in the formation of identity, the references of various Muslim actors within Islamic discourse deserves primacy of place in the study about Muslim self-concept.

Major Islamic movements in Turkey mentioned here are the Naqshbandi, National View, and the Nur-Gülen movements. The National View and Nur-Gülen movements are both offshoots of the Naqshbandi tariqah. Although these major Islamic movements are all on the same page when it comes to the creedal tenets, they have articulated plural images of their individual identities, the secular Turkish state, the place of Turkey in the world and its relations with the West. When Turkey began its bid for European Union membership some major Muslim communities were suspicious of EU membership. For them EU's imperialism was not for the good of the Muslim population. The Naqshbandis argued that this course would have devastating effects on the Islamic culture in the country. ${ }^{50}$ National View's leader, Erbakan, argued that the EU was a Christian institution, and was therefore unable to accommodate Turkey. He argued that Turkey must establish a union with Islamic nations. ${ }^{51}$ On the other hand, decades before Turkey's European bid, in the 1930s, at the beginning of the Europe-inspired authoritarian regime in Turkey, the Nur Movement's leader, Said Nursi, supported the

\footnotetext{
${ }^{50}$ Mardin 1991.

${ }^{51}$ Some of Erbakan's projects were a United Nation of the Islamic countries, the establishment of an Islamic common market, the introduction of a common Islamic currency, a joint Islamic defence force, and, the establishment by the Islamic countries of a cultural cooperation organization. Erbakan 1971; Kamrava 1998, 279; Mecham 2004. Aral 2005 has a more moderate view on Turkey's relations with Muslim countries during the Erbakan era.
} 
idea of Muslim and Christian nations forming strong ties ${ }^{52}$ and foresaw a better and closer relations between the Turks and Europeans. Later during the 1990s, Fethullah Gülen, rooted in the Nur movement, argued that there were few legitimate or urgent concerns on the question of EU membership, provided Turkey was self-confident in its [Muslim] identity. ${ }^{53}$ The various responses of Turkish Muslims to the same "others" and environmental constraints defy simplistic representation because the reaction and response of different leaders were studied attempts on their part from within the individual expressions of Islamic approaches these movements adhere to.

To understand the plurality of of Islamic understandings and their representation in the Justice and Development Party's policies we need to study the major Islamic movements and the Justice and Development Party's relations with them. I argue that there are three modes of Islamic approaches in Turkey. The first Islamic approach is Shariah (Seriat). Shariah is the outward interpretation of religion and its enforcement over the society by means of a state apparatus. The second approach is Tariqah (Tarikat). Tariqah signifies religion as the practice of particular established norms within religious orders; it is the progressive internalization of the basic articles of faith. The third

\footnotetext{
${ }^{52}$ Nursi's argument is relatively strong. He argues that Christians and Muslims have common enemies against which they should form an alliance. Nursi's legal justification is a sound Hadith (saying of Muhammad), Nursi 1996, 663.

53 Pashayan 2007. Besides, earlier nationalist-Islamist scholars like Erol Gungor who wrote on the contemporary issues of the Islamic world argued that the Muslim world's perception of the West could not be described as an enemy/other relationship. For him, not the Islamic world but the western perceptions and consequent domination attempts made the relations worse. He argued that during the Cold War, Muslims sided with the Christian West against Communist Russia; therefore, the real Western perception of enmity against the Muslims did not come to the surface until the end of the Cold War. Gungor 1996. Similarly, Hakan Yavuz argues that Turkish Islamic movements were pro-western during the Cold War, although they had suspicions about its imperialist aspirations, Yavuz 2004, 222.
} 
approach is Haqiqah (Hakikat). It symbolizes religion as a form of spiritual journey based on the self's connectedness with God.

While this study utilizes religious terminology to explain the variations in Islamic practice in Turkish politics from the late Ottoman period, the normative connotations of Shariah, Tariqah, and Haqiqah are based on the classical sources of Islamic tradition. The references to Islamic sources considered authentic by the Muslims will enable me to examine Islamic movements in their own understandings rather than employing an incompatible typology that might not adequately address the diversity among them. The operative text that demonstrates this gradation in religious practice is popularly known as the Hadith (tradition) of Gabriel. Many Muslims and Islamic scholars consider this hadith as authentic. More importantly, this hadith defines and demarcates different Islamic understandings and is accepted by the Turkish Islamic movements studied in this work. I will cite the text in full:

On the authority of 'Umar who said: While we were one day sitting with the messenger of Allah (Muhammad) there appeared before us a man dressed in extremely white clothes and with very black hair. No traces of journeying were visible on him, and none of us knew him. He sat down close by the Prophet, rested his knees against his, put his palms on his thighs, and said, "O Muhammad! Inform me about Islam." The messenger of Allah said, "Islam is that you should testify that there is no deity save Allah and that Muhammad is His messenger, that you should perform salat (ritual prayer), pay the zakat (alms), fast during Ramadan, and go on Hajj"... He [Gabriel] said, "You have spoken truly."... He went on to say, "Inform me about Iman (faith)." [Prophet Muhammad] answered, "It is that you believe in Allah and His angels and His books and His messengers and in the Last Day, and in qadr (predestination), both in its good and in its evil." The man said, "You have spoken truly." Then he said, "Inform me about Ihsan (literally doing what is good, beautiful)". He (Prophet Muhammad) answered, "It is that you should serve Allah as though you could see Him, for though you cannot see Him yet He sees you... Then he [Gabriel] left and I stayed for a time. Then He [Prophet Muhammad] said: "O 'Umar, do you know who the questioner was?" I 
said, "Allah and His messenger know best". He said, "He was Gabriel, who came to you to teach you your religion." 54

This tradition fits neatly into the tripartite division of Turkish Islamism noted above. The shariah (Islam in the Hadith) approach is the most basic, broadly based, and widely discussed in the literature about the Muslim world. It is relevant to nominal identity in its most basic form as well as to issues of law and order and personal behavior. The outward and basic interpretation of the religion requires enforcement over the society by means of a state apparatus. In its basic meaning Islam here means submission. The Quranic response to the Bedouins who say "We have faith" is "Say [O Muhammad!]: You do not have faith; rather say, 'We have submitted;' for faith has not entered your hearts." ${ }^{55}$ In the shariah-based approach the Quran, sunna of the prophet Muhammad (the normative practice) and the sources of law that are not based on direct texts but derive from a legal methodology which utilized the Quran and traditions of the prophet Muhammad need to be implemented in society through state institutions. This narrow aspect of Islam, popularly known as Shariah, is the most popular one among Islamist political movements for whom religion is a law meant to be implemented coercively. As will be discussed in the Islamist National View Movement chapter, Sharia has become the most important aspect of Islam for movements involved in active political life.

Tariqah approach is the complete and steadfast identification of the believer with the basic theological propositions of Iman (faith) as universal moral values. For the Turkish Naqshbandis, tariqah meant a specific method that involved spiritual, ethical and

\footnotetext{
${ }^{54}$ Nawawi 1996, 3-5.

${ }^{55}$ Quran 49:14. Because it focuses exclusively on the political realm, Chittick considers this as the narrowest meaning of Islam, Chittick 1992, 3.
} 
social principles in order to perfect the soul of the believer under the strict auspices of a leader (Murshid or Kamil Murshid). The most important aspect of this 'perfection process' is that it should be implemented in and around a Sufi center (tekke and zaviye) where tariqah members live a highly interconnected life. ${ }^{56}$ An Iman-informed approach to modern politics would question the absolute premises upon which secularism establishes itself as normative. An imagination of life lived according to the principles of God is considered as the most important aspect of Tariqah. ${ }^{57}$ Issues relevant to Turkish politics that would be addressed by this approach are corruption, the importance of family values, and issues of practicing religion in social life according to a strict adherence to tradition.

The last approach, herein labeled Haqiqah, is based upon the spiritual principle (Ihsan in the Hadith) that when the Muslim is in a state of prayer he should be wholly attentive to the object of prayer, $\operatorname{God}^{58}$ rather than worldly objects. This is an ideal spiritual station where individual believers can ascertain the quality of their own worship by going beyond the surface of practicing religion and entering into the spiritual depth of religious conscious. ${ }^{59}$ This requires a self-controlled religious practice that does not require an apparatus to control and promote practice of religion other than voluntary joining; it is a theology of anti-institutionalism. Therefore, its application in (Turkish)

\footnotetext{
${ }^{56}$ Gunduz 1984, 169-170.

${ }^{57}$ Turkish Naqshbandi leader Kotku argues that this is the main reason why Tariqahs emerged in the Muslim world. Kotku 1984, 16-17.

${ }^{58}$ In ihsan tradition masiva means "things other than God." For an example of masiva in ihsan tradition of Nursi (and Gülen) see Nursi 1996, 220.

${ }^{59}$ Chittick 1992, 5.
} 
politics, and at a general level of Islamic politics, is a bit problematic. How does one know if the Justice and Development Party is in a state of Ihsan? That determination will be based upon two interrelated factors: the level of emphasis which the party (in contradiction to an Islamist regime or the Erbakan government) places on the state as the agent of Islamic values, and the substantive policy principles of the party.

In their origins, these three Islamic approaches stemmed from the centuries old tradition of the Naqshbandi orders. Naqshbandi orders have been a major Islamic social movement of religious expression in Turkey. The primacy of the Naqshbandi order in the social and political life of Turkey runs generally uninterrupted throughout the history of the Turkish presence in Anatolia. ${ }^{60}$ This is incomparable in the rest of the Muslim World. It is therefore imperative to analyze the Naqshbandi tradition and its transformation over time. The most important aspect of the Naqshbandi message has been the reformist nature of the order; the leadership was cognizant of the rising power of the state apparatus and constantly developed new methods of religious interpretation so that they could address the challenges of rising political and ideological threats. However, over time different members of the Naqshbandi order developed variant interpretations of the original Naqshbandi message based on their own intellectual inclinations and personal aspirations.

This study does not reject the possible material or ideological impacts of the nonTurkish Islamic influences coming from the rest of the Muslim Middle East. Non-Turkish Islamic reactions to the secular modernization process has manifested in a radical

${ }^{60}$ Esposito 2001. 
withdrawal from the secular state apparatus. However, in Turkey the reaction of the Naqshbandi order was different. Instead of being confrontational, the Naqshbandis preferred to resist the coercive methods of the secular state via pacifist means. This unique approach is characteristic of all major Turkish Islamic movements who were able to preserve their religious identities without threatening the secular state. The personal and organizational space created by their focus on teaching Islam through social channels and redressing injustices through civil society activism and political lobbying via apolitical means contributed to their success and added credibility to their future political program. The rich and established tradition of the Naqshbandi order in Turkey did not import methods from other Muslim and non-Muslim experiences. It was a product of an indigenous tradition of Islam. First, in order to promote their message among the people, the Naqshbandis already knew how to deal with oppressive governments based on their centuries old experience with various political apparatus's.

Second, and more importantly, the centrality of the Caliphate in the hands of the Ottomans for centuries created a self-perpetuating Ottoman identity. As an Islamic tradition, the idea of state as equal to the religion itself experienced its peak during the Ottoman era. ${ }^{61}$ Therefore, socio-political and cultural relationships between Islam in Turkey and rest of the Middle East were mostly one directional: from the Caliphal core to the periphery.

Naqshbandi approach as the main religious demographic in Turkey did not approve of violence or openly confrontational policies towards the state. This does not

${ }^{61}$ Sayyid 2003; Berkes 1998, 13-14. Kaplan examines the pre-republic era din-u devlet understanding (unification of religion and the state) and its incorporation into the republican era textbooks. For more see Kaplan 2002. 
necessarily mean that other religious movements followed the exact same method. Many Islamic actors interpreted their own selves and the structure around them differently. This led to different guiding principles and strategies among the representatives of Islam in Turkey. The way different Islamic groups reacted to new environmental conditions demonstrate to us the different internal dynamics (or identities) these actors developed over time.

An important example would be the influence of scholars like Sayyid Qutb, Ali Shariati, and the occurrence of the Iranian revolution on the National View Movement. ${ }^{62}$ The National View movement has politically been the most critical voice against the secular state and the West. Necmettin Erbakan founded and provided leadership to the movement from the early seventies. The National View movement's cultural orientation can be identified with the Shariah approach. They are especially prone to the ideological uses of "otherness" with Islamic symbols and terminology to understand the self and the other. However, as the National View Movement leadership attempted to implement methods reminiscent of Qutb's ideas or those of Iranian revolution involving street protests, the religious wing of the organization denounced it and distanced themselves from National View Movement's political activities. ${ }^{63}$ In this way, the anti-modernist message of Qutb and others lost their appeal with the grass-roots Naqshbandi-Sufi tradition. The National View Movement became the sole representative of the Shariah approach in the political arena. It was interested in implementing Islamic religious laws through the state apparatus. It tried to institutionalize Islam within the state's law-making

\footnotetext{
${ }^{62}$ Daği explains the non-Turkish Islamic influence on the National View Movement. For more Daği 1998.

${ }^{63}$ Yasar 2004.
} 
and enforcement structure. In this movement, control of the State via the political process has been the primary goal. This Islamic approach emphasizes the state as the primary instrument of Islamization of society.

The understanding that makes up the Naqshbandi tariqah is founded on the traditional understandings that emerged in a sacred past that are not necessarily open to change and flexibility. It is based on the theological principles enunciated in the hadith of Gabriel: the reality of God as Lord over the world, the importance of prophets and their scriptures as divine sources of guidance, and elements of the unseen such as angelology and predestination. Tariqah emphasizes the spiritual development of individuals and religious communities via the voluntary practice of the Sunna (normative deeds of the prophet Muhammad); these traditional methods have been reinforced within the tariqah system over the centuries. The Naqshbandi order's Tariqah path is a moderate one in between the Shariah and Haqiqah approaches. Tariqah approach is consistently "other cautious" but does not necessarily try to create "enemy others" on a constant basis like the National View Movement. It distinguishes between its vision of Islam and different worldviews they see as innovation. But the driving force or motivation among the tariqah actors does not depend on political adversaries to be combated. Their focus is on the social community.

On the other side of the spectrum lies the Nur movement, which has consistently viewed the state as an institution that provides security rather than cultural identity. In the Nur community, the dominant Islamic approach is the "Haqiqah" Islam, which has a more or less "other-less" Islamic understanding that focuses on the self rather than the other. Its main point of reference is the tradition itself connecting believers to the Divine 
Truth (Haqiqah) and the believer as agent of tradition. This is a self referential-identity that is not spoken of in the scholarship. Nur community, as it is represented in the hadith of Gabriel, emphasizes worshipping God as if they could see him. In their religious psychology, nothing happens independent of the will of God. Therefore, they do not (one could argue that they are unable to) devote energy in constructing an "other," but are in constant dialogue with God through individual worship. ${ }^{64}$

The Nur (the Light, understood in a spiritual sense) movement of Said Nursi ${ }^{65}$, and most recently Fethullah Gülen, ${ }^{66}$ give primacy to belief in the Oneness of God. Belief in God, the Nur community holds, is the first and foremost principle of an Islamic identity. For them, the concept of ihsan established the equality of all believers before God and motivates them to come together to encourage one another on the path of God. The believers are also united in their distrust and apprehension of a society without ethical or moral values grounded in belief in God. In that respect the main actor in Haqiqah approach is the individual believer struggling to accomplish his duty towards God over and above the spiritual distractions ubiquitous in a secular society. The person affected by and operating within the cultural sphere of haqiqah is focused on worshipping God with single-minded attention. Socially haqiqah is manifest in an ambiguous attitude

\footnotetext{
${ }^{64}$ Ihsan is described above: "It is that you should serve Allah as though you could see Him, for though you cannot see Him yet He sees you."

${ }^{65}$ Nursi 1996, 1277-1278. Nursi's entire body of work, including his biography, are compiled in Nursi 1996. Throughout this dissertation, this collection is consulted.

${ }^{66}$ Recently some major scholars began to focus on Nur and Gülen movements in Turkey. Abu-Rabi 2003; Yavuz and Esposito 2003.
} 
towards power. One does not seek power for its own sake; the focus is to promote the truths found in the tariqah path with minimal tension.

By looking at the relationship between the three major Islamic movements and the Justice and Development Party, I will embark on the rather understudied issue of contested identities of Islamic movements, their self-concepts, their perceptions of the West and their unique relationships with the state apparatus. In concrete terms, this involves how Islamic movements view themselves, how they view others and what is their vision about the Turkish state in the world. Therefore, the main topic of this study is centered on the special relationship between Islamic movements and the political system in Turkey. On the other hand, special attention to the Justice and Development Party government will show the limits of the influence of these three Islamic movements on the Justice and Development Party, which can at most be considered an indirect continuation of them.

In order to grasp the diversity within the Muslim world and the existence of different Islamic political identities one needs to analyze Islamic identities from within their changing environments where a reaction to the western world and the imposition of modern norms is just one issue addressed by Islamists. Few studies of political Islam, and the varied role of Islam in the modern world, are able to break out of this narrow focus. Serif Mardin is a scholar who has been able to transcend these discursive limitations. ${ }^{67}$ He argues that instead of focusing "on the differences in the role of religion as between 'Western' and 'Eastern' societies taken as polar opposites," we need to recapture "the

${ }^{67}$ Mardin 1989. 
internal spring of Islamic social structuring as a dynamic process." ${ }^{68}$ The internal spring of Islamic social structuring is rooted in a tradition of ambivalence to political power. The three distinct Islamic approaches (Shariah, Tariqah and Haqiqah) represent different approaches to the state, themselves, and sometimes imaginary others. Its simplest form is Shariah. ${ }^{69}$ Holy Law has cross-cultural and global implications for Muslims because it is "God's eternal and immutable will for humanity, as expressed in the Quran and Muhammad's example., ${ }^{, 70}$ But each actor discussed in this study practices Islam at a different level based on the hierarchy explicit in the hadith of Gabriel which stretch from political quiescence to accommodation.

\section{Political Quiescence and Accommodation}

The death of the prophet Muhammad brought about the major question of political authority in his absence. The major split between the partisans (Shi'a) of Ali and the Sunni school school of thought (ahl al-sunna wal jam'a) on political legitimacy. The Shi'a argued that the prophet Muhammad's caliph should be his closest relatives who represented his family and were a link in the chain of divine knowledge revealed to the prophet. The debate on the status of Muhammad's family (Ahl al Bayt) as trustees of his message is important because he did not have a male heir and his lineage was widely recognized to continue through the children of his daughter Fatima and Ali ibn Abu Talib. Prophetic traditions as well as the Quran support the superior status of

\footnotetext{
${ }^{68}$ Mardin 1991.

${ }^{69}$ Zubaida 2005.

${ }^{70}$ Esposito 2003.
} 
Muhammad's family. In addition, Muhammad had often praised Ali for his knowledge of religion and at times left him as the leader of the community in his absence. ${ }^{71}$

However, Ali was younger than Muhammad's immediate peers were and after his death, this older generation was able to win popular support and political legitimacy. ${ }^{72}$ Ali did not contest the leadership of his three immediate predecessors ${ }^{73}$ - though he did articulate the claim that his position as leader was usurped from him— because he did not want to create fitna, or civil violence and division, among the members of the burgeoning Muslim community. Ali eventually became the fourth caliph after Muhammad but immediately had to confront the politically active Umayyad family who had created positions of power for themselves within the political structure of the Muslim state in places like Syria and Egypt. The issue of the legitimate succession of the prophet as well as the status of his descendents in representing Islam is still a contentious issue and the subject of a scholarly discourse in its own right.

But this issue is also important for the majority Sunnis, who generally do not accept Shia claims about Ali and the ahl al-bayt. Within the early Islamic state individual believers implemented the Sharia in their personal lives, while the teachings of the prophet Muhammad were being transmitted orally. Scholars of law, the ulema, were prominent in their role as transmitters and proponents of Shariah. However, whose role was it to confer legitimacy, on specifically religious grounds, on the rulers of the Muslim

\footnotetext{
${ }^{71}$ See Madelung 1997. The author discusses the place of "the family of Muhammad" in the Islamic tradition.

${ }^{72}$ Madelung 1997, 1-27.

${ }^{73}$ During Uthman's caliphate, and right before his death, Ali tried to advise Uthman about the negative consequences of Uthman's so called nepotism.
} 
community? The religious classes were interested in promoting the practice of Islam and the recognition and institutionalization of sacred law. Some scholars may also have been motivated by personal ambition, but the point is that the avenue to Islamize society was by the law: the establishment, in legal form, and socialization of divine norms. The state in the early period of Islam, particularly the dynastic lineages that were developing, had as its interest what any power structure does: growth and survival. This resulted in a dichotomy between the reason d'être of the state and the divine will, as articulated by the scholarly classes.

Two social classes emerged: the ulema (the faqihs or recognized Islamic scholars of law), and the Sufis. ${ }^{74}$ The ulema tried to institutionalize their legal ideas through the state. ${ }^{75}$ The Sufi movement grew as a reaction to this legalistic if not secular approach to Islam. They focused attention on cultivating spirituality and distrusted the state because they did not want their faith to be corrupted by association with institutions of power. Within this dynamic lies the origin of Islamist relations with the state as the instrument of the divine will. ${ }^{76}$ For the greater part of Islamic history, political powers have been able

\footnotetext{
${ }^{74}$ Lapidus 1994, 253; Armstrong 2000.

${ }^{75}$ Lapidus identifies the ulema, especially in the Ottoman case, as "bureaucrats". For more see Lapidus 1994, 254.

${ }^{76}$ The peak of this process is the Iranian Revolution. Ayatollah Khomeini argued that the Islamic state, being the absolute trustee of the Prophet, has precedence over all other ordinances or religious practices. An important issue emerged in Iran about the distribution of land for administrative purposes. Some other Iranian clerics argued that because shariah protected private property and made no provision for the ruler to redistribute it, they argued, the state has no authority to regulate the issues protected by the contracts between the private parties. Khomeini, as the leading faqih,promoted the idea of maslaha or expediency arguing that for public good state can bypass sharia law. Zubaida 2005. Bulac argues that state should not bypass sharia law for public good. Bulac 2007, 91.
} 
to co-opt the ulema by patronizing Islamic law and acquiescing to other demands made by the masses of dedicated Muslims. ${ }^{77}$

The Sufi scholars preferred to stay away from direct involvement in the affairs of the state. Although they were also part of the ulema (Islamic scholars), they preferred to be independent from external constraints and political pressure; they therefore rejected government employment. Their rationale for remaining aloof from politics was to preserve the dignity of Ilm (Islamic sciences). ${ }^{78}$ Two major examples of the tension between the state and Islamic scholars with this type of mindset are of Imam Abu Yusuf and Imam Ahmad b Hanbal. Imam Abu Yusuf was one of the earliest Islamic scholars of the Hanafi school of thought; he accepted a government position and became a Qadi (Judge). ${ }^{79}$ Before him, other leading scholars (including his own teacher Abu Hanifa) had rejected similar offers to protect the integrity of their intellectual office. Imam Abu Yusuf's participation in politics led to his exclusion from the scholarly community. His critics argued that religious scholars should not be under the control of any government. ${ }^{80}$ Ahmad b. Hanbal was imprisoned by the state for not accepting a government mandated

\footnotetext{
${ }^{77}$ The exception is Shia Islam. Until the Qajar period the Shia ulema did not address the state because their position was made inviolate through their theology. Essentially, any claim to rule in the name of Islam was of questionable legitimacy in the absence of a recognized descendent of the Prophet Muhammad.

${ }^{78}$ Bulac states that Sufi scholars (Islamic scholars who did not accept government jobs) did not challenge the state directly; however, they continuously expressed their dissatisfaction in their theoretical writings concerning the ideal leadership and authority. This is what he calls quiescence (Temkin). Bulac 2007, 90.

${ }^{79}$ His real name is Yaqub ibn. Ibrahim al-Ansari, Esposito 2003, 5.

${ }^{80}$ For Imams rejecting government positions see Şener n.d and Bulac 2007, 88-94. Bulac argues that with Abu Yusuf's governmental job the decline of ulema began, as the state was able to successfully co-opt the religious leaders.
} 
theological position. ${ }^{81}$ He was severely punished and spent the rest of his life in jail and under severe conditions. Ahmad b. Hanbal's standpoint later became the mainstream for Sunni Islam. ${ }^{82}$

The ulema eventually gave in to the pressures of the political authorities but demanded that the state help establish the Shariah in return for legitimacy; after all, the name of the ruler was mentioned at every Friday congregational prayer. On the other hand, Sufi scholars had no interest in governmental affairs and preferred to live austere lives in personal devotion to God. As a famous example, tensions did lead to conflict with respect to controversial issues, some of doctrine and some of political power. AlHallaj was executed for saying ana'l haqq (I am the truth; or divine), but he also was aloof from the state and refused to use his popularity to give legitimacy to the Caliph. ${ }^{83}$

There was no authority that could monitor rulers in their handling of God's law. There developed a dichotomy wherein a certain body of scholars and their lay students and followers became tacitly aligned to the state, or ruling authorities, as the instrument to apply the Shariah in society as well as work for other Islamic causes. They did not intentionally sell their consent for the sake of establishing the Shariah. Nor did the Sufi scholars fall under the control of the government. The sufis were less inclined to associate with any institution because, more or less, their goal was directed towards

\footnotetext{
${ }^{81}$ The religious question was about whether the Quran was the created or eternal word of God. The Rival Mutazilite school of thought argued that the Quran was created because they wanted to safeguard the transcendence of God from co-eternality. Ahmad b. Hanbal rejected this view, arguing that Quran is eternal word of God and not created.

${ }^{82}$ Lapidus says that Hanbalis, Malikis, and Naqshbandis in India "not only maintained their autonomy, but were active opponents of state elites in the name of Islamic principles." See Lapidus 1994, 254.

${ }^{83}$ Lapidus 1994, 112.
} 
mystical experiences and worship. They did not have time for mundane issues, and often would use the materialistic hypocrisy of the ruling classes as pedagogical examples in their teachings.

This is a rough division between the ulema, who were involved in government, and Sufi mystics operating in society. Lapidus states that in the course of fifteenth and sixteenth centuries Ottomans brought the majority of the religious establishment under state control. The bureaucratization of the ulema gave them enormous access to positions and endowments, however, the ulema could no longer stay as the representatives of the Muslim masses. ${ }^{84}$ Ottoman ulema simply became civil servants paid by the state. ${ }^{85}$ Because the ulema grew close to the state and maintained rigid ideas about the law, they became deaf to social developments ${ }^{86}$. The classical texts (the Quran and Muhammad's recorded traditions) and scholarly debating circles is where the nature of Islam is defined. The state-backed jurists accepted the interpretations of the Hanafi school of thought which was introduced among the Turks by the various Naqshbandi orders. Overall, the Hanafi legal establishment allowed Sufi brotherhoods to practice interdependent and free in their own affairs. The autonomy accorded to Sufi brotherhoods was also useful to the Ottoman state which needed the cultural assets of these brotherhoods and their ability to organize and inspire people as the empire was expanding throughout the Balkans.

\footnotetext{
${ }^{84}$ Lapidus 1994, 326-27.

${ }^{85}$ Barkey 2008, 104-108.

${ }^{86}$ The Turkish Sheikh al Islam Zembilli Ali Efendi said "the gates of ijtihad (renewing the religion) is closed" arguing that the religious accomplishments until then represented the utmost developed version of Islam where there is no need to question and attempt to change it. Tarik Zafer Tunaya criticizes this situation and argues that, as a result, the Ottomans gave in to dogmatism. See Tunaya 2004, 48.
} 
Muslim immigrants voluntarily settled in the new lands and continued the proselytizing activities of their ancestors. $^{87}$

Originally, because Turkey was a religious country where the state was connected to the religious classes, ${ }^{88}$ this diffused religion and religious actors within all areas of the government. The scholarly religious classes (Ilmiye Sinifi) had the authority to judge religious issues. The highest religious authority was the office of Shaikh al Islam (Şeyhülislam). The decisions of the Ottoman Sultan became law after the, albeit symbolic at times, approval of the Shaikh al Islam. This system functioned efficiently during the age of Ottoman hegemony. Then the ulema fell behind in the production and dissemination of knowledge and other developments. As an institution, they were stuck in the past whereas all around them new modes and innovations were developing. Often the members of religious circles were themselves opposed to reform. They became the representatives of the status quo, which they identified with their own well-being. One major example is the opposition of the religious circles to the use of the mass print technology in Istanbul. They worried that if religious books were printed by machines hundreds of scribes would lose employment. ${ }^{89}$ This kind of opposition delayed the use of the printing press in the Ottoman Empire for over a century.

\footnotetext{
${ }^{87}$ The Bektashi orders carried on in this mission, see Lapidus 1994, 326.

${ }^{88}$ During the establishment of the Ottoman state, the Sheikh of the local business fraternity (Ahi) who happened to be the religious leader at the time presented Osman with a sword and gave him his daughter, Malhun Hatun. How symbolically and insignificant it might appear, at the time this was representative of a legitimation process for the political power in the eye of religious authority. For more see Koprulu 1992, 6; Inalcik 1973, 55

${ }^{89}$ Muteferrika was the first person to establish a print house in the Ottoman Empire. However it was closed after a bloody rebellion, supported by scribes, in 1730. Babinger 2004, 9 and 30-32. Bulac argues that after ulema lost their support from military circles because of the reforms of Mahmut II, they began to use shariah as a political tool in order to defend their weakening position against the newly rising pro-western
} 
The anti-reform status of the religious establishment and their inability to lead the country through changing historical circumstances came hand in hand with another development. As Serif Mardin reminds us, the decline of the religious classes (as a result of their inability to guide the development of the nation) came together with the rise of secular ideas from the European world. The bureaucratic elite (kalemiye sinifi which means "Men or Class of the Pen"), who had been closely allied with the scholarly classes, began to adopt the secular ideas of Europe where they went for education. They did not have a formal education in the religious sciences, as Mardin states, and they were more attracted to secular ideologies. ${ }^{90}$

As the new elite gradually preferred secular ideas to the previously dominant religious ones, they disconnected themselves from preceding Young Ottoman ideas and became the epitome of the secular ideas in the Ottoman bureaucracy. ${ }^{91}$ The decline of the status of the ulema and the rise of the secular bureaucratic elite corresponds to the reform projects of Sultan Mahmut II. He was the first Ottoman Sultan to introduce secular schools alongside the religious education system. ${ }^{92}$ Eventually they began to challenge the religious class, even on religious matters, based on the basic training they received in

secular elite. As a result, for the ulema anything coming from the west was considered as anti-Islamic and forbidden. Bulac 2007, 94.

${ }^{90}$ Mardin says that "Ottoman bureaucrats who were trained in the 'palace' system rather than in the madrasa (medrese), or religious school, had an unusual view of the interrelation of politics and religion. Their outlook may be described as raison d'etat." Mardin 1983, 139.

${ }^{91}$ Mardin argues that it is easier to show the transition from Young Ottomans to Young Turks and from Young Turks to Ataturk's revolution. However, he argues that the more important aspect of this transition is the gradual weakening of the Islamic content. See Mardin 1962, 404.

${ }^{92}$ Due to the overarching impact of his secular reforms Mahmut II (d. 1839) was called by the religious ulema as the "infidel Sultan" (Gavur Padisah). For more about Murat II's reforms see Heyd 1970. 
Europe. This, mainly French educated, generation of bureaucratic elite who acquired increasing power identified culturally and ideologically more with Paris than Istanbul. They wanted to displace the institutional power of the clergy in Istanbul in conscious emulation of the relegated clergy in Paris. ${ }^{93}$

Previously the bureaucracy served the interests of the nation with the same ideological commitment as the religious classes. However, the emergence of ideological differences between these two classes led the bureaucracy to begin to develop its own concept of religion as a private matter with no claim on the state or the political discourse. Winning the support of another class, the army officers (seyfiyye, the men of sword), like themselves who also did not receive a religious education, the bureaucratic elites moved to disentangle the office of the Shaikh al Islam from positions of influence with the Sultan. ${ }^{94}$ As the men of religion began to loose their authoritative status they

${ }^{93}$ Dar-ul-Funun (house of sciences), the first Turkish university in the modern sense was established in 1870 as a result of a proposal by a French politician, Jean Victor Duruy. Before he became the first educational adviser to the Turkish government, Duruy was the Minister of Education in France in 1863. As a result, Dar-ul Funun was founded under the auspieces of the French government. The director of Dar-ul Funun was a former madrasa teacher named Tahsin who was sent to Paris by the Turkish government in 1857. Berkes argues that "[d]uring the twelve years [Tahsin] spent [in Paris] he became a zealous disciple of modern science, a free-thinker, and a believer in progress. His new creed was the kind of materialism that raged in Europe after the publication in 1855 of Ludwig Büchner's Fraft und Stoff...the favourite of the Turkish doctors. Although a member of the Young Ottomans interested in the revival of the Muslim nations, Tahsin believed that the road to progress lay in the repudiation of religious dogmas and in enlightenment by science and education." For more see Berkes 1998, 179-181. On the other hand, Mardin informs us that the place of science and religion was debated by people under French influence and also by major Islamist figures. Jamaladdin Afghani was one of them. After his arrival to Istanbul in 1869 Afghani was invited to give a lecture in the opening ceremony of Dar-ul Funun. However, his ideas on science and religion created a controversy when they were interpreted as arguing for superiority of science over religion. Eventually other controversial debates led to the closure of the Dar-ul Funun University. For more see Mardin 2005 [1991], 12-13.

${ }^{94}$ For more see Tunaya 2003. Mardin explains this process as follows "for reasons which are not yet well understood, the Ottoman secular bureaucracy acquired increasing power during the eighteenth century..." He cites major examples where Ottoman Sultans executed influential religious leaders, or in 1703 a Seyhulislam who wanted the position of Grand Vizier. Mardin argues that "the most effective aspect of the Ottoman government's control over the 'Learned Institution' - that is, the hierarchy of men of religious 
started to express their increasing powerlessness in reactionary terms. The pan-Islamist policies of Abdülhamid II can be considered in this vein. For many Muslims in the country Abdülhamid II was the "Great King" (Ulu Hakan) who was considered "worthy of paradise" (Cennetmekan). It is during his thirty-three year reign that the Ottoman state faced the biggest political, economic and military challenges of its time. To protect the country from collapse, Abdülhamid II popularized the religiously based Shariah authority to a greater extent than many of his predecessors had done. ${ }^{95}$ He promoted Panislamism to keep the weakening empire together ${ }^{96} \mathrm{He}$ was harsh on opposition groups from the bureaucratic classes, which he repressed in order to forestall the decline of Islam as a result of the growth of a secularly inclined civil service and military. His reign represents the last attempt by a failing religious social institution to try to salvage a role for itself in a world order that it had previously ignored.

From the beginning, the religious orders (tariqahs) functioned as institutions for those who sought refuge from the spiritual emptiness. As they did for over a thousand years, the members of the tariqahs sought knowledge from learned, pious teachers trained in spiritual technique to maintain personal piety and purity. Over time, with the increasing influence of secular ideas into Turkey the religious orders and the political establishment became alienated from one another. However, not all Sufi scholars in the

learning or ilmiye- was that the more important ulema became in effect part of the official class and were dependent upon the state for their emoluments." Mardin 1983, 140.

${ }^{95}$ Hodgson says that 'Abdulhamid needed an ideology to enforce his despotism. "This he achieved through rallying conservative Muslim opinion generally, and particularly through encouraging a sentiment labeled 'pan-Islamism'. Hodgson 1974, 253.

${ }^{96}$ For more see Hanioglu 2001. 
tariqah networks prided themselves on these accomplishments because they were acutely aware of the rising secular threat to religion as a new phenomenon which required new techniques. For centuries, the Naqshbandi order had progressively been developing spiritual techniques for lay Muslims to cultivate a high level of faith. In these stagnant conditions, the older leaders of the Sufi tariqahs were unable successfully to address the threat of secularism and hegemonic western nation states: Britain, France, and Russia. Said Nursi would soon begin to argue that the institutionalized tariqah system (of the Naqshbandi) was not enough to meet the challenges coming from novel ideologies. ${ }^{97} \mathrm{He}$ argued that secularism was based in science and technology, thus they were more dangerous for a believing mind trained with the old methods. ${ }^{98}$ Rather than representing a competing religious belief system which could be dealt with by well trained scholars, secularism was empirical, objective, and empowering. The traditional tariqah system did not deal with the problems of the time. Therefore, Nursi did not join them and after abandoning his political career, he initiated a human-centric religious movement that focused on belief more than any other issue.

He proposed a renewed focus on Islamic tradition - for example, he denounced the primacy of the Murshid (the teacher in the religious orders) and argued that the only teacher is Muhammad himself - and the normative practice of Muhammad. ${ }^{99}$ For him this was the surest and shortest way to achieve a solid connection with God. From 1925 until he died in 1960 he published his ideas in a series of 114 books called the "booklets"

\footnotetext{
${ }^{97}$ Sixteenth letter in Nursi 1996, 375.

${ }^{98}$ Nursi 1996, 2205.

${ }^{99}$ Nursi 1996, 7-8.
} 
(risale). The booklets were his contribution to tafsir (interpretation) of the Quran according to the principles put forward by Muhammad. He rejected the institutions that had mixed the primary practice of the prophet with the teachings and methods of various teachers; he called his pacifist mission "Haqiqah."

Later, Necmeddin Erbakan's Islamist-National View Movement promoted an approach deeply attached to the self-other dichotomy and uses of the "other" in identity formation. Erbakan's movement has constantly been anti EU-USA, anti-Zionist and against the idea of religious dialogue. This is Shariah approach; ${ }^{100}$ it gives primacy to the authoritarian transformation of the society (similar to Abdülhamid II). The National View Movement is a relatively new movement with intellectual origins in the Naqshbandi tariqah. Some time in the late 1960s or early 1970s the Naqshbandi leader Mehmet Zahid Kotku directed Erbakan to establish a political party as a means of reaching out to the public.

Erbakan later used the nationalist anger of immigrant Turks in Europe to bolster his position as an Islamist leader. In doing so he applied the us-them dichotomy in identity formation in its most extreme form. With student organizations like National Youth Foundation (Milli Genclik Vakfi, NYF) National View Movement tried to establish Anatolian social bases. The ideological source of the movement is mostly a byproduct of political developments in the Middle East after WWII. The de-centralizing of the political right paved way for Erbakan to politicize the rising Muslim consciousness. The anti-western and antiIsraeli radicalization of the Islamic movements in the Middle East and the success of the Iranian revolution provided inspiration for him. From the beginning, Erbakan's movement

${ }^{100}$ By Shariah approach, I mean strict and narrow interpretation and implementation of law. 
sought out and utilized real and imaginary "others" such as Freemason, Zionists, Crusader Europeans, and the imperialist USA. ${ }^{101}$

The static Naqshbandi methods had long lost their appeal in the eyes of the masses, for which the Naqshbandi movement had little to offer in the face of enormous social and economic transformations. The Naqshbandi movement eventually became a rather closed community of like-minded members who no longer had an influence on the rest of society. Today most Naqshbandis dress and live more conservative lives than ordinary Muslims in Turkey. Besides personal conduct, Naqshbandi members often live in self-isolated enclosures (such as Carsamba in Istanbul). This is a result of an "other" consciousness; the Tariqah approach considers social life as the main source of moral degeneration and prefers to live in isolation from secular society, which it does not wish to engage. Their identity is not dependent on the existence of the "other" but they do recognize and are affected by secularists.

Nur community is trying to renew the tradition that had disappeared with the marginalization of the Naqshbandi movement. Followers of the Nur movement have a selfunderstanding that does not define the self in contrast to others because they are focused wholly on the practice of religion ${ }^{102}$ and work toward the ideal of Ihsan. In that sense the Nur movement can be considered as "otherless."103

An Islamic understanding of identity involves the normative construction of the self. However, these norms do not come exclusively from society but from revelation.

\footnotetext{
${ }^{101}$ Dagi 1998.

${ }^{102}$ Fifth letter in Nursi 1996, 355.

${ }^{103}$ Aras and Caha 2000.
} 
Revealed norms are to be experienced both individually and socially as a whole. The ethos of Islam originates in the Quran and the practice and teaching of Muhammad. The sources that Muslims read in order to understand the will of God for humanity are both universal and specific to the social conditions of seventh century Arabia. Traditionallythat is, before the rise of secular nationalism - Islam was practiced as a way of life and was relevant to every aspect of a believer's life. Actually, those who were sincere in their desire to know God and live according to the normative example of Muhammad were eager to model their lives on him. The Quran and Sunna were, and are, the foundation of the faith for the community and the individual. The raison d'être of Islam is to bring believers into the worship of God and to free them, or give them control, over their ego $\left(\right.$ nafs). ${ }^{104}$

This has always been in conflict with the anthropomocentricism dominant in a modern world. God consciousness is contrasted with the Ego in contrasting visions about the purpose of life. ${ }^{105}$. Living life without worshipping God is the definition of an egocentric life. ${ }^{106}$ Said Nursi argues that Islam tries to form a community that is made of responsible, God-fearing individuals. According to him, the person who is selfish will by definition put the satisfaction of personal desires before all else. To institutionalize and rationalize desire the ego must be able to define others from its own perspective. The ego,

\footnotetext{
${ }^{104}$ Bulliet explains how Islamic culture is transmitted by the prophet and his friends (as individuals) and transformed in later generations by individuals (by challenging the established authorities). See Bulliet 1994; Bulliet 1996.

${ }^{105}$ In Quran chapter 51 verse 56: "And I have only created the jinns and the mankind for nothing but they worship me."

106 The issues surrounding terrorist activities stem from a selfish identity formation that is more of a product of an egocentric or anthropocentric worldview then a theocentric, Islamic one. The literal reading of religion and its sources that cause radical activities is explained by Shah-Kazemi 2006.
} 
in Islamic and Sufi psychology, is not capable of understanding that it is a product of the external environment. The nafs is constructed in relation to an "other," and the nafs, like other structures or institutions, is interested in survival and power.

To be able to know and act upon the will of God, human beings need to have a well-developed identity. Human behavior is predicated on identity. The way people think about themselves will determine how they define the world around them and what paths they pursue. To have an identity one should be a Subject, the agent who acts upon an object. The object derives its meaning from the actions of a Subject upon it. The ego uses this dynamic to establish itself as a reality, as part of who we are. It does so by directing its gaze at an "other" and projecting ideas onto that object, this reinforces the ego identity. Ideally, the Muslim with faith uses the Quran and traditions to establish his or her identity. An "other" is not needed; in fact, identity formation vis-à-vis external objects would conflict with religious identity. ${ }^{107}$

The egocentric approach is applicable to the modern state. The modern state has two closely related characteristics that are relevant for this study. The first is that it is dependent on a materialist reading of the world and is only concerned about institutional survival and growth. In addition to this, it bases identity on a particular understanding of the material world: nationalism, communism, socialism. Secondly, it needs a real or imagined "other" in order to formulate identity. This dynamic is not only ideological but is the cause of real conflicts. According to Hobbes, the "other" members of society are mere enemies whom one naturally fears. People must strategize against various threats,

${ }^{107}$ In the Thirty third Word Nursi philosophically deals with this issue. Nursi 1996, 299. 
this is evident in his use of the famous saying Homo Homini Lupus. ${ }^{108}$ The social world is a brutish environment devoid of trust and security. The theory of state comes from this understanding, later explained by Weber, that to end all violence we need to give the state the monopoly of violence.

For Nursi, this understanding of social interaction should not have any place in Islamic theology. The triumph of Hobbesian realism represents a shift from the theocentric perspective to an egocentric mode. Said Nursi explains this situation as a loss of belief and trust in God. The consequence is that one's own self and the world begin to look like a Hell. Men by nature, according to Said Nursi, are limited to their own environment and do not have the ability to control the world around them; this gives rise to despair and a fixation on power and control. ${ }^{109}$ According to Nursi, the ability to construct a self-identity without comparing the self with external actors is only possible for the believer in God. Nursi argues that the self fails to truly understand its place, position and power because it has denied the relevance of God to life. There is separation between the self and God in Islam. In all three spheres - shariah, tariqh, and haqiqahthe self is subservient to God.

Nursi's point is in line with the Quranic story of Adam and his sons. ${ }^{110}$ The Quranic description of Cain and Abel identifies one of the sons as respectful to God,

\footnotetext{
${ }^{108}$ Man is a wolf to a man.

${ }^{109}$ Nursi 1996, 1961.

110 Chapter 5 verse 27: "And (O Muhammad) recite to them the story of the two sons of Adam (Abel and Cain) in truth; when each offered a sacrifice (to Allah), it was accepted from the one but not from the other. The latter said to the former: "I will surely kill you." The former said: "Verily, Allah accepts only from those who are al Muttaqun (the pious)."
} 
while the other was under the influence of the ego. Satan tried to create enmity between the two by showing the differences between them. When Cain mentioned the differences to Abel, his response was "I will not attack you I fear from Allah" Eventually Abel was murdered by Cain because of his need to identify the self in relation, negatively, with external objects. ${ }^{111}$ The Quranic message for Said Nursi is that the believer rejects the method of identity formation of Cain, who in an attempt to define his own identity through an imaginative misinterpretation of Abel committed a grievous sin. Nursi likes to focus on commonalities so that he trains his own ego in the opposite method. In his construction of identity the inclusion of other is dominant. He argues that against all the minor differences we have major commonalities: "we believe in the same creator, we believe in the same message, we believe in the same books, we believe in the same messengers." ${ }^{112}$ This is why he promotes inter-faith dialogue with people of the book, positive relations with Armenians, and decreasing the conflict between Turks and Kurds in contemporary Turkey.

Returning to the typology used in this work, what is particularly important about the Hadith of Gabriel is that the different modes of practicing Islam correspond to different tendencies in viewing others. As stated before, for the Shariah-based actors, such as Necmettin Erbakan and his political party movement, negative portrayals of the other is critical in constructing Islamic identity. It decreases in importance in the Tariqah approach and more or less disappears in Haqiqah approach. As different modes of

\footnotetext{
${ }^{111}$ The same story is more symbolically articulated by Naguib Mahfuz in his Children of the Alley, Mahfuz 1996, 75-77.

${ }^{112}$ Risale of Brotherhood (Uhuvvet Risalesi) in Nursi 1996.
} 
practicing Islam leads to different perspectives on others, this process has undeniable implications for the political process. The following chapters will analyze the historical trajectories of the three Islamic approaches and their relationships with the Justice and Development Party's policies. 


\section{Chapter III: NAQSHBANDI ORDER: TARIQAH}

In this chapter, I argue that the Naqshbandi tariqah is symbolized in the hadith of Gabriel by iman, faith. Its historical manifestation is characterized by the centennial renewal of the faith side by side the intellectual and theological critique of innovation. This approach is primarily practiced in inter-community relations (mostly closed to outside world) and a shared piety towards God. However, Naqshbadis had to deal with the fact of innovation and they became sensitive to the idea of "other" in terms of practices that deviated from the Islamic norms established by the Prophet and practiced by his companions. They look back to the earliest generations of companions as models of Islamic behavior. Because they were focused exclusively on the correct practice and belief they did not engage in controversial political debates. They substituted direct political involvement by indirectly working to influence the state from the grass-roots level. Their ideal institution was not the state, but master-disciple relationship, represented by the tariqah orders. The Naqshbandis attempted to influence the state through the individual leaders (caliphs) who lived in the capitol-major cities of the Islamic world. But they preferred to live secluded from the main centers of power.

Contrary to the literature of negative essentialists, the Republican Era was not an abrupt rupture of Islam's venture in Turkey. It was, rather, a period of change in what should be considered the continuity of Turkish Islam, one that outlived many of its political opponents. The Naqshbandi movement was very influential among loosely connected Muslims through proselytizing activities both among the elite and the masses; to better understand the role of the Naqshbandi tariqah in the venture of Islam I will 
analyze its impact on the secularized political arena rather than the impact of the secular state on Islam.

The most prominent tariqah among Turks has undeniably been the Naqshbandi tariqah. The Naqshbandi order was named after its founder Bahaeddin Nakqshband (b. $1318 \mathrm{CE})$. Over the centuries, the order became one of the most significant movements throughout Central Asia, Asia Minor and the Balkans. Eventually, Naqshbandi teachers socialized the majority of Turks into the practice of Islam. Its founder Bahaeddin promoted the spiritual development of individuals in the religious community through the implementation of the tradition of the Prophet Muhammad and other methods that Sufi masters had themselves innovated as a result of studying and practicing Islam.

In Arabic, tariqah means "the path, way." In the Islamic tradition, tariqah specifically involves the members of Sufi brotherhoods who follow specific paths developed in order to achieve understanding of divine reality (Haqiqah). This usually happens by passing through spiritual levels Maqam. Gilles Veinstein argues that initially this type of spiritual journey was a personal experience. After the development of the Sufi Brotherhoods, the accumulated experiences of generations of teacher and students were used to form a spiritual method and a corpus of rituals. In the tariqah, the leader who was addressed as Sheikh, murshid or pir educated his disciples (Murid) in specifically defined (or mechanical, to use Veinstein's words) ways to help murids along the Sufi path. ${ }^{113}$ The established oral educational system within the tariqahs involved teaching the very basic religious canon together with spiritual exercises meant to

${ }^{113}$ Veinstein 2004. 
discipline the self and ego. This required communities centered around the personality of the Sheikh. Sheikh-centered spiritual progress was mainly based on a negative understanding of societal influences that might deter the members from fully realizing the spiritual insights of the Sufi way. For them society was a dangerous place for the spiritual aspirant to be in because they were away from the Shaikh's guidance and subject to unknown cultural influences. Shaikh, who already passed many stages of spiritual development, knew what the student needed for spiritual development. Therefore, he wanted them free from the dangers of the society. ${ }^{114}$ This understanding inspired an Islamic life practiced mostly in intra-community relations secluded from the rest of the society.

The place of Naqshbandi tariqah is not only important in the societal realm. Its political involvement deserves equal attention. It would not be exaggerating to argue that all of the different Islamic movements that have had political aspirations since the $19^{\text {th }}$ century have been the members of a Naqshbandi order or one of its offshoots. Erbakan, founder of the Islamic political movement of National View, as well as the founding fathers of Justice and Development Party are notable ones. There are presently debates about the nature of the Islamic identity of the current Justice and Development Party government; to answer that question it is vital to understand the role of the Naqshbandi tariqah in influencing the Justice and Development Party. ${ }^{115}$

\footnotetext{
${ }^{114}$ Specific Naqshbandi term is "seclusion in the midst of society" (khalvat dar anjuman). For more see Kadri 1994.

115 According to Yavuz "[t]he Nakşibendi orders operate as a repository of virtually all cultural and religious traditions that have existed in Turkey; they bridge the gap between the Ottoman period and the current Islamic sociopolitical revival." See Yavuz 2003, 134.
} 
Mardin states that the "official history in Turkey only represents [the Naqshbandi tariqah] through events or rebellions where Naqshbandism is associated with fanaticism, treachery and reactionary qualities." This narrative, as Mardin argues, dismisses the positive contributions to society and culture during the period of growth of Naqshbandism. It gave birth to all of the most important Islamic social or political movements in modern Turkish history. ${ }^{116}$

The beginning of major contacts between the Naqshbandis and the administrating class dates back to the beginning of Islamization of Anatolia. Emergence of Islam in Anatolia was a direct result of the westward movement of missionary Muslim Turkish tribes from Central Asia. ${ }^{117}$ As they moved into Byzantine lands, the members of the Naqshbandi Order introduced Islam to Christians and pagans living in Anatolia. The institutions the order established were in the interest of proselytizing these people. When the worrior (Ghaza) state and its leader, Ghazi, made raids into non-Muslim lands the Naqshbandis used the opportunity to preach to the non-Muslim residents of the newly conquered lands. Similar to modern day missionaries Naqshbandis opened hospitals, soup kitchens and other social facilities where they served Allah charitable works. In his famous article, Barkan called them Colonizing Turkish Dervishes (Kolonizator Turk Dervisleri). ${ }^{118}$

Colonizing Turkish Dervishes were instrumental in the establishment of the consequent Seljuk and Ottoman states. The state became guardian of their religious

\footnotetext{
${ }^{116} \operatorname{Mardin} 2006,10$.

117 Özdalga 1999.

${ }^{118}$ Barkan 1942, 279-304.
} 
movement, and they were dedicated to protecting it against external threats. The idea of the state among these Naqshbandi orders has not been seen as merely "instrumental." They knew that they needed the state, however they were not necessarily happy with the unquestioned political authority of its leaders. They needed the leaders to provide services like security and safety so that the religious communities could flourish in society. Sometimes order members worked in administrative posts while some administrators became actively involved in the orders. Religious communities were constantly in contact with the state apparatus but this relationship was limited to appealing to the state to help religious orders spread Islam among the non-muslims. As a result, the Turkish state influenced society through its patronage of religious orders. This was a special kind of collaboration between the dervishes and the politicians, operating in their realm yet remaining separate. ${ }^{119}$

The focus of the Naqshbandi message comes from its call for renewing the faith through an emphasis on the practice of the early Muslim community. They view themselves as the legitimate representatives of the prophetic tradition, linked with Muhammad through a line of descendents going back to Abu Bakr. Abu Bakr is important for the identity of the Naqshbandi order because he was with the prophet from the beginning of his mission. The founding fathers of the Naqshbandi Tariqah view Muhammad as more than a historical figure. He is one sent by the divine will, and all his actions are worthy to be emulated. It was important for the Naqshbandis to trace their

${ }^{119}$ Serif Mardin calls this a special relationship in Mardin 2006. 
order to one of the companions of Muhammad because that was for them a source of legitimacy.

The Naqshbandis represent the tradition of renewal in religion, called Tajdid. The concept of renewing the religion, as Friedman states "stemmed from the conviction that the period of the Prophet was the ideal which should be recaptured." 120 This understanding is an implicit acceptance that as time passes the authentic practice of the religion decays and changes. Muhammad stated this in a hadith. 'The best of my community is the generation in which I was sent, then those who follow them, then those who follow them.' Friedmann argues that this "is only one of the numerous traditions idealizing the earliest period of Islamic history and indicating that a process of deterioration would set in after its completion."121 To remedy the deterioration Muhammad said that at the beginning or end of each century God would send one of his servants to the Islamic community who will renew the religion. Hamid Algar argues that this hadith should be accepted as authentic. ${ }^{122}$

Over the centuries, Muslim communities have followed different renewers (mujaddids). For the Sunni tradition in Turkey, the list of the mujaddids has some common personalities such as Imam Shafi'i, Imam Ghazali, Shah-i Naqshband, Imam Rabbani (Ahmad Sirhindi) and finally Khalid-i Bagdadi. ${ }^{123}$ The Nakshbendi tariqah in

${ }^{120}$ Friedmann 2000.

${ }^{121}$ Friedmann 2000, 13.

${ }^{122}$ Algar 2001, 291.

${ }^{123}$ Kisakurek argues that after Khalid al-Baghdadi comes his own Sheikh as the last (or $33^{\text {rd }}$ as stated in the title of the book) Abdulhakim Arvasi. For more see Kisakurek 1996; Kisakurek 1984. For the Nur community although they agree on the most if not all of the thirty-two mujaddids, the last Mujaddid is Said Nursi. 
Turkistan has generally tried to promote the acceptance of Mujaddids from the Naqshbandi ranks.

The Naqshbandi tariqah has a strict adherence to tradition and the idea of a renewal without innovation because Islam has always been and is still sufficient to answer all major questions in life. For Naqshbandis this is due to the divine source of Islam. In this understanding, tradition is equated with the actual revelation of God, as if its human agency is also divine. This is a major point where mainstream Naqshbandis and other major Islamic groups differ. Many Naqshbandis preferred to stay away from actively engaging in politics for the purposes of "al-'amal bi'l 'azima" and kept themselves in line with the tradition while the others argued that new circumstances required engagement with state institutions.

The division between those who follow "al-'amal bi'l 'azima" (acting with strictness) and "al-'amal bi'l rukhsa" created two major features that made up the Naqshbandi identity. The first one has been strict adherence to Qur'an and the tradition of Muhammad. This is the fundamental characteristic of the movement: renewal in the present and possibly the future by calling people to the past. Dina Le Gall argues that this has been the major Naqshbandi principle regarding tradition (the Quran and Sunna), ${ }^{124}$ which was the simplest representation of "al- 'amal bi'l 'azima". However, in order to renew and refresh religious practice some Naqshbandis tried to influence the ruling class and bring the state apparatus closer to religion. ${ }^{125}$ They created a mode of relating to the

\footnotetext{
${ }^{124}$ Le Gall 2003, 92.

${ }^{125}$ For more see Nizami 1991, 163.
} 
state where the tariqah and the state apparatus were in close communication but still maintained their distinct identity.

Different personalities in the Naqshbandi tradition brought different methods and messages within the overall renewalist tradition. However, this divergence of methods should not be viewed as rigid constructs of how these religious orders operated. Some Muslims felt that promoting tradition was the ideal method for the Islamization of society. Others wanted to use the power and influence of the state to advance religious goals. Although not recognized in the literature, still others were able to combine these two approaches to varying degrees. The high point of religious revival that was able to combine the sacred and worldly methods in the Naqshbandi tariqah was manifested in the personality of Sheikh Ahmad al-Faruqi as-Sirhindi, more commonly known as Imam Rabbani.

Under the leadership of Imam Rabbani (d. 1626), ${ }^{126}$ the order spread throughout the Indian subcontinent and transformed the heartland of the Muslim world. He came to be known as the renewer of the Second Islamic Millenium (Mujaddid Alf Thani). ${ }^{127}$ Mardin states that, for Sirhindi "religion was not just an ontological position, a metaphysical theory and a critical guideline, but an organizational means to stop its infiltration by creedal formulations of Hinduism, a policy he felt was encouraged by the Moghul ruler Akbar [Shah]."128 Sirhindi's local impact later spread throughout the Islamic world through his influential work and writings such as the Letters, the famous

\footnotetext{
${ }^{126}$ Some sources give the year 1624 or even 1627.

${ }^{127}$ Esposito 2001, 79.

${ }^{128}$ Mardin 2006, 10.
} 
one (Mektubat in Turkish). ${ }^{129}$ Rabbani's contribution to Islam was not limited to a spiritual renewal but also temporal organization and protest against Akbar Shah as degenerating figure because of his eclectic religious views. He emphasized that rulers should be strict followers and proponents of shari'a. Akbar was extreme: he tried to establish a syncretistic religion by uniting Islam with other religions in India.

Sirhindi's reaction was quick and fundamental. Lapidus summarizes his attitude towards others:

While florid forms of Sufism flourished, the syntheses of Muslim and Hindu practices abounded, and the Mughal state pursued a policy of conciliation among Muslims and Hindus, Sheikh Ahmad Sirhindi, who claimed to be the mujaddid, the renewer of Islam in his century, waged an unrelenting struggle to persuade the Mughal authorities to adopt policies befitting an Islamic state. He called for the imposition of the poll tax on the Hindus and insisted on the obligation of Muslims to subordinate rather than to integrate non-Muslims into an Islamic society. He also opposed the insinuation into Islam of Sufi and Hindu practices such as veneration of saints, sacrifice of animals, and religious festivals. ${ }^{130}$

Before Sirhindi the Islamic world had experienced physical and spiritual shocks, an example being the Mongol invasions into the heartland of Islam. However since the invasion of Kazan in 1552 by the Russians the Muslim world was perpetually losing ground to the rising western powers. ${ }^{131}$ The revivalist Islam of Sirhindi became one of the most influential messages throughout the Islamic world.

Sirhindi's goal was to ground Islam in the sources of revelation free from "alien" ideas. The historical encounter between Islam and Hinduism was, for Sirhindi, the main reason for the degeneration of the pure Islam. Therefore, he tried to emphasize an Islam

\footnotetext{
${ }^{129}$ After Imam Rabbani, the movement began to be called as Mujaddidiyya (Muceddidiyye).

${ }^{130}$ Lapidus 1997, 455.

${ }^{131}$ Mardin 1991, 210.
} 
solely based on Quran (the revealed text) and the Sunna (the living tradition of the Prophet). This is a common feature of all revivalists in Islamic history. Sirhindi tried to cleanse Islam from un-Islamic practices and innovations. He explains that during his spiritual experiences he elevated and saw that "the highest levels of saints were the ones who recited the prayers of prophet Muhammad rather than other ordinary or 'man-made' ones." Sirhindi argued that the surest way rise in the practice of Islam is to strictly follow prophet Muhammad's Sunna. ${ }^{132}$

Sirhindi and his renewalist movement were some of the earliest Muslims to sense the existential threat posed by foreign involvement in the heartland of Islam. This grew out of the realization that non-Islamic elements were beginning to influence Islamic culture in a negative way. His emerging awareness of foreign domination led him to speak about identity using an "us-them" dichotomy. With the experience of Sirhindi, for many Naqshbandi movements political activity became a viable means to further the interests of the religion.

Naqshbandis who were coming to similar conclusions began to deal with the threat of secularism the same way Sirhindi did. However, in the Turkish case the Naqshbandis developed similar methods of Sirhindi, as much as a century before him. According to Algar, in the late $15^{\text {th }}$ century Haji Ubeydullah Ahrar (d.1490) sent Emir Ahmed Buhari (d. 1516) and Simavlı AbdullahI İlahi (d. 1491) to Istanbul, capital of the Ottoman caliphate. Ubeydullah Ahrar, as Schimmel points out, was one of the major Naqshbandi leaders whose students traveled East and West Turkistan into China where,

${ }^{132}$ For more see Nursi 1996. 
inspired by their master's ideas, they tried to influence the political body to establish religious norms. ${ }^{133}$ Hamid Algar states that the earliest presence of the Naqshbandi order in Istanbul "was a result of direct transmission from the Central Asian homeland of the order." ${ }^{134}$ Contrary to scholars who attribute a greater degree of Sirhindi's influence on the Naqshbandi tariqah, direct transmission of was from Central Asia a century before of Sirhindi. ${ }^{135}$

The most significant and influential representative of the Mujaddidi branch over the course of Turkish history was Khalid al-Baghdadi ${ }^{136}$ (1777-1826). Khalid alBaghdadi was of Kurdish origin. He was born in Norther Iraq's Qaradagh region near Suleymaniyah. He is from the Shafii school of thought. From early on he received traditional Shafi'i Islamic education ${ }^{137}$ in and around his hometown. ${ }^{138} \mathrm{He}$ was also well educated in Islamic Jurisprudence (Fiqh). Later he became famous among his peers for his studies in other fields including mathematics, logic etc. During his life, the Qadiri order was predominant in his native region, but he did not join their order. Instead, he traveled to India to study with a famous Naqshbandi master named Abdullah Dihlevi. ${ }^{139}$

\footnotetext{
${ }^{133}$ Schimmel 1973.

${ }^{134}$ Algar 1999, 1.

${ }^{135}$ As stated in Irfan Gunduz's work this issue is significant because the Naqshbandis in Turkey usually trace their origins back to Sirhindi's Mujaddidi Naqshbandi branch rather than the Central Asian ones. They consider Sirhindi more prestigious. For more see Gunduz 1984; Mardin 1991.

${ }^{136}$ Or Ziya' al-Din Khalid al-Shahrazuri. Shahrazur is the province of the town of Qaradagh (Karadag in Turkish) where al-Baghdadi was born. For more see Abu-Manneh 1982, 2. The "al-Baghdadi" attribution is famous among Turks. On the other hand, some other sources cite his year of death as 1824 or 1827.

${ }^{137}$ Abu-Manneh 1982, 2.

${ }^{138}$ Memis 2000, 30

${ }^{139}$ Memis 2000, 54
} 
Abu Manneh explains that this is out of a spiritual quest where Khalid al-Baghdadi could not satisfy himself in Mecca or around his hometown. ${ }^{140}$ After receiving an intensive education and training under ed-Dihlevi he was given an ijaza authorizing him to teach according to the Naqshbandi method. He became deputy (Khalifa) but his diploma gave him an exceptional position, khilifa tammah mutlaqa, a rank as Abu Manneh explains edDihlevi seems to have denied other deputies. ${ }^{141}$ The date was 1810. As soon as he returned home, he began his teaching activities.

A few scholars call our attention to the organizational skills of a Khalid alBaghdadi as a religious figure. ${ }^{142}$ Mardin argues that what makes Khalid al-Baghdadi important is the originality in his method. Contrary to his predecessors, he was able to see the interconnectedness of the Islamic world. He organized his followers into small missionary groups and then sent them to different parts of the Islamic world in order to promote the religion. He stated during his time in India that he wanted to work for the material benefit of Islam. He contributed to this dream through his organizational work. Through the efforts of his students the work of Khalid al-Baghdadi has had a lasting influence on religious activism in the region. ${ }^{143}$ Khalid al-Baghdadi was aware that the ruling elite were only interested in worldly success so he paid attention to statecraft in order to influence society. ${ }^{144}$ As a result, he gave equal emphasis to the organizational

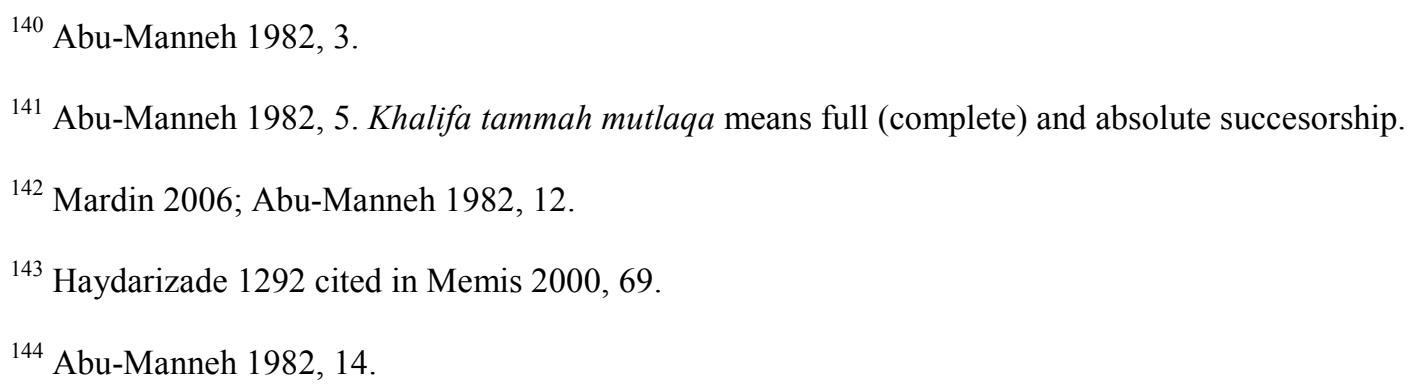


structure of the Naqshbandi order and the spiritual or religious teachings. In his writings to his deputies he mentioned in detail how to influence government officials. Sometimes Khalid al-Baghdadi argued that the reason the ummah went astray was because of its rulers. It was Khalid al-Baghdadi's vision that the Islamic world would be better off only by returning to righteous conduct. ${ }^{145}$ His principle focus in his both education and teaching was based on Fiqh (Islamic legal theory) rather than any other religious or positive sciences. This was a search for balance between worldly and religious pursuits. His superiority in the field of Fiqh is one of the reasons why he was able to attract such a large following, especially among other scholars from distinguished Islamic centers such as Bagdad, Damascus and Istanbul.

Khalid al-Baghdadi's network of deputies, with whom he was in constant contact, numbered no fewer than 116. This web of deputies transformed the region and made Naqshbandi dominant over the Qadiri order. There are other explanations for the success of the Naqshbandi order. Hakan Yavuz attributes the worldly success of Naqshbandis to the movements' 'democratization' of the deputy system. ${ }^{146} \mathrm{He}$ argues that in Qadiri tariqah the deputies or the masters were chosen from the family of the Prophet while in Naqshbandi eligibility was decided on the basis of ability and merit. Moreover, their liberal acceptance of new students increased their numbers so that they became the predominant tariqah in the region. Mardin argues that encounters of Naqshbandis with "Catholic and Protestant missionaries whose influence they had to combat" were instrumental in leading the Naqshbandies to develop better methods to promote the faith.

\footnotetext{
${ }^{145}$ Fore more see Abu-Manneh 1982, 14.

${ }^{146}$ Yavuz 2003.
} 
In Mardin's words, the Catholic and Protestant opposition and the sense of a powerful enemy "other" that it created made the Naqshbandis realize the need to increase their numbers and limit the appeal of rival ideologies. ${ }^{147}$ However, it is unclear just how influential these external influences were on the development of the method used by Khalid al-Baghdadi.

Because of his missionary system, Khalid al-Baghdadi was able to send his deputies to Muslim cities like Baghdad, Cairo, Jerusalem, and Asia Minor up to Istanbul. Memis lists 105 deputies of Khalid al-Baghdadi, 15 of whom were sent to Anatolia. ${ }^{148}$ The religious propagation of the this Naqshbandi branch throughout the Islamic world is important for the effects it had in Ottoman lands, Istanbul in particular. Mardin explains:

$\ldots[I] n$ the $19^{\text {th }}$ century the entire Anatolia began to be crisscrossed by Naqshbandi networks. The increasing penetration of Sufi orders in this area amounted to the implantation of elements of an Islamic civility at a time when the Ottoman Empire had been unable to intervene in the intertribal conflict and the ensuing anarchy. The Naqshbandi leaders also assumed roles of political leadership in this region. ${ }^{149}$

Khalid al-Baghdadi was careful in choosing his caliphs and providing them with guidelines when he sent them to important places. This demonstrates his ability to assess opportunities to promote Islam. It looks like he gave different guidelines for his representatives in accordance to the needs and ability of comprehension of the people in the places to which he sent them. The guidelines to his caliphs in Istanbul are especially

\footnotetext{
${ }^{147}$ Mardin 1991, 211.

${ }^{148}$ Memis also lists the representatives of these Khalifas along with a description of their duties and responsibilities. For more see Memis 2000 and especially chapter three.

${ }^{149} \operatorname{Mardin} 2006,11$.
} 
important. Es'ad Sahib explains the seven principles in detail. ${ }^{150}$ First, he did not want his representative going to Istanbul to establish personal friendship with government officials. Khalid al-Baghdadi was interested in influencing the political elite indirectly rather than via direct association. Secondly, Khalid al-Baghdadi did not want his representatives to pursue a salary or donations from the government. This principle was meant to sustain financial and religious independence from influence or manipulation by the state.

The third principle dealt with the personal family issues of Khalid al-Baghdadi's deputies. We know that Khalid al-Baghdadi and some of his disciples were polygamous. ${ }^{151}$ However, he prohibited polygamy for his deputies in Istanbul and argued that these kinds of marriages hinder the works of religious guidance (Irshad). The fourth principle was to preserve the dignity of the order by not intervening in the social relations of the visitors to or followers of the order. He also prohibited accepting money from the local people in exchange for religious counseling. Fifth, he regulated the relations of the deputies with women. Khalid al-Bagldadi did not want women, especially younger ones, to join the order. He thought that deputies associating with young women in the order would create problems. Sixth, he wanted the deputy in Istanbul to be in constant contact with him, even on minor issues. He instituted consultation on every issue and at regular intervals. The last principle is about living a humble life. He urged his followers to live a very modest life in imitation of Prophet Muhammad.

\footnotetext{
${ }^{150}$ Sahib 1334 cited in Memis 2000, 70.

${ }^{151}$ Memis 2000, 63.
} 
Most of these principles involve social responsibilities rather than personal ones. As a tariqah leader, Khalid al-Baghdadi emphasized the possible problems that would emerge in a cosmopolitan city like Istanbul alongside the spiritual problems the deputy might encounter. Because the caliph resided there, Khalid al-Baghdadi wanted to establish his tariqah in Istanbul on strong foundations and develop relations with the community. Khalid al-Baghdadi's vision was targeted on the Sultan and the bureaucracy and also Christian, Jewish and Shia minority communities. His letters demonstrate a negative attitude towards non-Muslims and non-Sunni Muslims. Abu-Manneh says:

"We find him exhorting his disciples to finish the "Khutm ul-Khaujakan" (i.e., the ending prayers which close the dhikr [prayer] in the Naqshbandi practice) by a prayer for God to "annihilate the Jews, Christians, fire worshippers (majus) and the Persian Shiites..."152

Because the Ottoman Sultans held the Caliphate, they were considered the representative of the entire Islamic world. Therefore, Khalid al-Baghdadi's antagonism against the Jews and Christians could be due to the Ottoman wars with the invading nonMuslim armies. Ottomans were losing on many fronts at the time and it probably increased the negative feelings among the Islamic communities toward the invading powers and their religions. Any war between Ottomans and any non-Muslim country was seen a war between Islam and its enemies. As Abu-Manneh says, in a letter to his followers in Diyarbekir in southeast Anatolia, he ordered his followers to pray for "the survival of the 'glorious Ottoman state' upon which Islam depends and for its victory

${ }^{152}$ Abu-Manneh 1982, 15. 
over the enemies of religion, the cursed Christians and the despicable Persians." ${ }^{153}$ Since the days of previous Naqshbandi leaders, Naqshbandi communities began to feel pressure from foreign opponents. Therefore, the Naqshbandis revivalists were defending traditional Islam against all kinds of cultural, social and religious degeneration. They were not tolerant of non-Muslim and non-Sunni elements in the Islamic world.

After Khalid al-Baghdadi died, the movement continued to be active in and around Istanbul. By sending more deputies and students to the region, the Naqshbandi movement was effectively identifying Istanbul as the center of gravity of the Ottoman and Islamic world. For its part Istanbul was the most stable region of the empire and ready for a spiritual and social movement. ${ }^{154}$ The best method for instituting change within the continuity of society was to slowly Islamize society through a return to Quranic and sunnatic principles. Another factor contributed in making the Naqshbandis influential in the capital. The military (Janissaries) backed by its religious wing had been holding an anti-reform position. The Janissaries who opposed to the military reforms assassinated Ottoman Sultan Selim III (1761-1808) who was known for his modernization efforts especially in the military. ${ }^{155}$

After Selim III, Sultan Mahmud II (1785-1839) got to the throne and began to implement reforms inside and outside of the military by supporting the Naqshbandis in

\footnotetext{
${ }^{153}$ Abu-Manneh 1982, 15. Lapidus's account of the events at the time might explain the situation. He says that "the dominance of Shi'ism was also assured by the violent suppression of Sunnism. ...Isma'il desecrated Naqshbandi tombs..." Lapidus 1994, 297.

${ }^{154}$ In his work, Algar explains how a Naqshbandi Sheikh fell in love with Istanbul and never left it. For more see Algar 1999.

${ }^{155}$ Selim III is famous for establishing the Nizam-i Cedid (New Order) army as an alternative to the antireformist Janissary Army. For more see Zürcher 2003, 23-26. For reforms during the same era see Berkes $1998,72-81$.
} 
order to fight against the Bektashi order, which was literally the religious wing of the army. However, Janissaries revolted against him when Mahmud II wanted to form another army. After a bloody attack, Sultan Mahmud II closed down the Janissary Army, in $1826^{156}$, and initiated many reforms ${ }^{157}$ and banned the Bektashi order. Under these circumstances, Mahmud II tried to utilize the Naqshbandis as a pro-sultan alternative to the Bektashis. The Naqshbandi tariqah, together with the Ulama, were more open to reforms initiated by the Sultan than other tariqahs. This is the beginning of the rise of the Naqshbandis. ${ }^{158}$ The replacement of the Bektashi Sheikh, after that order was dismantled by the Sultan, with a Naqshbandi one in the main Bektashi center ${ }^{159}$ shows that Sultan Mahmud felt it necessary to empower a more loyal one religious movement. ${ }^{160}$

Religious orders played a major role in articulating an authoritative interpretation of Islam. Mardin argues that when the Janissary corps referred to Islamic teachings they meant specifically their Bektashi interpretation of it. ${ }^{161}$ It was the only legitimate religious interpretation in the eye of many military staff. As Mardin states, the firman (religious or administrative statement) which abolished the Janissary Army and Bektashi

\footnotetext{
${ }^{156}$ Zürcher 2003, 39.

${ }^{157}$ Shaw and Shaw 1977, 36-50.

${ }^{158}$ Abu-Manneh 1982, 25.

${ }^{160}$ Abu-Manneh 1982, 28.

${ }^{161}$ Mardin 1956, 10.
}

159 This Bektashi center in Turkey is in the city of Kirsehir. The village where the founder Haji Bektash-i Veli's mausoleum is, has been recently named Hacibektas. In his work Faroqhi explains government efforts to justify confiscating the Bektashi lands and foundations and giving to the Naqshbandi order. All of these justifications however were on the religious grounds. See Faroqhi 1976. 
order, used religious justifications against these two institutions, arguing that Bektashi interpretation of religion was unislamic. ${ }^{162}$ The rise of Naqshbandis continued thereafter.

In the coming years, important personalities began to emerge within the Mujaddidi Naqshbandi tariqah. One of the most important representatives of them was Ahmed Ziyauddin Gümüşhanevi (1813-1893). Gümüşhanevi was from merchant family of the city of Gümüşhane from Northern Anatolia. At an early age he went to Istanbul to pursue a religious education. From 1831 to 1844 , he undertook traditional madrasah education and shortly after completing his education, he became a disciple of Ahmed b. Süleyman el-Ervâdî, one of the deputies of Khalid al-Baghdadi in Istanbul. Gümüşhanevi was initiated into the tariqah via el-Ervardi and his friends. Later Gümüşhanevi established his own tariqah (the Gümüşhanevi branch of Naqshbandi/Khalid alBaghdadi) in historic Istanbul by purchasing an unused or closed mosque and turning it into a new gathering place for his followers. ${ }^{163}$

Gümüşhanevi's rise in the community corresponded to the years of Ottoman decline. Two developments were particularly important. The first development was the 1878 Russian-Ottoman War. Gümüşhanevi rallied his students to volunteer in the war to

\footnotetext{
${ }^{162}$ The abolishment of the Janisary Army has become a major point in the westernization experience of the Turkish state and the society. Because Naqshbandis prefered not to interfere in governmental affairs Sultan chose them over other orders (especially the Bektasi order). Naqshbandis were happy with their favoured position. However, because of following reforms by the Sultan, government's control over Islamic foundations and institutions increased and the ulema and religious orders lost power in the military and many bureaucratic institutions. For more see Hanioglu 2008, 59. Importance of the Naqshbandi case lies in their ability to survive during both the Ottoman and Republican era while other orders lost their appeal.

${ }^{163}$ For more about Gümüşhanevi’s life see Gunduz 1984, 14-34.
} 
protect the Muslims and the Ottoman state. ${ }^{164}$ The second development was the emergence of a new kind of bureaucracy that trying to modernize the administrative system. Modernization of the empire hit the religious education system whose members were excluded from entering government posts. ${ }^{165}$ Only graduates of the secular military or regular schools were offered jobs in the government. Among other madrasah students, the disciples of Gümüşhanevi who did not hesitate to sacrifice their lives in the war to protect the state were excluded from government jobs by the bureaucracy of the very state that they fought for. Since then, this has become a dilemma that Muslims had to challenge. The very state that they fought for often times did not appreciate their sacrifices.

The madrasa accordingly lost its appeal and competitive edge. Gümüşhanevi’s major contribution was to revive the madrasah system by compiling major religious writings of the previous centuries that were not in the curriculum of religious schools. These attempts helped new students to access many authentic religious writings through Gümüşhanevi’s works. ${ }^{166}$ Gümüşhanevi knew that he was living in tough times and was aware of his limits. When the government decided to open an interest based bank he

\footnotetext{
${ }^{164}$ Borrowing from Algar, Yavuz mentions how the war united the Naqshbandis in defending the religion (din) and the state (devlet). For more see Yavuz 2003, 138. For Gumushanevi, religion and the state meant the same thing.

${ }^{165}$ Ortayli 2006.

166 The most prominent example is the inclusion of Jawshan in his compilation. Very popular in contemporary Turkey, Jawshan is a prayer that dates to the early part of Islamic history. The contents of this prayer were initially transmitted by the descendants of Muhammad. Said Nursi argues that the Shia origin of Jawshan is the reason it did not get popular among Sunni scholars. With Gümüşhanevi's compilation, it entered into the Sunni world of Turkish Muslims which later was used by Said Nursi. It is ironic to see Naqshbandis who were known for their anti-Shia stance to patronize Shia prayers among their followers.
} 
gathered all of his followers and established an assistance fund for his followers who needed money but did not want to participate in interest based banking. Gümüşhanevi was one of the earliest leaders to bring the community together and try to build institutions in line with Islamic principles. In the absence of an Islamic government, the Naqshbandis delivered services for society with weak leadership. ${ }^{167}$ Naqshbandis, instead of challenging the government, offered solutions to emerging problems through their own social networks. Via the community bank the members of the tariqah loaned money to other community members without charging interest.

Gümüşhanevi died in 1893. Among his major followers were Haci Hasib Efendi, Abdulaziz Bekkine and Muhammed Zahid Kotku. Haci Hasib Efendi (d. 1949) assumed the Naqshbandi post because he was older than the latter two. Haci Hasib Efendi was known for his soft personality which was not able to challenge to the modern life style imposed by the devastating wars and social trauma. Kotku and Bekkine who were much younger would be more influential in the Naqshbandi history. Both Kotku and Bekkine had some form of spiritual and religious training before they received Naqshbandi training. Originally, Kotku introduced his close friend Abdulaziz Bekkine to the order. They studied the Naqshbandi thought from the deputies of Gümüşhanevi. Naksibend message became more appealing to them than any other tariqah available in Istanbul area. Bekkine was older than Kotku. Therefore, the Naqshbandi establishment (including Kotku himself) chose Bekkine for the post after the death of Haci Hasib Efendi. Kotku left for Bursa, a historically important city, and continued his teachings there. Bekkine

${ }^{167}$ For more see Gunduz 1984. 
had a short but successful tenure. He became the imam and preacher of the Ümmü Gülsüm (Umm Kulthum) Mosque in the Fatih district of Istanbul which was the center of the Gümüşhanevi Naqshbandi order. During his short tenure, Bekkine transformed the order and made it open to greater parts of society.

Two different reasons can be given for Bekkine's success. One is due to the structural changes in Turkish society. He assumed Naqshbandi leadership at a time when Turkey was passing from autocratic single party rule into multi-party democracy. Repression of religious education was loosened and Muslim scholars had more opportunities to promote Islamic teachings and practice. ${ }^{168}$ However, his personality is more useful to explain the success of his institute than the structural considerations. Bekkine was young, energetic and, due to profound life experiences, visionary. His parents were originally Muslim subjects of Russia who immigrated to Istanbul before Bekkine was born. During his early childhood, he went back and forth between Kazan, Bukhara and Istanbul for his religious education and family businesses. During these trips, he was able to compare and contrast the positive and negative practices taking place in Muslim societies. In one of his speeches, he gave an atomistic explanation about the salvation of society from decay:

When I was returning to Istanbul from Russia, we took a Turkish ship. The Turkish conductor began to check for the tickets. When he found out that an old and poor man took the ship without purchasing a ticket he kicked him so bad that poor man fell on the floor. The Italian captain [unhappily] on seeing this, called the old man to his room and respectfully hosted him until we had arrived in Istanbul. ${ }^{169}$

\footnotetext{
${ }^{168}$ Jenkins 2008, 118-119.

${ }^{169}$ Catakli 2000, 40.
} 
The Italian captain was more in tune with the behavior that characterizes Muslims than the Muslim conductor. Therefore, what became clear from this story to Bekkine was that one's identity does not create or account for their personality. It is incumbent on individuals to construct their own personality, consciously, in relation to God.

As was the case for all Naqshbandis, teaching the Islamic message to all members of society was the principle motivation for Bekkine. Like his predecessors, Bekkine based his activities in the mosque. Upon listening to Bekkine speak, those who regul arly attended the mosque joined the movement and later rose in its ranks. At that time there were very few practicing Muslims so it was crucial for Bekkine to win over ordinary Muslims to the basic practice of Islam. The limited number of religious institutions in Istanbul provided an opportunity for nontraditional Islamic movements to emerge easily and compete for followers. For a traditional movement like Naqshbandism this was a major concern. Bekkine was persistent in trying to keep the congregation within the Naqshbandi tradition rather than joining other nontraditional movements. ${ }^{170}$ Bekkine passed away in 1952 and his close friend Kotku moved to Istanbul to replace him. The Naqshbandi community wanted Kotku as the new Hocaefendi, Senior Teacher, to replace Bekkine's official government post in the Ümmü Gülsüm Mosque. With the help of the Directorate of Religious Affairs (Diyanet Işleri Başkanlığı, Diyanet), the government office in charge of all mosques and religious institutions in the country, the Naqshbandi movement was able to install Kotku inBekkine's mosque as the new Imam.

\footnotetext{
${ }^{170}$ For more see Catakli 2000.
} 
For a short period, Kotku preached in the same mosque in the city of Fatih in Istanbul. Ummu Gülsüm mosque was relatively outside of conservative Fatih closer to Eminonu which has been a commercial center where both Muslims Turks and nonMuslim minority resided. In 1958, Kotku moved to the Iskenderpasa Mosque which was at the heart of Fatih's central residential neighbourhood. Iskenderpasa Mosque became the main center for the Naqshbandi movement. ${ }^{171}$ This shows that Kotku was able to transform the small mosque community at the suburbs of the town into a major one at the heart of Istanbul. Later Kotku's Naqshbandi branch was named after the mosque it is centered around; the Iskenderpasa community. In the new mosque, Kotku was able to institutionalize his community in many different areas.

During his tenure, Kotku encountered issues that none of the previous leadership experienced. First, as Turkey passed into the multi-party system, the Democratic Party (Demokrat Parti, DP) came to power in 1950 with the support of the dissatisfied Muslim periphery both in the cities and in the countryside. The DP was a secular party that had sympathy towards Muslims' cause and eventually it easened up the restrictions on the religious practice. There were more pro-Muslim members in the party who, together with

\footnotetext{
${ }^{171}$ When I was in Istanbul, I visited both mosques and met with members of Naqshbandi community. In one occasion, they told me two different stories why Kotku left Ummu Gulsum mosque and moved to Iskenderpasa. Some argued that, there was a road construction near the Mosque and Kotku was not comfortable in preaching in the construction zone, so he left for a more comfortable setting. More convincingly, others argued that due to the increasing number of followers, the smaller Ummu Gulsum mosque was not large enough for the bigger congregation and it was not close to the community who lived in the central town.
} 
their secular friends, were against the authoritarian policies of the Republican People's Party. ${ }^{172}$

After the multiparty era, the Republican People's Party was never able to get the majority vote in the elections. On the other side of the political spectrum, the DP and its successors capitalized on disaffected Muslim voters by addressing the religious concerns of the Muslim population. ${ }^{173}$ In this era, a new but relatively marginal generation of young Muslims emerged. They were mainly from the countryside where the secularization reforms enacted by previous governments were not able to take root as they did in the city centers. Back home these immigrant populations had the opportunity to learn and practice their religion in their homes or via underground religious organizations led by local religious orders. When these young Muslims moved to the major cities to pursue higher education they began to deal with the contradictions between their cultural roots and the requirements of modern life. Particularly important were students from the engineering departments of schools like Istanbul Technical University. They attended the university during the day and at night they were in the Iskenderpasa mosque or in the Imam's house listening to religious sermons (sohbet) to purify their hearts. ${ }^{174}$

\footnotetext{
${ }^{172}$ The DP is famous for reinstating the Arabic call for prayers (Ezan in Turkish and Azan in Arabic) in the mosques. Until then the preceding CHP forcefully imposed a ban on Arabic Ezan. For Turkish Muslims Arabic Ezan was a religious symbol, which should be practiced only in its original Arabic form.

${ }^{173}$ Other religious parties in Turkey were all shortlived. For more see Jenkins 2008.

${ }^{174}$ Naqshbandis believe that sohbet polishes (or paints) the heart. In Turkish "Sohbette insibag (sibgha) vardir." Sibgha in Arabic means paint.
} 
The most prominent products of this generation were Necmettin Erbakan, who established Turkey's first Islamic political party, and the Özal family which produced major politicians over the next forty years. Korkut and Yusuf Bozkurt Özal became ministers in different cabinets while Turgut Özal became prime minister two consequtive terms and the president. Korkut Özal began to meet with Muhammed Zahit Kotku and the Naqshbandi movement at a time when he was spiritually challenged. ${ }^{175}$ His story is representative of the lives of other students, workers, and professionals who tried to fill the void of a secular life style with religious practice. Kotku had a successful career as a civil engineer and government employee. His experience in the USA in the late 1950s for language and professional training was very interesting. It was the first time he became aware of the place of religion in public life. The uses of religious symbolism in public life or the first amendment right to practice religion made Korkut more conscious of his own religion. ${ }^{176}$

When Korkut Özal returned to Turkey, he consciously sought to lead a more religious life. He read many books on a variety of aspects of Islam and began to socialize with Muslims at the mosque. One individual who he met helped him to focus his spiritual energy in ways he could not have figured out on his own. Korkut became one of Mehmed

${ }^{175}$ Özal 1999, 159-176.

${ }^{176}$ This happened, although, at a time when famous Sayyid Qutb visited the USA where he became irritated by the life style in American society while Korkut Özal found ways that made him more religious. Qutb's American visit often times is represented as the source of his radical transformation and an important example of the inability of an Islamic identity to live side by side with a non-Islamic identity. In the similar case of Korkut Özal as a prominent Islamic figure in Turkey, however, the impact of meeting with the "other" is opposite. In his article Korkut explains how Americans were able to keep religious symbols in their lives, this ability influenced him positively. For more see Özal 1999. 
Zahid Kotku's pupils in 1960, and their friendship lasted over 20 years. ${ }^{177}$ His brother and many other professionals from Istanbul Technical University (ITU) and other government institutions followed the same path. Ersin Gurdogan, a graduate of ITU, calls this an Invisible University (Görünmeyen Üniversite) where students from prestigious secular government schools seek spiritual guidance and religious instruction from Islamic leaders. ${ }^{178}$ Weekly meetings, which lasted only a couple of hours, helped to develop group solidarity and personal relationships that later re-invented the Islamic movement and gave birth to grass-roots social-political institutions in the country.

Zahid Kotku was the most influential proponent of Islam in modern Turkish politics. Among his students were the charismatic leader, Necmettin Erbakan, who later became prime minister. Erbakan met Zahid Kotku while he was in college. Erbakan later became a successful professor and an active member of the political community. He subsequently became the general secretary of the Turkish Chamber of Commerce. However, he was later ousted from that position. In the 1960s, with the support of Naqshbandi community, Erbakan began to establish the foundations of a religious opposition movement that would challenge the secular elites in the government.

Kotku did support the political party of Erbakan, however, the nature of the relationship between his tariqah and Erbakan's political party is unclear. Existing studies portray a direct connection between the Naqshbandi tradition and the rise of the Islamic party. However, though they both pursue the interests of Islam, the relationship between the Naqshbandi leader (Kotku) and the leader of the political party (Erbakan) has been 177 Özal 1999.

${ }^{178}$ Gürdoğan's book on the 'invisible university' of Kotku is one of the rare sources. Gürdoğan 2008. 
rather ambiguous. ${ }^{179}$ When they began engagement in politics it appears that Kotku and Erbakan had different expectations. For Kotku the political process was only one method among many for the pursuit of Islamic interests. Erbakan viewed the state as the agent of religious reform, or at least an integral part of it. Kotku always warned his students against the inherent corruption of politics, where human self (nafs) is vulnerable to temptation; similar views were put forward by traditional scholars like Said Nursi. Kotku recognizing the importance of participation in electoral politics to serve religion, and was supportive activities of Erbakan, but he never directly engaged in political campaigns or recommend one party over another. Kotku viewed politics as a modern social club that could be used to reach out to the community. ${ }^{180}$

It appears that as a religious leader Kotku underestimated the power of politics vis-à-vis traditional means of social mobilization. Erbakan was a young and energetic leader who was able to achieve some political success and attract large sectors of the electorate who thought that controlling the political sphere would be a more viable way to servereligion. Shortly before Kotku's death he became annoyed with Erbakan's activities. In the late 1970s protests were occurring all over the country. Erbakan wanted to capitalize on the discontent of young Muslims but this opportunism was not welcomed by Kotku. Yasar argues that Kotku first asked Erbakan to close the youth organizations which were involved in the street protests. After a while Kotku took a more radical step and asked Erbakan to close the party entirely. He realized that the party and its regional

\footnotetext{
${ }^{179}$ I obtained this information in November 2006 in Istanbul from one of the weekly lectures given by the followers of Kotku in a student hostel where they tried to continue the sohbet (informal lecture) tradition of Kotku.

${ }^{180}$ Yasar 2004, 329.
} 
organizations had become part of the problem rather than offering an Islamic solution to social discontent. ${ }^{181}$

Kotku had a balanced approach to politics: he kept in contact with the Islamist party of Erbakan but consistently warned his followers against the dangers of directly engaging in politics. We can argue that his Islamic background detracted him from getting involved too much with politics. The political option was a novel approach because of the democratic context but Kotku feared from the negative impact of it in the polarization of the society. The society that he wanted to transform was not the same one that his predecessor Khalid al-Bagdadi dealth with. The newly rising generation of the ordinary Turks most of the times saw Kotku's method as unaaceptable. Kotku lacked the ability to form an institutional structure (schools, newspapers, civil society organizations) to reach out to his opponents and inform them about his message. The tariqah method simply lacked that ability.

Naqshbandi tariqah, therefore, returned to emphasize the social agency of the individual believer more than the party. This means that the social group must focus on influencing each individual through inter-personal communication, something the state could not do without being coercive. Kotku thought that Erbakan, because he came from the same social milieu in the Istanbul mosque network, would not initiate policies that contradicted the principles of the order. However he overestimated the strength of Erbakan's commitment to Naqshbandi principles.. Erbakan wanted to be an independent politician who did not want to be constrained by the 'limited' vision of the order.

${ }^{181}$ For more see Yasar 2004. 
Moreover, he was riding a wave of popular support that would eventually make him a Turkish Prime Minister. Eventually unrest in the streets led to the coup d'état of 1980. Kotku also passed away in the same year so there was no authoritative leader capable of challenging Erbakan.

The Turkish Naqshbandis were single-mindedly focused on bringing nominal Muslims into their mosque networks and teaching them the basics of Islamic doctrine and prayer. In this sense, they were unprepared to deal with intricate delicacies of the political process. Erbakan's emergence in the political arena and weakening of Naqshbandi support for him highlights the differences between shariah-based Islamic activism and Iman, or faith-based activity. Erbakan was a shariah-based actor motivated by the prospect of bringing his brand of Islam to influence state institutions. The Sufi orders, going back to Khalid al-Baghdadi, were interested in politics only to the extent that they themselves could propagate Islam directly to state officials. Erbakan was closer to Islamic movements throughout the rest of the Middle East who sought political success than to the traditional orders. He, therefore, tried to establish his own community through the party members that followed him.

Like Erbakan, Kotku's other students had engineering backgrounds. They did not receive formal religious education from Kotku, whose lectures were informal question and answer sessions without a developed curriculum. Kotku picked the topics himself for the benefit of the students. Few if any of them pursued religious training. ${ }^{182}$ Tension

\footnotetext{
${ }^{182}$ In November 2006, during my visits to Naqshbandi circles in the Fatih district of Istanbul, where Kotku lived, some from the earlier generation of Kotku's followers, a few of whom later became successful businessmen and politicians, told me that they were not satisfied with Kotku's style due to its unstructured nature. Because they were already in an active political or business life, they wanted more concrete gains which they couldn't get from Kotku. Most of them later preferred Erbakan to Kotku.
} 
increased after Kotku passed away. Before his death, Kotku informally appointed his sonin-law Muhammed Esad Cosan to his place by making him the formal lecturer in the weekly lecture series. Within the community, especially among those with secular degrees, Cosan was not welcomed. These professionals took a mechanical approach to Islam similar to the vision of Erbakan. Cosan was a soft-spoken, learned Islamic professor who was well versed in Arabic, Persian and Hadith tradition; but he did not possess political acumen. Nor was he a formal madrasah graduate with a traditional Islamic education like his predecessors. As a result, the political wing was able to discredit him. Cosan then became a small community leader position until his retirement while Erbakan's followers devoted their time excitedly to political activities. This division empowered the politically oriented shariah approach of Erbakan's and irrevocably limited the power and influence of the traditional tariqahs in Turkish politics.

Many Muslims associated with the Naqshbandis and Erbakan began to consider Erbakan's method more relevant to the political situation in the country. Only after his retirement from his teaching position, did Cosan become more active in community activities by publishing magazines and establishing a national radio station, which eventually became AK TV. However, Erbakan was at the height of his influence among Turkish Muslims. Even those who listened to Cosan's teachings considered him relevant only to spiritual and not political affairs. His TV and radio programs were later barred by the government in the wake of the 1997 military coup d'état, and he left Turkey to live in 
self-imposed exile in Australia. ${ }^{183}$ After his death in a tragic car accident, the unity within the tariqah movement was lost for good.

The major problem with the Naqshbandi movement of contemporary Turkey has been its inability to revive Islam with the kind of energy and effectiveness characteristic of Sirhindi, Khalid al-Baghdadi, and later Said Nursi. Ubeydullah Ahrar, Imam Rabbani, Khalid al-Baghdadi and to a lesser extent Gümüşhanevi and Kotku were effective within the contexts of their times and provided relevant religious motivation that increased the dedication of many of their lay followers. However, the process of urbanization and stateadministered modernization in contemporary Turkey made it impossible for the traditional methods to survive. The superiority of secular ideologies and institutions in the country created a number of significant obstacles for tariqahs. They were not able to mobilize people politically and their religious message became subsumed in the identity politics of Erbakan.

This chapter tried show that the strategies employed by the Naqshbandi movement to influence the state from the outside backfired during the republican era. Previously they were respected and sought out for guidance in religious matters. After the institutionalization of the secular state their political position became irreparably marginalized. Tariqah approach was unable to accommodate to the new social and political arrangement where the public sphere was cleansed from any religious representation by the Kemalist revolution. In such an alien setting, Tariqah approach did not effectively answer the dominant questions of modern life. As they wanted to adapt to

${ }^{183}$ See Bacik 2002. 
the new political system they tried to initiate a new political party controlled by the social movement. However, it appears that the leaders of Naqshbandi tariqah underestimated the power of political process and politicians, even the Naqshbandi influenced ones, who attribute autonomy of space to it. 


\section{Chapter IV: THE NATIONAL VIEW MOVEMENT: SHARIAH}

This chapter is about the Shariah approach as outlined in the Hadith of Gabriel as Islam. It is the most basic level because it only requires the acceptance and practice of the main tenet of Islam whereas iman and ihsan are an internalization of these fundamental principles. The Shariah approach is exclusively interested in occupying institutional positions of power. It interprets the problems of modernity as an absence of divine directive in society. While all of the major Islamists in Turkey agree on this point, the Shariah based actors, in this case Necmettin Erbakan, believe that the problems associated with modernity will be solved by merely institutionalizing Islamic Law.

Necmettin Erbakan's National View Movement was originally a political branch of Kotku's Naqshbandi movement. Erbakan began to establish political parties in the early 1970s under the auspices of the Naqshbandi tariqah. ${ }^{184}$ Later, the National View Movement distanced itself from the tariqah network and immersed itself in the political process. Erbakan disagreed with the Naqshbandi method of influencing the state through social activity and religious propagation and embraced political involvement. His earlier connection with the Naqshbandi tariqah caused observers to associate the National View Movement's Shariah approach with the Naqshbandi movement.

For the National View Movement, controlling the state via democratic elections has been the primary goal. Inspired by Islamic movements in the Middle East, Erbakan sought to implement religious law. ${ }^{185}$ The National View Movement tried to

\footnotetext{
${ }^{184}$ Özal 1994.

${ }^{185}$ Dagi 1998 explains the connection between the National View Movement and Islamic movements in the Middle East which created the anti-EU identity of National View Movement. Gareth Jenkins states that "In his public statements, Erbakan made no secret of his nostalgia for the Ottoman Empire, although he usually
} 
institutionalize Islam as a structural factor in the state's law-making and enforcing body. The ideas of Sayyid Qutb were the intellectual foundations upon which the National View Movement based its design for an Islamic revolution. The Soviet invasion of Afghanistan and the success of the Iranian revolution eventually led to the popularization of Islamic causes and the Shariah approach. By capitalizing on the sufferings of Muslims abroad, the National View Movement was able to channel the dissident and discontent voices to the political arena in which they were the primary representatives of Turkish Islamic identity. As a product of $20^{\text {th }}$ century democratic politics, the National View Movement has managed to become a popular Islamic movement, however, overall solidarity of the movement is only a few decades old.

In a secular state such as Turkey, where the military has sponsored coups in defense of the secular establishment, Erbakan's prominence among both political and religious circles merits the attention of serious scholars of Islam and democracy. He was the first politician to bring the message of Islam to the parliament. Other Muslim politicians preferred to blend their ideas with conservative ${ }^{186}$ and centrist ideas, but Erbakan was explicit that the political platform of his party was "Islamic". In contrast to other traditional religious leaders, Erbakan did not receive formal religious training. ${ }^{187}$ Erbakan was born in a more or less secular environment. His father was a judge in his

stopped short of explicitly calling for the restoration of the Shari'a." Jenkins, 2008, 131. Emphasis in the original.

\footnotetext{
${ }^{186}$ In Turkish context, conservative "muhafazakar" means "respecting religion" and resisting abrupt changes.

${ }^{187}$ Interestingly enough, in Turkey non-Islamic fields like engineering or science are producing Islamist political actors rather than traditional Islamic institutions.
} 
hometown of Sinop. Sinop was a secular city in a relatively conservative region. Throughout his early life, he received a good secular education and was quite successful in it. His family later moved to Kayseri and then to Istanbul where Erbakan attended the prestigious Istanbul Erkek Lisesi (Istanbul Boys High School). Later, he attended the Istanbul Technical University (ITU) ${ }^{188}$. Among his classmates were Korkut Özal (former minister), Suleyman Demirel (former Prime minister and $10^{\text {th }}$ president) and Turgut Özal (former Prime minister and $9^{\text {th }}$ President). He became involved with the Naqshbandi order while he was in college.

One campus of Istanbul Technical University was located in the district of Besiktas which was very close to the center of Naqshbandi activism in the neighboring district of Fatih. Fatih was named after Mehmed II (Muhammad the Conqueror) who conquered Constantinople in 1453; after the conquest, he was nicknamed "Fatih," meaning conqueror. The famous mosque, the Fatih Mosque, on the historic peninsula of Istanbul is also named after him. ${ }^{189}$ Today the Fatih Mosque is not only famous for prayer services but also for its funeral ceremonies. Out of a symbolic gesture, funeral services of famous Muslims are usually done in the Fatih Mosque. This has been the case for especially for the Naqshbandis.

Some famous Muslim figures whose funeral services were done in Fatih Mosque are Naqshbandi Sheikh Esad Cosan, famous Muslim poet of Naqshbandi origin Necip Fazil Kisakurek, former prime minister and President Turgut Özal (whom we later

\footnotetext{
${ }^{188}$ At the time, ITU as the leading engineering university in secular Turkey was becoming a hub for the religious Naqshbandi movement.

${ }^{189}$ The difference of Fatih from rest of the city and its European quarters (i.e. Harbiye) were also portrayed in Peyami Safa's famous Fatih-Harbiye novel. For more see Safa 1995.
} 
learned that was also linked to Necip Fazıl and Naqshbandi Sheikh Zahit Kotku). ${ }^{190}$ After the building of the mosque, the city became known as Fatih. Most of the conservative students who attended Istanbul Technical University during 1960s and 1970s used to live in Fatih. They were easily able to commute to college in the neighboring town while living close to their Sheikh in Fatih. During his college years, Erbakan practiced Islam and associated with the students and Sheikhs. ${ }^{191}$ In 1953, he became associate professor and was also active in business life. In 1956, together with friends from the Naqshbandi community, Erbakan established the legendary 'Gümüş Motor' company in Konya. ${ }^{192}$ Gümüş Motor was the single most important business venture by Erbakan and his associates. Although Gümüş Motor eventually failed, Erbakan's followers used it as a model of indigenous industrialization.

After the failure of Gümüş Motor, Erbakan entered the Turkish Chamber of Commerce (Türkiye Odalar ve Borsalar Birliği, TOBB) in 1965. He later became its general secretary. He was trying to be the voice of small business owners on the periphery against the big corporate elite centered in Istanbul. In an attempt to widen his sphere of influence, he ran for the presidency of the Chamber which was the biggest trade chamber in the country. In May 25, 1969, he won the presidency of the Chamber at the expense of the corporate elite. Süleyman Demirel, who was both the leader of the ruling

\footnotetext{
${ }^{190}$ In my research trip to Turkey in late 2006, some Muslim residents of Fatih told me that it is now a common understanding among the residents of Fatih that, to have a funeral ceremony in Fatih Mosque is an expression of Muslim identity. For many Muslims, this is probably another way of developing a language in a secular country to convey a religious message.

${ }^{191}$ He graduated in 1948.

${ }^{192}$ A company that manufactured car engines.
} 
Justice Party (Adalet Partisi, AP) and the Prime Minister opposed Erbakan's election arguing that Erbakan as the General Secretary of the Chamber could not run for president. The case was taken to the court where the court decided in favor of Demirel. In August 8, Erbakan lost his position but did not want to leave. Erbakan locked himself into the president's office leaving the office only after police broke the door in.

Consequently, what brought Erbakan to the forefront of the political arena was his rivalry with Suleyman Demirel. Often Erbakan's "us against them" discourse found its utmost representation in Demirel's personality. As a result, with the support of his closest friends from Demirel's party, Erbakan started his political activity through which he managed to be elected to parliament as an independent candidate from Turkey's most conservative city, Konya. In Turkey, major political party leaders have always chosen either their hometowns or Istanbul as their preferred place to pursue political office. Erbakan broke from this tradition in a highly symbolic and successful maneuver to base himself and his ideology in a traditional setting. Erbakan became an exception in Turkish politics because of his ability to go beyond traditional family ties. His Islamic message enabled him to establish the political movement within the Muslim community, successfully using his Islamic identity in a highly secular political environment. ${ }^{193}$

Erbakan began to use religious identity as a political tactic; he criticized his opponents for their lack of Islamic morals. His main, yet most radical, tactic was to label

\footnotetext{
${ }^{193}$ The appeal of Islamic has always been a natural reaction of discontent with Kemalism. The process did not necessarily emerge with the National View Movement. However, Erbakan was able to speed up the process. The National View Movement was channeling Islamic sentiment rather than creating one. For more see, Yavuz 1997a, 71.
} 
his political opponents "freemasons" or "servants of Zionism." 194 On May 15, 1970 in his first year in parliament Erbakan gave a speech on Turkey's entry into the (then called) Common Market. He argued that the Common Market was a Zionist project. ${ }^{195}$ He was aware of the effectiveness of these images in uniting people behind him. This tactic was especially important for him because it gave him quick results, which motivated his party more than the religious messages grounded in Naqshbandi teachings. After becoming an independent lawmaker in 1969 , he was able to mobilize people from within political networks and among ordinary citizens which were dissatisfied with the failed policies promoted and institutionalized by the business and political elites.

Increasingly, these activities became the base of a separate movement, National View, which Erbakan centralized under his leadership. Erbakan established the National Order Party (Milli Nizam Partisi, MNP) in 1970, and in each successive decade he would establish and act as leader for political parties that were extremely influential players in Turkish politics. ${ }^{196}$ For example, after the 1971 military intervention, the MNP was banned from politics so the next year Erbakan established National Salvation Party (Milli Selamet Partisi, MSP). Erbakan's movement was beginning to be called Selametciler (Salvationists) because the MSP became influential when it got $12 \%$ of the general vote in the 1973 elections.

Dedicated to being the voice of the Muslims in the parliament, Erbakan's party later alienated the Muslim constituency, which he had helped build around a political

\footnotetext{
${ }^{194}$ Landau 1996, 298.

${ }^{195}$ He expressed his ideas later in a book. For more see Erbakan 1971.

${ }^{196}$ Dagi 1998.
} 
project. Muslim constituency did not identify with Erbakan's constant appeals to the "usthem" dichotomy. Especially, leading Members of the Nur community who originally were active members of the National Salvation Party began to have problems with Erbakan's political methods. ${ }^{197}$ For example, Erbakan's relations with parties on the other side of the political spectrum were unacceptable to the Nurcu bases. After the 1973 elections, Erbakan formed a coalition government with the Republican People's Party, the most secular party in Turkey and long-time representatives of Kemalism. The coalition with the Republican People's Party, however, was not intended to be a rapprochement between the seculars and the Islamists. It was simply a short-term political maneuvering. Later the coalition became a point of contention between the Republican People's Party and the National Salvation Party when the parties accused each other for the failure of the government.

After Nurcu members left the National Salvation Party, they began to support Demirel's center right Justice Party. ${ }^{198}$ Demirel was a charismatic figure and was also able to get support from another major religious order, the Süleymancis. ${ }^{199}$ The competition for support of Islamic movements caused a stir of competition among political parties for its electoral power. Erbakan mainly stuck to his Naqshbandi wing,

\footnotetext{
197 The open letter that Nurcu members wrote to Erbakan shows how leading members of an Islamic community react to another Islamic leader on religious grounds.

${ }^{198}$ The support of the Nur leaders for Demirel in the absence of Said Nursi created tension between the 'elder brothers' and Fethullah Gülen a new representative of the younger generation. Fethullah Gülen was a minimal figure within the Nur movement at the time however his reaction to political manoeveirng was so harsh that he left the Nur movement and initiated his own community which was later named after him. Gülen wanted Nur community politically independent from influence of any political party including.

${ }^{199}$ Founded by Süleyman Hilmi Tunahan, the Süleymancis were a major offshoot of Naqshbandi tariqah. The highly knitted community of Süleymancis has been constantly supporting Demirel's parties or parties favoured by Demirel.
} 
however, when he claimed to exclusively represent Islam in the political arena, his claim became a rather dividing factor within the overall Islamic community.

The most important question surrounding Erbakan's movement was the nature of his relationship with the Naqshbandi order of Mehmed Zahid Kotku. Because Erbakan's political involvement began with Kotku's direct confirmation and support ${ }^{200}$, many assumed Erbakan's parties was representative of Islam. Kotku's aims were similar to any other major social religious movement in Turkey. He aspired to contribute to the creation of a religious society headed by a political leadership more respectful to the religion. Like his predecessors ${ }^{201}$ Kotku wanted the state to coexist with the society without directly interfering in the religious realm. As a leader of a tariqah, Kotku felt that the state apparatus was completely incapable of developing a pious believing Muslim through social policy. For him only an incremental evolution towards higher levels of religious belief, as promoted by the tariqah system could make a person true believer. Initially, his goal was to form a political party that will be the voice of Muslims in the parliament in order to make the state respectful to the Muslim rights. Like many, he was aware of the fact that the state's tolerance towards Islamic movements would create the social context necessary for active Islamists to teach and guide the believers. Kotku's ideas in this sense aresimilar to Said Nursi's. ${ }^{202}$

\footnotetext{
${ }^{200}$ A close student of Kotku, Korkut Özal was highly involved with the party process. In his book, he explained the support of Kotku to Erbakan. Before 1980's with the dissatisfaction of Erbakan, Korkut Özal ran against Erbakan. For more see Özal 1994.

${ }^{201}$ Especially Khalid al-Baghdadi.

${ }^{202}$ In his autobiography, Said Nursi argues that state and its officials are "servants of the society." Therefore he argues that although a Muslim/Islamic state is desirable a non-Muslim state is acceptable too. See Nursi 1996, 79.
} 
There was another difference between Erbakan and the Naqshbandi movement. The political identity of the Naqshbandi movement was not formulated in contrast to an alien ideology, political party or institution. The Naqshbandi order has always articulated its teachings on the basis of a conservative reading of the Quran and hadith. Moreover, Kotku maintained contact with the leaders of all major political parties, including centrist Demirel, who happened to be the major political rival of Erbakan, and Alpaslan Türkeş, who was an ultra-nationalist ideologue who mixed ideology with religious symbolism. ${ }^{203}$

The semi-openness of the proselytizing activities of the Naqshbandis contradicted Erbakan's exclusive concern with political power through electoral victory. As a result, the Naqshbandis began to be dissatisfied with Erbakan. His short-term coalitions with hard-line secularists for short-term political gains were also unacceptable in their eyes. They were open to political parties on the right; however, leftist parties like Republican People's Party were constantly anti-religious, which made it unacceptable for Naqshbandis to associate with them. Basically, the Naqshbandis wanted political activism to be an extension of social consciousness and not the creator and controller of society. Therefore, they wanted self-professed Islamic parties to act in accordance with Islam, and make their commitment to the parliament or other political institutions secondary.

In the 1977 elections, Erbakan's vote declined from $12 \%$ to $9 \% .{ }^{204}$ On one hand, this shows that Erbakan was already beginning to alienate his religious constituency by

\footnotetext{
${ }^{203}$ Yasar 2004.

${ }^{204}$ See Jenkins 2008.
} 
being overly aggressive. ${ }^{205}$ On the other hand it shows that Erbakan's movement was able to mobilize $10 \%$ of the population on a consistent basis. Because of this Erbakan was able to gradually become more or less independent from the social movement that had been his initial base for his early business and political activity. Eventually he alienated Kotku and began to distance himself from Erbakan's party in public, and in private he spoke critically of Erbakan, but was never taken seriously. Erbakan allowed Kotku to be discontent in private as long as he was able to rely on his religious followers for easy votes. Therefore, he maintained a low profile, and following a "wait and see" approach that worked to his benefit. Erbakan kept his position in the movement while the old charismatic religious leader, Kotku, passed away leaving in his place a lesser figure his son-in-law Esad Cosan. ${ }^{206}$

After the 1980 military coup, Erbakan and his party were banned from politics once again but this time by the military rule. However it did not diminish the popularity of Islamist political parties. After the military government, Erbakan established the Welfare Party. It became a major player in the post 1980 political arena. Until 1987, due to the ban on Erbakan, his close associates took control of the organization of the party. Traditional Islamic communities during the military's rule preferred to continue their low profile religious activities on the societal level. This factor was emblematic of the differences between the traditional tariqah and the newer, younger National View Movement founded by Erbakan.

\footnotetext{
205 The first major division in the party happened when M. Gündüz Sevilgen representing the Nur community left the party with his sixteen friends, right before the 1977 election.

${ }^{206}$ Yasar 2004.
} 
With Erbakan in sole control of the political party, their official rhetoric became more anti-state and anti-western, similar to Islamist movements in the Middle East. ${ }^{207}$ There are two major reasons for this surge in spiteful political language. First, Erbakan started to become aware in the early 1970s that his method was successful in uniting the discontent masses behind his leadership against corrupt parties who "imitate the west". ${ }^{208}$ If he had moderated his language, his party would not have been able to distinguish itself from centrist moderates. With strong religious and anti-western rhetoric Erbakan presented himself as an alternative to the prevailing centrist parties who had been ineffective and corrupt. A second factor might be found in the Iranian revolution and Russian invasion of Afghanistan. In Turkey Erbakan was the first to bring Islam into mainstream politics; he had no local precursors, so he imitated Middle Eastern countries where political movements gained more power than the Naqshbandi grass root Islamic movement. In order to save the ummah he envisioned a religious movement led by populist political leadership. After 1980s, the influence of the Middle Eastern Islamist literature and the Iranian revolution added to his desire for strict control of the general Islamic movement.

After the military rule, civilian authority was resumed and Turgut Özal ${ }^{209}$ came to office in 1983. Due to the ban on his leftist opponents, Özal was able to unite the center right and Muslim votes under the banner of his newly founded Motherland Party (Anavatan Partisi, ANAP). His ban on certain parties that were initially banned during

\footnotetext{
${ }^{207}$ Dagi 1998.

${ }^{208}$ Erbakan's same discourse go back to as early as 1970. For more see Erbakan 1970.

${ }^{209}$ At the time, Turgut Özal's previous links with the Naqshbandi community were not well known.
} 
military rule could not remain in place because people wanted the freedom to form parties true to their desires. He approved the referendum which lifted the ban on Erbakan and many other major figures in 1987. From 1987 until the mid 1990s Erbakan's new Welfare Party was able to show only small signs of success in local and national elections. However, it was in the local administrations that the Welfare Party gained popularity throughout the country. In 1994, the party won an overwhelming percentage of votes in town, city and county elections. The Welfare Party garnered a major political achievement in the municipal election of March 1994 when the Refah party won the mayoral elections of Turkey's two largest cities, Istanbul and Ankara. Its electoral success in 1994 was followed in December of 1995 in the general election. Between these two elections the Welfare Party's image among the public changed from a "marginal" political party to become a nationally recognized political movement. ${ }^{210}$

Recep Tayyip Erdoğan, the future Prime Minister of Turkey, won the Istanbul County elections and became the new, young and energetic face of the Welfare Party as a pseudo-Islamic party. Erdoğan's success was both a result of prior success and a cause of the Welfare Party's future accomplishments. His election was initially a result of Welfare Party's name recognition. Later his skill and aptitude in solving Istanbul's chronic water and environmental problems solidified the Welfare Party among the electorate.

Welfare Party was able to get the most votes in the 1995 general elections, with over $21 \%$ of the general vote. Itwon 158 seats in the 550 -seat parliament. Welfare Party tried to form a coalition government with other centrist secular parties, the Motherland

${ }^{210}$ Önis 1997, 743. 
Party $^{211}$ and the True Path Party (Dogru Yol Partisi, DYP), but they opted out of a coalition with Erbakan and built a coalition with each other. Historically rival parties Motherland Party and True Path Party formed the coalition under Motherland Party's leader Mesut Yilmaz, as Prime Minister, and True Path Party's leader Tansu Ciller as his deputy. This coalition later disintegrated amidst corruption charges. Ciller left the ANA$\mathrm{YOL}^{212}$ coalition and formed a new coalition government in June 1996 with Erbakan in exchange for pardoning the charges against her in the parliament.

Ciller was suspected by many of corruption and bribery because of her unaccounted and conspicuous wealth. Also during the previous election campaigns, she attacked some conservative Muslim politicians with the terrorist label. Though she was an unlikely partner, Erbakan used her seats in the parliament to form a coalition government. His policy, since 1973, was based on political pragmatism and bridge building. This was not welcomed by the Naqshbandis and those who voted on the basis of Islamic identity. With the support of Ciller, secular Turkey had its first islamically oriented party since the founding of the republic. Ciller was subjected to harsh criticism from secular circles for this alliance, but this was the only way for her to protect herself from prosecution. ${ }^{213}$ Erbakan became the Prime Minister and Ciller Minister of Foreign Affairs and Deputy Prime Minister. With the support of Erbakan's party corruption charges against her were dropped in the parliament. ${ }^{214}$ Abdullah Gül who later became

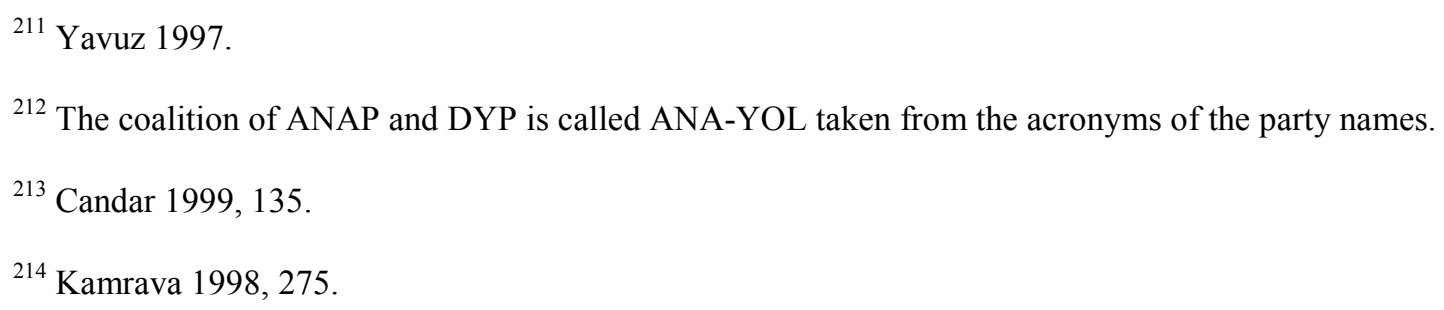


the President on the Justice and Development Party ticket in 2007 became, speaker of the cabinet while Recep Tayyip Erdoğan, outside of the cabinet, was the mayor of Istanbul.

Erbakan's foreign policy was, at least symbolically, directed towards the Middle East and Muslim countries. Contrary to established foreign policy, he made his first foreign visit to Tehran to meet with then President Muhammad Khatemi. ${ }^{215}$ The result of his trip was a $\$ 20$ billion deal with Iran to import natural gas. ${ }^{216}$ Erbakan used other occasions to promote his agenda in foreign relations and initiated the D-8 summit in his first year. D-8 stands for the union of eight developing countries. All the members are Muslim majority countries, which made Erbakan's project, at least for the opponents, an islamic union. The members of D-8 are Turkey, Iran, Pakistan, Bangladash, Nigeria, Indonesia, Malaysia and Egypt; they are already members of Organization of Islamic Conference (OIC). Some of the party members supported D-8 as an alternative to EU. ${ }^{217}$

Erbakan considered it risky to align solely with the trans-Atlantic countries. His visit to oil rich Iran and establishing D-8 were attempts to diversify the foreign policy options available to Turkey. However, he was never able to explain the benefits of these policies in terms of Turkey's national interests. Erbakan's policies appeared to be a useless deviation from mainstream thinking rather than an improvement of it. His foreign policy choices did not leave a positive impression on domestic or international observers. An example of this failure was his visit to Libya. The visit was a total fiasco. In front of the press, Muammar Gaddafi publicly humiliated the Turkish government because of its ${ }^{215}$ Robins 1997.

${ }^{216}$ Bozdaglioglu 2003, 134.

${ }^{217}$ Aral 2005. 
treatment of Kurdish people. Erbakan's silence turned the majority of the public opinion against him. The Libya trip was a major problem for the members of Erbakan's own party too. ${ }^{218}$ In an attempt to balance Erbakan's pro-Islamic policies, the Turkish military, unilaterally, began to establish relations with Israel in an unprecedented way. ${ }^{219}$ As a result, during Erbakan's tenure, military involvement in politics increased. Cevik Bir, Deputy Chief of Genenral Staff, openly called Iran and Syria the main threats to Turkish security. He argued that it is the Turkish-Israeli cooperation that stabilizes the region against the terrorist threats (of these countries). ${ }^{220}$

An event organized by one of Erbakan's mayors in the city of Sincan in the suburbs of Ankara caused a major problem for Islamists. It was organized around an important foreign policy issue for Muslims. With the help of the Iranian Embassy in Turkey the Mayor of Sincan organized "Kudus Gecesi" (Jerusalem Night) to show solidarity with the Palestinians. During the program pro-Hamas slogans were chanted and the Iranian Ambassador gave a speech. Secularists saw this as an Islamist threat to the secular state. A few days later local tank divisions rolled into the streets of Sincan, making a direct warning to the Islamists. Tensions between the military and the Islamist government were at their highest during the monthly National Security Council meetings. These meetings were constitutionally arranged and semi-binding events held between the Government and the Army. The meetings are organized by the secretariat

${ }^{218}$ Feroz Ahmad stated that disastrous Libya visit marked the beginning of a possible coup. See Ahmad 2005, 170 .

${ }^{219}$ Bacik 2001.

${ }^{220}$ Bir later gave a lecture in the Washington Institute for Near East Policy on October 261999 and published his ideas in the same line. See Bir and Sherman 2002. 
which is held by an Army general and headed by the President. In the February 28, 1997 meeting, the National Security Council advised the government by means of a binding resolution that took very harsh measures against religious practice. ${ }^{221}$

The National Security Council resolution included both symbolic and practical measures. During this era Islamism was declared, by the military, a greater threat than the PKK (Kurdistan Workers Party), which is a terrorist group who is responsible for killing over twenty thousand civilians. ${ }^{222}$ The NSC asked the government to enforce a secular dress code in government buildings and universities. This was the beginning of what has transformed into a controversy over the headscarf in Turkey. Secondly, and most importantly, the February 28 resolutions transformed the educational system in Turkey in its entirety. Primary school education was extended from five years to eight years. From the outset this was an educational reform program that in its essence sought to limit the influence of religion in the public schools. This decision resulted in the closure of general vocational high schools as well as Imam-Hatip schools (for imams and preachers; they are the leading institutions for religious education in Turkey). The military junta of 1997 curtailed all and more of the religious freedom introduced after the 1980 military intervention. Throughout his political career, Erbakan was open and supportive of the Imam-Hatip schools and religious education. However, the pressure put on him by the military establishment forced him to act out of character.

\footnotetext{
${ }^{221}$ Yavuz 2000.

${ }^{222}$ Jacoby 2004, 150. This has been an important example of securitization. See Buzan et al. 1998.
} 
The ban on religious education was not limited to public Imam Hatip schools; it applied to Quranic schools as well. Quranic schools were not part of the mainstream education system in Turkey. Religious foundations responsible for educating hafiz (preservers: those who memorize the entire Quran by heart) usually ran the Quranic schools. Like Imam Hatip schools, Quranic schools were the main centres where Islamists had strong control. Their students were able to pursue both secular and religious educations. For instance, students at these schools generally did not attend the regular schools but were able to obtain a diploma by taking the standardized exams at the end of the school term. In this way, Islamists were able to isolate their kids from the influence of the government curriculum which due to a measure passed during February 28 processprohibited religious education to children before they entered high school. On the other hand, Quranic education was limited to government-controlled courses which were only offered during the summer term.

Though Erbakan attempted to placate the army and the secular bureaucracy his passivity had the opposite effect. In May 21, 1997, the state prosecutor filed a motion to close the Welfare Party; it was accused of anti-secular activities. Erbakan and his coalition partner, Ciller, began to discuss whether they should change positions, Erbakan becoming deputy Prime Minister and Ciller taking over the Prime Minister's office. However, there was a growing dissatisfaction within the Muslim community, including Erbakan's National View, over the new anti-religious laws and the fact that Erbakan had compromised the interests of his constituency in order to maintain power. They considered the secular bureaucratic campaign against them as a serious threat to their identity. Erbakan had assumed that the threat was only to his position in office. 
His constituency was more concerned with preserving some of the gains in religious freedom made over the past few decades than with the position of the party's leader. For example Abdullah Gül, who later left Erbakan's movement and formed a new party, ${ }^{223}$ in an interview said that he warned Erbakan and his associates not to sign the 28 February resolutions. Gül and others would have preferred for them to resign their government positions in protest of military coercion. ${ }^{224}$ However, Erbakan did not want to leave office until the very last moment. Eventually Erbakan's government resigned from the office in June 18, 1997. Confronting the possibility of the party's closure, Erbakan's attorney Ismail Alptekin established a new party, Virtue Party in December 17, 1997. In January 16 1998, the Welfare Party was closed and its leadership banned from politics for 5 years. The Welfare Party was the third party associated with the Islamic National View Movement that was closed by the constitutional court.

This moment marks the beginning of changes for Islamic parties in Turkey. The Virtue Party replaced the Welfare Party but at the time it was not clear who should lead the party because Erbakan was banned from politics. The general tendency in the movement was to follow Recep Tayyip Erdoğan's leadership. Erbakan, who unwillingly approved Erdoğan's earlier bid for Istanbul Mayor, rejected this option. He did not want the party to have a charismatic successor capable of overshadowing him. Erdoğan's record in Istanbul as an independent leader, rather than a loyal follower of Erbakan, threatened to marginalize the party ideologue. Erbakan had earlier disapproved the candidacy of Erdoğan for the Istanbul Mayoral position; it was only as a result of the

\footnotetext{
${ }^{223}$ He later became the Prime Minister and is currently the President.

${ }^{224}$ Selim 2002, 68.
} 
appeals from the Istanbul branch of the party that Erbakan accepted Erdoğan's candidacy. This time Erbakan did not bow to pressure. Eventually an old associate of his, Recai Kutan, became the leader of the party. The party fell into chaos again. ${ }^{225}$

Due to his mayoral responsibilities Erdoğan was not involved in the party management, but his influence was beginning to surpass his official position. Many scholars overemphasize Erdoğan's leading role in the opposition movement against Erbakan. However, it can be argued that Abdullah Gül was the main oppositional figure. Immediately after the establishment of the Virtue Party, Abdullah Gül started to assert his personal style within the party and among the discontented members of the party. Some critical issues increased the division between Erbakan and Gül's supporters. Although Erbakan was banned from politics he did not want to lose his control of the party. ${ }^{226}$

This frustrated the younger generation who wanted to change the party's confrontational tactics. This new generation, who wanted to reform the ideological content of the movement's message, are known as the "reformists" (yenilikciler). ${ }^{227}$ The revivalists within the party were fond of and respectful towards Abdullah Gül; he had always been known as a soft spoken, polite and respectful of the 'establishment.' But after the military coup and the co-optation of Erbakan, Gül began to voice the discontent of the younger generation. At the time nobody ever imagined Gül would one day be the Prime Minister or President of Turkey.

\footnotetext{
${ }^{225}$ Selim 2002, 74.

${ }^{226}$ Selim 2002, 81.

${ }^{227}$ The old generation who wanted to stick to the essentials under the unquestioned leadership of Erbakan is called the "traditionalists" (gelenekciler).
} 
Gül was born in 1950 in the city of Kayseri in Central Turkey. Kayseri is famous for its flamboyant business environment, rich businessmen and Muslim culture. ${ }^{228} \mathrm{He}$ went to college in Istanbul and majored in Economics. He did his MA and PhD work under Sabahattin Zaim, a famous Muslim professor of labor economics. Zaim was a scholar whose students later played major roles in Turkish politics. For example, with his support Gül went to London to pursue graduate research. ${ }^{229}$ Although Gül entered his political life in Erbakan's party, his earlier life was dedicated to the mainstream Muslim communities. However in the case of Abdullah Gül and many other members of new political elite who established Justice and Development Party, its is an understudied fact that these people do not come from one ideological block. ${ }^{230}$

After finishing graduate studies, Gül returned to Turkey and began teaching economics in a newly founded state university in Sakarya, near Istanbul. After 1983, Abdullah Gül left academia and joined the Islamic Development Bank (IDB) located in Saudi Arabia. IDB is organized under the Organization of Islamic Conference which represents Muslim countries in the UN. In 1991, Abdullah Gül joined the Welfare Party and promoted their policies in his hometown Kayseri. He held important positions both in

${ }^{228}$ Selim 2002.

${ }^{229}$ He was sent to Great Britain with a scholarship from a Muslim foundation that aimed to send Muslim students abroad to pursue graduate studies. The activities of foundations like this were not connected with Erbakan's Islamist National View Movement.

${ }^{230}$ More than anybody else it was famous Turkish poet Necip Fazil Kisakurek (d. 1983) who was the major source of inspiration for many like Abdullah Gül and Recep Tayyip Erdoğan. One major detail is also important about Kisakurek's life: he has never been part of Erbakan's movement. Kisakurek was an ardent supporter of grassroot Islamic movements that aimed educating the people. Besides writing, Kisakurek spent his life by giving lectures throughout Turkey. His works, which are considered now as the best examples of Turkish literature, became available in public school curriculum only after Turgut Özal became Turkey's Prime Minister in the 1980's when Kisakurek had already passed away. 
the party and the government. Due to his European and Middle Eastern experiences, he came to represent the party in the international arena. His image as a soft spoken moderate Muslim leader was an asset to the Welfare Party. Before he became the rising voice of the opposition in the party, Gül articulated the National View Movement's foreign policy.

In the April 18, 1999 elections, the Virtue Party received only $15 \%$ of the general vote, an almost 30\% decrease. Abdullah Gül and his friends blamed the party administration for the failure in the elections. In the first party congress Abdullah Gül, who was forty years younger than Erbakan, challenged one of his candidates and openly declared his candidacy for the party leadership. It was unheard of within the Welfare Party to contradict Erbakan; party members had become accustomed to Erbakan dictating policy by fiat rather than consultation. Erbakan and his close associates had become elitist, viewing themselves as the leaders of the Islamic community. Erbakan identified the interests of the nation and of Islam in general with his personal rise to power. His previous term in office demonstrates the danger of identity politics and an excessive reliance on the state.

Erbakan, although, came from a traditional, mosque-based Tariqah approach when he was forced to make a choice between the needs of religious Muslims and his own position he chose the latter. ${ }^{231}$ However, the reformist generation within the party gave primacy to the needs of the masses, used milder language and strategies, and actually promoted Islamic identity. Abdullah Gül rose as a leading figure among the

${ }^{231}$ Famous Islamic poet Necip Fazil has similar ideas. Kisakurek 1998. 
dissatisfied within the party while Erdoğan supported him from outside. Apparently, ordinary members of the party welcomed Gül's method. However, Abdullah Gül still lost the election to Recai Kutan by a count of 633 votes to 521 votes.

After the elections in the party congress, the divide between so-called traditionalists and reformists increased. The traditionalists tried to marginalize the reformists from influence in any post. No reformist, or non-loyalist of Erbakan and his allies, was given any administrative positions. The unexpected success of the reformists was a major threat to the party elites who tried to clean the reformists from the party ranks before the next election so that these dissidents could not join the parliament. It was the first time the National View Movement had such large scale opposition within the party. ${ }^{232}$

However, in June 2001 the Constitutional Court closed the Virtue Party, the fourth political party of the National View Movement. After the closure of Welfare Party, nobody expected a ban on the Virtue Party, which appeared to be substantively different from its predecessors. The reason for this legal action by the state was that Erbakan, though legally banned from politics, was involved in inner party disputes on behalf of his associates. Right after its closure, under the auspices of Erbakan, members of the National View Movement established the Felicity Party (Saadet Partisi, SP). At this point, the question remained whether the reformers who had lost the party congress to the traditionalists would join the new party? But tensions among the parliamentarians of the former Virtue Party was increasing. Consequently, in August 2001 Erdoğan and his

${ }^{232}$ See Murat Mercan's ideas in Robins 2003a, 550; Robins 2007a, 300. 
followers established the Justice and Development Party and fifty-two lawmakers of the banned Virtue Party joined the Justice and Development Party.

In the party meetings in and around city of Fatih, which was traditionally Naqshbandi and pro-Erbakan, many previous National View Movement members who had just joined Justice and Development Party needed to give an explanation because, until then there were no major public signs of dissatisfaction among party members against Erbakan. It was the first time many members learned the inner workings of the party. Some began to debate about how Erbakan was able to create a base of loyal followers. In one of the meetings, one Justice and Development Party member specifically told the audience how the myth of "mujahid" Erbakan was created within the National View Movement. He said that all the party members thought Erbakan was involved in a sacred struggle. This idea gave Erbakan unquestioned legitimacy in the face of criticism. Just like other charismatic leaders Erbakan became autocratic. The negative tactic of formulating identity in contrast to an imaginary "other" was the essence of his political style. Within the discourse of party members Erbakan directed his criticism and anger at the west, the United States, or Israel. This tactic gradually socialized National View Movement members into the politics of fear and identity. When members from within the party questioned his decisions, such as the anti-religious laws he supported, he had them branded as traitors and enemies.

Erbakan's method was more appealing than the Naqshbandi method which was losing its influence especially among the new generation of young Muslims. Those who were fed up with the Kemalist system wanted a quick revolution. Traditional tariqahs emphasized gradual change, first of the individual, and then of his environment. 
Erbakan's method was typical of mass movements under strict control by an elitist cadre. The unquestioned nature of shariah is blended with political issues so that the holders of sacred positions who serve shariah could deflect criticism onto a constructed foe or just claim authority based on the cause.

Four former members of National View Movement mainly led the Justice and Development Party: Abdullatif Sener, a successful finance professor and long time activist; Abdullah Gül; Bulent Arinc, a leading figure in the movement and friend of Erbakan; and, Erdoğan, former mayor of Istanbul, who had just finished a prison sentence for political reasons. Erdoğan was mainly active in the Istanbul branch. The other three major figures were active in National View Movement party headquarters, close to Erbakan. Although Erdoğan was famous within the National View Movement, his name became well known publicly only after he came to the office as the mayor of Istanbul. Istanbul, with its 14 million residents and major businesses, has been the heart of the Turkish economy.

When Erdoğan began to successfully address the major issues of this metropolis, his popularity soared and he became a household name. Erdoğan was distinguished on the basis of his ability and merit. Turkish voters, especially the younger generation, wanted a leader that was capable of solving problems and not self-absorbed, like Erbakan, or corrupt, like his predecessors. Although the other three leaders were well regarded within the party, they all came to an agreement on Tayyip Erdoğan's leadership. With his charisma, Erdoğan was able to win the support of the new party members and a significant portion of the electorate in the next election campaign. Six months after its 
establishment, in the November 2002 general elections, Justice and Development Party came to power with over $34 \%$ of the popular vote.

For many scholars there are not many differences between Erbakan and his former students. In one of his old speeches Tayyip Erdoğan said "Our mission is not one simple-minded fight or world conquest; it is to spread and promote the rule of the religion of Allah. The first condition of this mission is peace and concord." Serif Mardin interprets this speech as "cautiousness related to the banning of Islamist organizations by the military regime established after the 1980 coup."233 The Justice and Development Party has had to deal with these types of suspicion since the day it was established. Opponents asked the same critical question: is Justice and Development Party different from Islamist National View or is it practicing taqiyya (dissimulation)? Will Erdoğan, as in Algeria and Iran cases, pose a threat to the democratic system? Will he turn Turkey into a fundamentalist theocratic state? To answer this question we need to focus on his personal and political Erdoğan.

Recep Tayyip Erdoğan was born in 1954 in Istanbul. His father was a devout Muslim. Erdoğan was born in the Islamic month of Recep (Rajab). Therefore, his father named him after this holy month. ${ }^{234}$ Erdoğan's family was from Rize, a black sea region town known for its conservative-Muslim population. Financially, Erdoğan's family was underprivileged; therefore, until his college years, Erdoğan worked for street vendor selling water or traditional Turkish donuts. He went to the Imam Hatip Schools. Many

\footnotetext{
${ }^{233}$ Mardin 2006.

${ }^{234}$ Among the practicing Muslims of Turkey, it is a common practice to name children after the holy months and nights. Islamic holy months of Rajab, Shaban, Ramadan, Shawwal and Muharram are commonly used names together with holy nights like Qadr and Baraat.
} 
practicing Muslim families preferred Imam Hatip schools which are funded by the government. These schools are originally intended to educate prayer leaders in the mosques in line with government interests. Erdoğan's political life began in high school, where he was involved passionately in the National View Movement activities. He was the head of the High School branch of the National Turkish Students Union (Milli Turk Talebe Birligi in Turkish, MTTB). ${ }^{235}$ MTTB has widely known for its Muslim student activities.

Although he attended Islamic school, in college he did not pursue a career in theology. In college, he attended to the Management department of Marmara University in Istanbul. In his college years, he was active in party politics. Right after college, he entered into business life with a prestigious company while continuing his political activities in the National View Movement. He had a successful tenure in city and county offices of the National View Movement. In the 1980s he helped to increase the influence of National View Movement's Welfare Party among different segments of society. Istanbul was his political arena and he managed his conduct and professional life in such a way that he became appealing to all segments of society, not just those who practiced Islam or embraced identity politics. He was a major reason for the success of the National View Movement in the 1990s.

The rising star in politics at the time, however, was Turgut Özal, another Naqshbandi turned politician. Previously, Özal was a successful undersecretary of the Prime Minister in charge of economic affairs. Coming from the Naqshbandi background

\footnotetext{
${ }^{235}$ Interestingly enough Abdullah Gül who is slightly older than Erdogan and was the head of the college branch of MTTB.
} 
he and his brother Korkut were active in political life. Because of their religious background, the Özal brothers were known as "brothers wearing takunya" (takunyali biraderler). Takunya, a traditional wooden sandal, is mostly used in mosques to get ablution before the daily prayers. The Özal brothers openly practicing their religion, used to wear these sandals and noisily walk through the hallways of the government offices making everybody hear that they are getting ready for the daily prayers.

The military was aware of his religious character, the international and financial expertise of Özal made him indispensible to the military government of the 1980. As a result, he continued to work as the top bureaucrat in charge of economic affairs. A few years later, Özal left the government and decided to run for Prime Minister. With years of government employment and international experience, the Özal brothers were more pragmatic than the ideologically committed Erdoğan at the time. Later, Turgut Özal's younger brother Korkut played an advisory role to Erdoğan after Erdoğan established Justice and Development Party. ${ }^{236}$ During the 1980s, Erdoğan and Erbakan contrast sharply with the Özal brothers, though both of them come from the same Naqshbandi background. ${ }^{237}$ The Özal brothers had more government experience than the Erbakan and Erdoğan. As a result, the pragmatic Naqshbandi members supported Turgut Özal's Motherland Party.

Neither of these conflicting political lines, however, was monolithic either. Earlier, Tayyip Erdoğan who was also politically strict had differed from Erbakan in

\footnotetext{
${ }^{236}$ For more on Özal see Barlas 2000. Barlas was a leftist-communist turned liberal who became sympathetic to Muslims due to his relationship with Özal.

${ }^{237}$ Cornell 1999, 213.
} 
many areas. This was especially noticeable when he became the party president in a highly cosmopolitan district of Beyoglu in Istanbul. Beyoglu has traditionally been the "French Quarter" of the city. It hosted the Consulate of France, semi-private French High schools and more importantly historic churches and synagogues with their congregations. On the other hand, Beyoglu has been a hub for not only the religious minorities but also the entertainment center for the secular Turks with pubs and bars spread throughout the historic neighborhood.

When Tayyip Erdoğan began working in Beyoglu, his party base was literally nonexistent among the residents. After successful campaigning by paying visits to bars and pubs and getting in contact with the religious minorities, Tayyip Erdoğan was able to make his party one of the most appealing ones. He lost the Beyoglu city election with a slim margin and was able to popularize his name among his supporters and party officials as a successful leader who could win votes from a variety of voting blocks. This was the primary difference between him and Erbakan. He continued as the president of the Welfare Party in Istanbul and prepared for the coming local elections.

As stated before, after long discussions within the party ranks, in 1994 Erdoğan became a candidate for mayor of Istanbul, but Erbakan did not want him to be the candidate from the National View Movement because Erbakan doubted his personal loyalty. With the backing of prominent party members, Erbakan unwillingly made Erdoğan the candidate for Istanbul County. The secular media attacked Erdoğan on religious grounds; the Muslim community supported him because he was their 'fellow Muslim brother'. Islamic communities such as the Nur and Gülen movements, which did not vote for the National View Movement for a long time, openly supported Erdoğan. 
Erdoğan was also able to mobilize the female vote. Contrary to many political parties including his own Erdoğan paid great attention to the women's branch. As long as the new techniques were in line with his moral vision Erdoğan accepted their use on the basis of pragmatism. He revolutionized the role of women in the party; they, in turn, voluntarily visited many underdeveloped sections of the city to ask for support of Erdoğan. As a result, many segments of society, including conservative Muslim families, and others from center right ideologies voted for Erdoğan. With a slight margin, he won the election.

Erdoğan's success helped him win his election campaign. The key to his success was that he managed the administrative tasks of mayor as well as all the public services very efficiently. Before his term in office, there were major problems with air pollution, traffic, water distribution, and garbage collection. As his name became the public recognition for his party, even Erbakan mentioned him to show how successful the party was. However, Erdoğan's relations with Erbakan were not good. Although Erbakan was his leader, Erdoğan wanted to maintain control over his office. He did not let other party members get involved in his job. As he became more independent his relations with Erbakan deteriorated. Erbakan's involvement from above was destabilizing Erdoğan's coordination where he was used to being the sole decision maker.

His popularity increased to such an extent that he soon became a popular public speaker throughout the country. He was invited to party events in the cities where local party officials wanted to attract non-affiliated voters. In one of these events he went to a 
southeastern Anatolian city named Siirt. ${ }^{238}$ The reason Erdoğan attended a rally in Siirt was because his wife's family was from there and he wanted to win the support of the citizens. In the rally, Erdoğan gave a motivational speech where he quoted a poem of the Turkish Poet Ziya Gokalp. Ziya Gokalp was the intellectual father of Mustafa Kemal Ataturk, the founder of Turkey. ${ }^{239}$ The poem later became a part of a major controversy that transformed Erdoğan's political life. The most controversial part of the poem was the following part.

"The mosques are our barracks, The domes our helmets The minarets are our bayonets The Believers our soldiers",240

For Erdoğan it was an ordinary speaking engagement. As usual, he quoted many other poems throughout his speech. For Erdoğan the main connection uniting the people of Siirt and rest of the nation was Islamic identity. However, prosecutors felt that his reference to believers and religious symbols was provocative. They filed a lawsuit against him in 1997, and in accordance with the article 312 of the penal code, in April 1998 he was charged with openly inciting enmity among the people by referring to differences pertaining religion, language and race. For many, this was an attempt by the secular establishment to sabotage Erdoğan's political future. He was sentenced to a term of six months prisonwhich constitutionally barred him from seeking elected office.

\footnotetext{
${ }^{238}$ Siirt is in the southeast Turkey but contrary to most other cities in the region it is not a Kurdish majority city. Arabic descent Turkish citizens make up the majority of the population in Siirt. As the boundaries between Turkey and Syria were drawn by the Allies right after the WWI, the geo-cultural realities often times were disregarded.

${ }^{239}$ On Gokalp's ideology see Yavuz 1993.

${ }^{240}$ Mecham 2004, 345.
} 
Rather than ending his political career, the prison sentence increased Erdoğan's appeal in the eyes of Turks who often sympathize with the victims of injustice. People with centrist leanings began to think positively about Erdoğan because the poem he used was originally published in official school textbooks and widely known among them. The political sentence also heightened Erdoğan's status within the National View Movement; he appealed to a wider audience than the traditional National View Movement constituency. After his prison sentence ended, Erdoğan began to organize with a diverse group of people from different social backgrounds, but mainly former National View Movement members. He called his movement Movement of the Righteous (Erdemliler Hareketi) which later became the Justice and Development Party in July 2001. Fortyeight lawmakers of the Virtue Party joined the Justice and Development Party. ${ }^{241}$

Together with former National View Movement members, the Justice and Development Party organized a coalition of politicians from centrist parties like the True Path Party, the Nationalist Action Party (Milliyetci Hareket Partisi, MHP) and the Motherland Party. It was difficult for Erdoğan to keep the party together in the beginning years. Erdoğan was known as a micromanager and insisted on handpicking each party official. His absolute control caused some early departures, especially from the members who joined the party from other political parties. ${ }^{242}$ Due to the political ban Erdoğan himself was not a member of the parliament. Legally he was allowed to become a party

\footnotetext{
${ }^{241}$ Although the founding members of the Justice and Development Party were critical of the National View Movement establishment, among the public, in the media, and by their political opponents, they were still associated with Erbakan. For more see Heper and Toktas 2003.

${ }^{242}$ Meral Aksener, former Ministry of Interior, who joined the party from the rival Nationalist Action Party, was first to leave the Justice and Develeopment Party arguing that even the city presidents of the party branches were already chosen without consultation or election.
} 
member but not a prime Minister or a lawmaker; yet, he was leading the party during the elections to decide who would rule the country. Under these circumstances, Justice and Development Party attended its first election and won $34.3 \%$ of the popular vote, becoming the first majority party government in almost two decades. Only the Republican People's Party passed the $10 \%$ national threshold.

Due to Erdoğan's political ban Abdullah Gül became the Prime Minister. Gül and Erdoğan were able to cooperate within a party system where authority is generally centralized, though both of them have autocratic temperaments. It was a suprising situation for Turkish political history because charismatic leaders, like Erbakan, never let other charismatic leaders overshadow them. Previously, there were debates about whether Erdoğan would let Gül to be the Prime Minister. Contrary to Erbakan's method of choosing loyal members over competent ones, Erdoğan and Gül proved that they were different from Erbakan where they were able to overcome selfish political desires.

Abdullah Gül's appointment to Prime Minister caused two problems, for the party and the political system. For the party it created a dual leadership between the Prime Minister and the powerful party president. This had the effect of creating double loyalties. The most important problem was for the political system. The main opposition leader was Deniz Baykal, an ardent secularist and opponent of Erdoğan. He declared that he did not want to see the leader of the winning party banned from politics. With the support of Baykal, the parliament amended the constitution and Erdoğan's ban was removed. He was able to run for office again. Six months after the elections Erdoğan was elected to the parliament from the city of Siirt. As soon as Erdoğan was elected Abdullah 
Gül resigned, allowing Erdoğan to become Prime Minister; Gül became Minister of Foreign Affairs and deputy Prime Minister.

After the election, Erdoğan began to visit the capitals of European countries. After he established personal contacts with his counterparts in Europe, he began implementing reforms to democratize the country opening order to help Turkey gain EU membership. The Penal code was changed, legal aspects of human rights problems were improved, and democratic reforms began to be implemented. ${ }^{243}$ Erdoğan's relations with Muslim countries were balanced. For example, he developed Turkey's relations with Greece while also engaging more proactively with Muslim Middle East countries. However, he never used Islam as political message in his foreign policy rhetoric. Contrary to Erbakan, Erdoğan's main priority has always been EU membership. ${ }^{244}$ Erbakan paid his first visit to Iran to symbolize the orientation of his foreign policy. Erdoğan did the opposite, going to Europe to push for EU membership for Turkey. This era marks the highest level of Europeanization and democratization, more so than the Kemalists. ${ }^{245}$ However, during Erdoğan's tenure the debates continued whether he was sincere in the reforms or secretly wanting to pursue Islamic agenda.

In this chapter, I tried to demonstrate that the rise of Erbakan does not necessarily correspond in any substantial way with the gradual Islamization of Turkish society. The division within the party when Nur community and Qadiri tariqah members left

\footnotetext{
${ }^{243}$ Later on, the leaders of EU claimed that they found Erdoğan as the most determinant leader the Turkey in the way to EU. For more on Turkish political parties and their relationship with EU see Parslow 2007.

${ }^{244}$ For more on the EU- National View Movement relations see Taniyici 2003.

245 The bearers of the torch of civilization in the country left empty-handed and transformed into more radical and closed groups that were anti-western if not anti democratic.
} 
Erbakan's party shows how different Islamic communities did have different opinions about the so called Islamic methods utilized in the political arena. Erbakan's success is more representative of a broad public discontent with the other political parties on issues of efficiency, ethics, and corruption. Especially after 1990s, the success of the city mayors (Tayyip Erdogan being the most important one) in local governments contributed to Erbakan's rise as the first Islamist prime minister. His ideological appeal was only a secondary factor in his electoral success in 1995. As his rhetoric became increasingly inflammatory, he lost the political support of the Nakshbendi tariqah and later the nonreligious vote. This eventually contributed to the rise of the Justice and Development Party, who learned from Erbakan the limits of rhetoric in maintaining public confidence. 


\section{Chapter V: NUR AND GULEN MOVEMENTS: HAQIQAH}

In this chapter, I argue that, the Nur and Gülen movements are modernist as well as traditionalists; they seek a middle-way to address problems endemic to modernity. Their traditionalism is based on the belief that the Quran is the last and most complete form of revelation, and as such can guide Muslim. They are modernists in the sense that they engage the changes inherent in modernity and are positive toward scientific advancements; i.e. they do not dismiss modernity in its scientific aspect, but they strongly criticize secularism as a self-professed universal ideology. Nursi wanted to contain the radical intrusion of modernity on Islam by returning to the primary sources of religious knowledge and making them relevant to the modern condition.

Bediuzzaman Said Nursi inspired the most influential Islamic social movement in Turkey. ${ }^{246}$ The movement that has gathered around his ideas has overshadowed the historically dominant Naqshbandi order. There are different variants of this movement. This section will focus on the ideas of Said Nursi and Fethullah Gülen. Although the Gülen community is not recognized by the "Nur" title, both of these movements are commonly referred to as "the Nur community" or "Nurculuk". The Nur community is a spiritual legacy of Said Nursi's interpretation (tafseer) of the Quran; Nursi taught that the Quran is a source of divine light (Nur) that has the power to enlighten humanity. ${ }^{247}$ The

\footnotetext{
${ }^{246}$ Nursi is known as Bediuzzaman which means 'non-pareil of the time'. See Mardin 1989, 23. After the 'Surname Law', Nursi was given 'Unlükul' last name. Unlükul means famous servant [of God]. According to the official records, therefore, Bediuzzaman Said Nursi is called Said Unlükul. Said Nursi, however, has never used Unlükul name.

${ }^{247}$ Vahide 2005b.
} 
books he authored are known as Risale-i Nur (Epistles of Light) ${ }^{248}$, which later became the name of the community: Risale-i Nur community or simply Nur community.

Said Nursi deserves attention because he was able to inspire a movement grounded on purely Islamic values without creating an "other". To understand the development and transformation of Nursi's approach to Islam we need to study the different stages in his life. His life has three important epochs. In the first phase, he was actively involved in politics until his visit to the National Parliament of Ankara in 1922 which was established by Mustafa Kemal (Ataturk) and his friends. This phase is called Old Said (Eski Said). The second era began at the end of the Ottoman Empire and with the rise of the new republic. After he returned to Ankara from Istanbul, Nursi retired from his political activities and began to live a semi-secluded life in the city of Van, while the country was steadily being secularized from the top down. This era is called the New Said (Yeni Said). The "Third Said" Era (Ucuncu Said) more or less corresponds to the beginning of the multi-party era when the Democrat Party (Demokrat Party, DP) won the majority vote against the Republican People's Party in 1950 until Nursi's death in 1960. The Democrat Party promoted tolerant policies towards Muslims and Islam; Nursi openly supported them against the Republican People's Party.

\section{Old Said Era (until 1920s):}

Said Nursi was born in southeastern Turkey ${ }^{249}$ during the turbulent years of the late Ottoman era. His hometown, Bitlis, was a major center for Islamic scholarly research.

\footnotetext{
${ }^{248}$ Initially, Nursi named his books "Kelimat." A Turkish word of Arabic origin Kelimat, means the Words.

${ }^{249}$ There are different accounts of when Said Nursi was born. Conversion problems between three different calendars caused this confusion. Two calendars used during the Ottoman era were Hicri (Islamic Lunar) calendar which was used for religious issues and Rumi (Ottoman Solar) calendar for administrative and
} 
This Kurdish city was second only to Istanbul in the training of religious sciences. ${ }^{250}$ This region was officially named Kurdistan because the majority of the population was Kurdish Muslims. ${ }^{251}$ Nursi was Kurdish and learned Turkish in his late teens long after he mastered in Arabic and Persian, the two major languages taught in the traditional madrasa system in the Ottoman era. Majority of his writings either were originally in Arabic or penned down Turkish by his students. Nursi was born into a Sayyid family that was descendants of the prophet Muhammad. ${ }^{252}$ Being a descendant of prophet Muhammad has been a source of legitimacy for the ulema in the Islamic world in general and the Ottomans in particular. ${ }^{253}$ Vahide states that Nursi's family was members of the Khalid al-Baghdadi branch of the Naqshbandi order. ${ }^{254}$ Therefore Naqshbandi scholars gave him his first informal training in the Islamic sciences, especially the study of

economic issues. After 1926, Miladi (Gregorian) calendar began to be used. By interpreting some information in Nursi's own books, Mardin, Kosoglu and many others argue that Nursi was born in 1873. Sahiner, the most famous biographer of Nursi, argues that Nursi was born in 1876. However, Nursi's autobiography states that Nursi was born in 1877. Most recently, after a detailed analysis, an editorial article in Koprü (a journal published by young generation Nur scholars in Istanbul) argued that Nursi was born in 1878. I take 1878 as the most accurate account. For more see Mardin 1989; Kosoglu 2004, 25; Sahiner 2006, 40; Nursi 1996, 2122; Risale-i Nur Enstitusu 2000.

${ }^{250}$ Mardin argues that students of Khalid al-Bagdadadi branch of Naqshbandi order were instrumental in making the region a hub of Islamic studies. Mardin 2005 [1991]. See also Mardin's book on Nursi where he describes the religious life in and around Bitlis; Mardin 1989.

${ }^{251}$ Bruinessen 1992, 247.

252 Although it is a widely accepted issue among his followers, Hamid Algar contradicts with the "Sayyed"ness of Said Nursi. See Algar 2001.

${ }^{253}$ In one of his famous Hadith (sayings) Muhammad said that his family will descent from his daughter Fatima (wife of Ali and mothers of Husayn and Hasan). For Muslims in general and Muslims in Turkey in particular it is a traditional honor to establish a lineage to the "house of the prophet" known as Al-i Bayt (Ehli Beyt in Turkish). Initially it was an informal declaration however since the later periods of the Ottoman Empire Husayni and Hasani Muslims were officially recorded in government records due to their special tax exempt status.

${ }^{254}$ Vahide 2005b, 3. 
jurisprudence $^{255}$. However, Nursi never became a formal member of a Naqshbandi tariqah. ${ }^{256}$ In spite of the dominance of the Naqshbandi tariqah in the region, he instead insisted on his self-proclaimed spiritual adherence to the teachings of Abdulkadir Geylani. ${ }^{257}$ Nursi often showed a mastery over the traditional curriculum, despite his somewhat attenuated educational career. ${ }^{258}$

In the following years, Nursi pursued a career as a local master teaching while also acting as an arbitrator between the rival tribes in the region. Due to his independent resistance to influence from the religious and political authorities, he was named Mullah Said the Famous (Molla Said-i Meşhur). Because of this reputation, he was able to establish relationships with the local and regional authorities, i.e., governors. Sometime after 1896, Nursi met with Tahir Pasha, the governor of the city of Van. Tahir Pasha's political and official activities informed Nursi about contemporary debates in Europe. He became Nursi's gateway to the political and philosophical discussions in Europe concerning the future of Islam and the Ottoman Empire. ${ }^{259}$ One day Tahir Pasha informed Nursi that the secretary of the British House of Commons made remarks insulting to Muslims, their faith and the place of the Qur'an in their lives. From newspaper clippings that Tahir Pasha showed to Nursi, it became clear that Britain and

${ }^{258}$ Said's education only lasted three months. Serif Mardin says that because he was much younger than his peers were, Said's educational career ended with a controversial graduation ceremony in 1888. Mardin 1982,68

${ }^{259}$ Mardin 1982, 70.
} 
other regional players from Europe would disunite the Muslim world by demeaning Islam and Qur'an as its unifying factor. ${ }^{260}$ Nursi was motivated by the threat that hegemonic powers would attack Islam as a source of identity and empowerment among believers, to study Islam and make the promotion of the faith his life's work. ${ }^{261}$

Despite living in isolation from the large cosmopolitan cities, Nursi was following events both inside and outside of the country. He was informed about the major developments in the world. However, his focus was mainly on the changes within the Islamic world and the activity and perspective of reformist groups. In his book Divan-i Harbi Örfi Nursi states that "my predecessors in this matter (Islamic Unity -Ittihad) are Sheikh Cemaleddin-i Efgani (Afghani), the late Mufti of Egypt [Muhammad] Abduh, from the extremist [Turkish] scholars Ali Suavi, Hoca Tahsin and those who took Islamic Unity as their goals like Namik Kemal and Sultan Selim."262 Similar to Namik Kemal, one of the major figures of Ottomanist thought, Nursi wanted constitutionalism which will bring rule of law, freedom and and most importantly consultation ${ }^{263}$ which he

\footnotetext{
${ }^{260}$ This event happened in the Islamic calendar year 1316 which corresponds roughly to May 1898-April 1899. Necmeddin Şahiner argues that the British Secretary was (William Evart) Gladstone). Şahiner is the main source of this information. For more see Şahiner 2006, 80. However, Vahide, missing almost two years in calendar conversion, argues that 1316 corresponds to the turn of the century which is roughly two years after Gladstone died Vahide 2005b, 358. In line with Vahide's explanation, Nursi probably learned of the remarks of Gladstone sometime after the latter made them.

${ }^{261}$ Vahide 2005a, 9; Vahide 2005b, 359.

${ }^{262}$ Nursi 1996, 1922. Nursi's reference to Sultan Selim is to the Ottoman (Yavuz) Sultan Selim I not Selim III as many other scholars argued.

${ }^{263}$ Vahide 2005b, 59-62.
} 
considered as an Islamic requirement. Sultan Selim, on the other hand, wanted to bring all Muslims under a loosely connected administrative body. ${ }^{264}$

At this time, he realized that the traditional form of Islamic theology (kalam) was incapable of providing guidance and solutions to the challenges facing Islam. ${ }^{265}$ Nursi's followers argue that he did extensive readings in modern sciences at the residence of the governor. For traditional scholars (ulema) of the Ottoman madrasa system this was a challenging reform. ${ }^{266}$ Displeased by the progressive deterioration of the social and economic well being of the people, he began to look for new ways of reforming society via the educational system. In one of his later works, he proposes three primary reasons for the decay of the Islamic world: poverty (fakirlik), ignorance (cehalet) and (civil) unrest-conflicts (ihtilaf). In addition, he proposed three solutions to these problems: science (marifet), art (san'at) and unity (ittifak). ${ }^{267}$

The instrument Nursi intended to use to mediate and solve these problems was an educational institution, a university that could study and enact changes based on modern sciences and religion. ${ }^{268}$ In order to overcome the obstacles in the Muslim world in general and Eastern Turkey in particular he wanted to utilize the positive role of Islam in

\footnotetext{
${ }^{264}$ During his eight-year sultanate, Sultan Selim fought series of wars with neighbouring Muslims countries who held the Islamic caliphate at the time. After winning the wars with Mamluks, Selim became the first Ottoman Caliph who left the administrative responsibilities of the newly conqurred lands to local nobles.

${ }^{265}$ Vahide 2005a, 8

${ }^{266}$ Vahide 2005b, 27.

267 Nursi 1996, 1964.

${ }^{268}$ Nursi said, "The enlightenment of the soul comes from religious sciences. The light of the mind comes from modern sciences". Therefore, he said, "We need to unite [modern] new sciences with the [religious] sciences of madrasas". For more see Nursi 1996, 1955-1957.
} 
society via education. ${ }^{269}$ The problems of ignorance and turmoil in the Muslim world, for Nursi, could only be resolved if people followed religious principles. Nursi wanted to unite regional communities from different backgrounds through the Medresetu'z-Zehra project. Therefore in the new university (in Nursi's words house of sciences, darul funun) education would be in Arabic (vacip, meaning obligatory); Kurdish would be the second language (caiz, meaning permitted) and Turkish would be electives (lazim, meaning necessary). ${ }^{270}$ Although Nursi was in a highly Naqshbandi setting his university project was beyond Naqshbandi imagination which was limited to local madrasas. ${ }^{271}$ The university project was unorthodox, unusually modern flavored ${ }^{272}$ but necessary for Nursi. The reason Nursi produced a "modern flavored" project, however, was because the problems faced by his society were the products of modernity. He was flexible enough to accommodate global challenges within his own educational and cultural boundaries. As a result, after long years of establishing himself as a respected scholar in the eastern parts of the Empire, he left for Istanbul, the capital city of the Ottoman Empire, hoping to meet the Sultan in order to receive funding for his university project. It was late 1907 and Nursi was around 30 years old. ${ }^{273}$

\footnotetext{
${ }^{269}$ Although he considers the importance of a science university valid for all Muslims he specifically mentions Eastern Turkey as the main area for his project. Nursi says "Sark bir darulfununa muhtac" (East[ern Turkey] needs a science university). For more see Sahiner 2006, 152-158.

${ }^{270}$ Nursi 1996, 1956.

${ }^{271}$ Mardin argues that the influential Naqshbandi schools were not able to compete with missionary schools opened in the region by the Protestant missionaries. These schools were intended to support the local Armenian minority who at the time made up slightly less than one third of Bitlis's 400,000 residents. Mardin 1982, 72.

${ }^{272}$ Mardin, 1989, 35.

${ }^{273}$ Vahide 2005a, 4-10.
} 
When Nursi came to Istanbul, he found himself in the midst of debates regarding new ideas of constitutionalism, freedom and westernization. During these years, Nursi was heavily involved in political debates. After the proclamation of the Second Constitution (Ikinci Mesrutiyet) ${ }^{274}$ in July 1908, he gave lectures in support of the declaration of the constitution and the importance of freedom [of thought] for the wellbeing of the Islamic community. ${ }^{275}$ The Second Constitution toppled the famous Ottoman Sultan, Abdulhamid II. Due to his pious life and strong support for Jerusalem and Palestine, he was a hero for many Islamists. However, in the opinion of Nursi, Abdulhamid's authoritarian character precluded him from being considered heroic because his management style was ultimately counterproductive. ${ }^{276}$

He discussed the applicability of constitutionalism and its role in strengthening Islamic unity, and made the additional argument for a renewed focus on education as the most important way of promoting Islam in Turkish society. These discussions resulted in two important books: The Reasonings (Muhakemat) and The Debates (Munazarat), published in 1911 and 1913, respectively. ${ }^{277}$ As a result of his publications and public

\footnotetext{
${ }^{274}$ Widely known as proclamation of freedom (Hurriyetin Ilani).

${ }^{275}$ In Turkish "Mesrutiyet her sahada bir hurriyeti uyandiracakti" (Constitutinalism will awaken freedom in all areas). Nursi 1996, 31. See also Vahide 2005b, 59-64; Nursi 1996, 55-60.
}

${ }^{276}$ Abdulhamid II came to power after the murder of the previous Ottoman Sultan. His life was surrounded by insecurity and strict control. As soon as he took the control of power, he established an intelligence organization and closed the parliament ending Turkey's first parliamentary monarchy regime in 1878 . See Beyhan 2002. Contrary to the conventional scholarship which see Islamists as a concrete block in support of the Ottoman State, many Abdulhamid-era Muslim scholars were against Abdulhamid's "tyranny." For example, Ismail Kara explains in detail the opposition sermons of Tunali Hilmi Bey. See Kara 1999.

${ }^{277}$ In the beginning of a recent edition of The Debates, the publisher's note states that the book was first published in Islamic Calendar 1329 (Hicri) which is 1911 Common Era. However, Vahide and some other scholars argue that that the book was published in 1913. Şahiner argues that The Debates was published in 1910. Şahiner probably confused the book with The Reasoning. See Vahide 2005b, 21; Şahiner 2006. 
appearences, coming from the periphery of power center in Turkey, Said Nursi was quite successful in winning the recognition and respect of two major classes in Istanbul; the scholars and the soldiers/politicians. For Nursi the center of gravity was not necessarily the Ottoman state but the influential players within the state, the scholars and politicians. If he could influence these two classes, he felt, he would ultimately be able to influence the entire society.

His aim was to link developments like constitutionalism, and other specifically modern issues, with the future of Islam. In 1911, he went to Damascus and gave one of his most memorable speeches in the Umayyad Mosque. This famous sermon is called the Sermon of Damascus (Hutbe-i Şamiye). ${ }^{278}$ In the sermon, Nursi explained the reasons for underdevelopment in the Islamic world and offered six solutions to what he defined as six moral and spiritual diseases then widespread in the Muslim world. The six diseases, according to Nursi, were the prevalence of hopelessness or despair in social life (Ye's), the absence of truthfulness in social and political life (Sidkin ... Olmesi), the love of hostility (Adavate Muhabbet), ignoring the bonds that unite and strengthen the believers (Rabitalari bilmemek), pervasive despotism in the lives of people either at home or with other members of society (Istibdat), and the exclusive focus of people on personal aggrandizement (Menfaat-i Sahsiye, egocentricity). ${ }^{279}$

Nursi is distinct from many of his contemporaries in locating the problems of his time atomistically in the misbehaviors of individual human beings as actors rather than the environmental factors like foreign influence. He argued that hederived his cures for

\footnotetext{
${ }^{278}$ Nursi 1996. 1961.

${ }^{279}$ Nursi 1996, 1961-1962.
} 
these social ills from the [pharmacy of] Quran (eczahane-i Kur'aniye), for these diseases first effect the individual Muslim and then become pervasive in society. ${ }^{280}$ The cures Nursi offered are hope $(E m e l)^{281}$, truthfulness and trustworthiness $(\text { Sidk })^{282}$, mutual love among Muslims (Muhabbet), ${ }^{283}$ consultation (Mesveret) ${ }^{284}$ solidarity (Rabita) ${ }^{285}$, and freedom (Hurriyet-i Ser'iye). ${ }^{286}$ The explanations he articulates target individual actors as agents capable of changing the future of the Islamic world. Although Said Nursi preferred a political method to cure society's problems, it is noteworthy to see how even in the Old Said era, Nursi's cures for the diseases in the society are also unit level explanations.

Until the outbreak of the World War I, Nursi traveled back and forth between Istanbul and Eastern Anatolia. While in eastern Anatolia, he defended and explained the inevitability of the developments taking place in Istanbul; while in Istanbul he lobbied for the university project for eastern Anatolia. Before being able to finish his University project WWI began, he became a commander in the army and fought on the Eastern Front against Russian and Armenian forces. ${ }^{287}$ He was captured by the Russians in 1916,

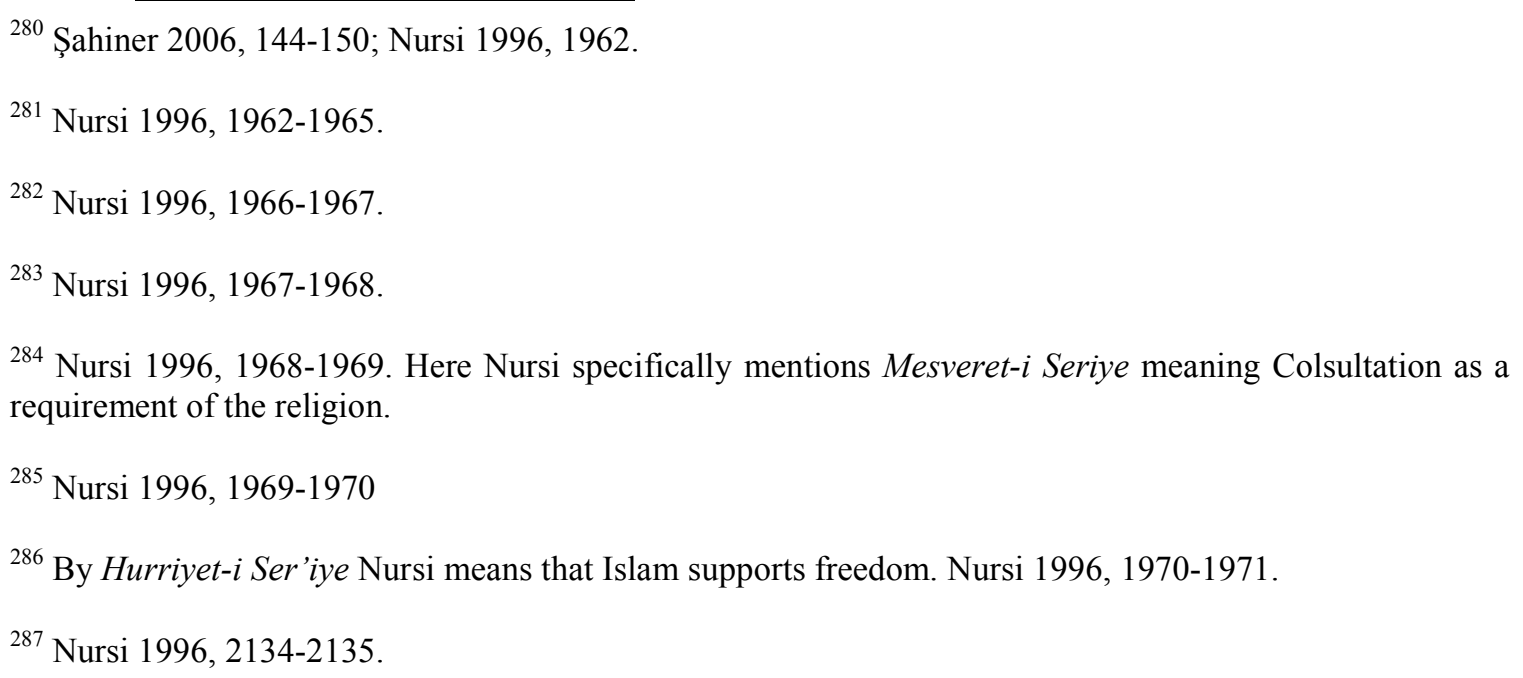


and was only able to return to Istanbul after the Bolshevik Revolution. Afterwards, he lived in Istanbul on and off until the end of 1922.

During his years in Istanbul, Nursi began to perceive at a deep level the almost unalterable changes in the religious character of society. As the Ottoman state declined in power, the educated elite preferred a western lifestyle to an Islamic one. Nursi warned his pupils about the impact of these changes in his publications and lectures. ${ }^{288} \mathrm{He}$ had a productive life in Istanbul. He published books and became an active member in social organizations. ${ }^{289}$ His actions were intended to promote an awareness and identification of the Islamic notion of all believers belonging to one Ummah.

He was not satisfied with the situation of the Muslim World. After WWI different independence movements emerged throughout Anatolia. Mustafa Kemal (Atatürk), who left Istanbul for Anatolia after the invasion of Izmir in May 1919, led the most prominent and ultimately the most successful independence movement. Under coercion by the invading powers, the office of the Sheikh ul Islam (the highest religious authority) of the Istanbul Government issued a fatwa (Islamic legal opinion) against Mustafa Kemal's independence movement in Anatolia. However, Said Nursi supported the independence movement, and issued a counter fatwa. ${ }^{290} \mathrm{He}$ lost his faith in the Istanbul government's ability to save the empire or promote the teachings of the religion. Apparantly, in these

\footnotetext{
${ }^{288}$ Said Nursi was displeased with the developments of his age. He was one of the earliest scholars to recognize the impact of globalization in transforming the world in to a village. His revivalist predecessors, like Imam Rabbani and Khalid al-Baghdadi, were aware of the changing environment during their lives; however, none of the transformations taking place in their era was as far-reaching as the effect of secularism and modernization.

${ }^{289}$ He published 19 books. Vahide 2005a, 15.

${ }^{290}$ Vahide 2005a, 16.
} 
days, he began to lose hope in politics as a method of serving the interests of religion. This feeling had been with him for some time but it only began to solidify at this time due to his age. ${ }^{291}$

From his own writings known as the Risale-i Nur collection, it is obvious that Nursi was comfortable with the idea of citizens becoming active in the political process; however, at the same time he retained a cautious attitude against the possible damages of politics. Nursi says that the purpose of writing Risale-i Nur is to serve God by teaching the necessity and benefits of faith (iman) ${ }^{292}$ In this respect, Risale-i Nur's main strength comes from the principle of sincerity (ikhlas or ihlas in Turkish) ${ }^{293}$ It does not pay attention to politics, but instead deals extensively with the issue of faith, purpose in life based on faith, and sincerity towards God in all one does. His intellectual focus was balanced between the promise of political power and the grave peril of possibly being overcome and corrupted by that power. When he finally realized the futility of pursuing positions in state institutions as a means to advance the cause of Islam, he ended his active political activity. He coined a famous saying: "I seek refuge in God from the Devil and Politics" ${ }^{294}$

\footnotetext{
${ }^{291}$ For more on Nursi's own account of transformation due to his age see Nursi 1996, 701-726.

${ }^{292}$ Nursi’s “20 $0^{\text {th }}$ Letter” specifically addresses Iman issue. For more Nursi 1996, 448.

293 "Twentieth Flash" is about sincerity (ikhlas). See Nursi 1996, 662.

${ }^{294}$ In its Arabic origin (written in Turkish as in Risale-i Nur) "Euzu billahi min es Seytan ves Siyaset" This saying is in one of Nursi's book called Sunuhat. It was written before 1920 and is not necessarily part of the core of the Risale-i Nur. Said Nursi also discussed the same issue in other places like his book Letters (Mektubat) which was written after 1926. For Sunuhat see Nursi 1996, 2050.
} 
The end of Nursi's active political life coincides with the fall of the Ottoman Empire. ${ }^{295}$ His change of attitude predates the Republican period and corresponds to the general failure of Islamists in gaining access to state power in a moral way. This was a direct result of the deterioration of the office of Sheikh al-Islam and the rise of the secularized bureaucracy which intensified an atomistic approach to the salvation of Muslims rather than an institutional one. In late 1922, Nursi accepted an invitation by the governmental body that represented the independence movement in Anatolia and went to Ankara. ${ }^{296}$ He attended a welcoming ceremony organized for him and gave a speech in the parliament. His visit to Ankara, where he met with the influential members of the parliament, increased his discontent with the materialism of the secular elite, and their blatant disregard for Islam as a legitimate point of reference in developing a national culture and identity. He tried to call the lawmakers to practice Islam by calling them to pray daily and perform other acts of worship for the sake of God. He even published a booklet about the importance of the five daily prayers. ${ }^{297}$

From the perspective of the secular elite in Ankara it must have been strange to listen to a scholar talking to them about the importance of belief in God and practicing religion while they themselves considered Islam to be the main cause of decline in the country. His experiences in Ankara might be considered as a peak of his transformation

\footnotetext{
295 Among other places, Nursi repeats his anti-political stance in "Lahikalar" (Addendum) which is a part of the Twentyseventh Letter (27. Mektub) published separately in Emirdag Lahikasi. Nursi 1996, 1797.

296 In his sympathetic account of Nursi's life, Akar argues that Nursi was invited to Ankara more than fifteen times some of which by Mustafa Kemal himself. See Akar 2008.

${ }^{297}$ Nursi stated this in different parts of his book. See Nursi 1996, 677 and 2138.
} 
into a rather apolitical position. ${ }^{298}$ Nursi readily admitted that his efforts did not pay. ${ }^{299}$ Although he was offered a government position Nursi rejected it and went back to Van, the city he left decades ago with a dream to study, teach, and live by the Quran. He decided to devote his life to the study of Quran one more time. He was perhaps willing to spend rest of his life in that cave. ${ }^{300}$ Nursi stayed in the Cave-Madrasa where he only devoted his life to his students and the study of Quran.

New Said Era (1920s - 1950):

The Ankara Parliament declared the Turkish republic in October 29, 1923. By then the Ankara government had established its authority as the sole legitimate representative of the Turkish people. The early years of the republic witnessed one of the most comprehensive reforms in Turkish history. On March 3, 1924, the parliament enacted a major law named Unification of Education Law (Tevhid-i Tedrisat Kanunu). The unification of education law brought all educational institutions under governmental control. This resulted in the closure of all religious madrasa schools throughout the

\footnotetext{
298 Akbulut-Kuru and Kuru 2008.

${ }^{299}$ Nursi argues that in Ankara he saw a group of people in disbelief in God. Therefore he tried to refute the ideas of positivists (Naturalists, Tabiiyyun) by publishing some booklets on Nature. However, he admits that it did not work (tesirini gostermedi in Turkish). For more see the Epistle on Naure (Tabiat Risalesi) in Nursi 1996, 677.

${ }^{300}$ Nursi 1996, 2139. The cave famously known as Horhor Medresesi was mostly used by Sufi tariqah teachers as an informal and later an underground school.
} 
country. On the same day, the office of Sheikh ul-Islam ${ }^{301}$ was closed and the Islamic caliphate was abolished. ${ }^{302}$

In 1925, the leading Kurdish groups, frustrated with the republican reforms in addition to not receiving the official promises of autonomy, rose up against the Ankara government. The groups led by the famous Kurdish religious figure, Sheikh Said. Sheikh Said asked for Said Nursi's support. Nursi presented a quasi-Ottomanist argument and argued that the Turkish children of the Ottoman Empire should be respected because they served the cause of Islam for centuries. His principle concern was to ensure that Muslims did not engage in fighting with other Muslims. ${ }^{303}$ Other Kurdish groups responded with dissatisfaction; they argued that the new government and its policies were anti-Islam and should not be tolerated. Nursi still declined to legitimize inner conflict.

Still, Sheikh Said and his followers began the uprising and declared a war against the Ankara government. The Sheikh Said Revolt, which is famous in Turkish as the "Seyh Said Isyani", led to a series of events that subsequently undermined the position of Islam in modern Turkish history. Sheikh Said lost the war but the government backlash was directed at all sectors of state and society. First the moderate government of Fethi Okyar-Celal Bayar was forced by Mustafa Kemal's closest associate, Colonel (Albay) Ismet, to resign. Ismet Pasa then formed a government and imposed martial law on the entire country. The Independence Tribunals (Istiklal Mahkemeleri) were established with

\footnotetext{
${ }^{301}$ Sheikh ul Islam as the utmost religious authority was the head of the Ministry of Sharia and Religious Foundations (Şeriye ve Evkaf Vekaleti) and oversaw the compatibility of the actions of the state with the Sharia constitution.

${ }^{302}$ Ahmad 1993, 80.

${ }^{303}$ For Nursi's conversation with Kurdish commanders who ask for his support, see Şahiner 2006, 278-282.
} 
the aim of officially indicting, prosecuting, and executing dissident voices. The Sheikh Said revolt gave the newly established government an opportunity to consolidate its power over state institutions and unite its forces against the dissident voices in order to forestall opposition to modernization reforms. ${ }^{304}$ The Independence Tribunals were instrumental in suppressing opposition through targeted, thorough, and widespread executions.

Because of the Sheikh Said rebellion, Said Nursi was accused of sedition, taken by government officials, and sent to exile to Western Anatolia. His arrest caused great unrest in the region. According to Abdulkadir Badilli, one of Nursi's Kurdish students, the people of the Eastern region were shocked upon learning that Nursi was apprehended and exiled by the state. Despite newly drawn borders, these people had relatives and friends in the other newly partitioned countries of the region. ${ }^{305}$ His exile lasted over 30 years until his death in $1960 .{ }^{306}$

The beginning of exile was the peak of the transformation of Nursi that began with his disillusionment in Istanbul. Nursi has always searched for new ways and methods to promote his ideals. He was never afraid of speaking truth to power. However, in his secluded years before the period of exile he was already beginning to become

${ }^{305}$ The locals offered him to take him away from the government officials and escape him to either Syria or Iran. Said rejected the offers and said that he had a mission to accomplish for this very Muslim society, children of a great nation that served to the religion of Islam. For more see Akar 2008, Sahiner 2006, 279280 and Nursi's biography in Nursi 1996.

${ }^{306}$ According to a newspaper article published by followers of Nursi, Nursi answered a question on why he lived all his life in prisons. To him it is a result of his disagreements with Mustafa Kemal. When Nursi criticized, Mustafa Kemal for the excessive nature of his reforms Mustafa Kemal reportedly responded in an angry tone "You will live rest of your life in exile!" The article is cited in Erdagi 2007, 190. This is one of the rare sources that confirms the open disaggrement between Mustafa Kemal and Nursi.
} 
softer. In his view, saving Islam meant not saving the Ottoman Empire but saving individual Muslims from straying from the guidance and spiritual nourishment offered by their religion. From this perspective, he was against any kind of rebellion or armed struggle against the authorities.

In the early republican era, the closure of traditional religious schools, sufi orders and bans on all kinds of religious education made Muslims more alienated from their environment. In this situation, Nursi pushed for seclusion and reconstruction of the faith from inside out rather from the periphery. Nursi was not an armchair theoretician or speculator; he experienced and perceived his future project as an isolated endeavor for sincere believers. ${ }^{307}$ On the other hand, he was not the only thinker to recognize the challenges and threats to his faith from changing environmental factors. There were influential figures who dealt with the same problems in the rest of the Middle East: Muhammad Abduh and Sayyid Qutb.

Comparing Nursi with Abduh and Qutb, Haddad says, "All three reformers focused on reinterpreting Islam for modern life. While Abduh struggles to modernize Islam and Qutb sought to Islamize modernity, Nursi's program at the end of his life sought to contain modernity, to devise a course of life that proves the sufficiency of Islam whatever its environment." ${ }^{308}$ His main aim was to establish an Islamic identity regardless of the environment. He called it "Haqiqah" (Truth). Haqiqah Islam gives

\footnotetext{
${ }^{307}$ Haddad 2003, 238.

${ }^{308}$ Haddad 2003, 240.
} 
primacy to the belief in God. ${ }^{309}$ Faith in God (Iman), as all Muslims believe in, is the first principle in Islamic thought. However, Nursi's interpretation of belief is distinct from Shariah and Tariqah-Islam in some major ways. ${ }^{310}$ First, contrary to Shariah Islam, Nursi does not think that there is only one level of belief. Those who have a strict interpretation of Islam overemphasize the differences between a believer and a disbeliever. For them if a person is a believer they automatically become superior to disbelievers, who are portrayed negatively. This stance acknowledges nominal Muslims as part of the ummah regardless of personal commitment to the ummah. One could be a Muslim but also aggressively secular and through a commitment to secularism they could undermine the needs of the ummah. Second, Nursi argues that belief is much more important than the spiritual pursuits such as spiritual pleasure, spiritual ecstasy, and keramat (supernatural actions). $"{ }^{311}$

In Nursi's Haqiqah interpretation, there are two levels of belief, belief by imitation (taklidi iman) and belief by exploration (tahkiki iman). ${ }^{312}$ Nursi argues that when tariqah members give excessive emphasis to spiritual pleasure limits the quality of the spiritual life of the entire community. It makes them weak and vulnerable to divisive internal and external factors. Among others, Nursi's "fifth letter" in his book Letters is devoted entirely to this issue. This work functions to explain why Nursi differs from

\footnotetext{
${ }^{309}$ For Nursi, Haqiqah is a new method: a marriage of hearts and minds of the people. For more see Vahide 2005a, 15-16.

${ }^{310}$ Vahide 2005a, 7.

${ }^{311}$ Nursi 1996, 355.

${ }^{312}$ Nursi 1996, 670.
} 
Tariqah Islam and justifies why the bond between man and God should be more important than personal spiritual pleasures. ${ }^{313}$

Often times, members of Tariqah escape from the negative impact of society and prefer to live in seclusion seeking spiritual peace. Nursi, on the other hand, argued that the dire condition of the humanity in general and Muslims in particular necessitates believers to sacrifice and struggle in order to reconnect human beings with their spiritual nature. Nursi argued that the loss of faith in God had become a major impediment in interpersonal relations. He stated that to believe in God individuals should rely on the power of God rather than their limited personal will. ${ }^{314}$ For Nursi, relying on God's power makes people more just while ego-centric life leads to selfishness and injustice. He was giving spiritual solutions to temporal and material problems.

For Nursi, a chaotic and brutal portrayal of the world is only possible if human beings de-sacralize the world. This is a product of the bifurcation of reality into secular and sacred realms. Nursi argues that the fundamental principle of this kind of a world is constant fight (jedal or cidal in Turkish). Jedal means conflict or chaos in a disorderly world. ${ }^{315} \mathrm{We}$ can argue that although they come from different perspectives those who escape from society for religious purposes and those who accept an atomized modern lifestyle are all divorced from the reality of God. They all fear that their environment will

\footnotetext{
${ }^{313}$ Nursi 1996, 6.

${ }^{314}$ Nursi 1996, 7.

${ }^{315}$ According to Nursi, the modern world "accepts 'power' as its point of reference in the life of society. It considers its aim to be 'self interest'. The principle of its life is 'conflict' (cidal)". Nursi 1996, 50. A similar version of this statement is also available, among others, in Said's Words book. For more see Nursi 1996, 183.
} 
have a negative impact on them. Usually both of these understandings lead to authoritarian state understandings, be it a leviathan or theocracy.

This is evident in Nursi's dissatisfaction with Abdulhamid II and early republican era policies. Said Nursi was unhappy with Abdulhamid II's authoritarian policies intended to improve the position of Islam. That is why he supported the secular Committee of Union and Progress (Ittihat ve Terakki Cemiyeti, ITC) because they promised freedom. ${ }^{316}$ However, after gaining power CUP continued authoritarian policies; eventually, its ideology gave birth to the Republican Peoples Party's single party regime which did not keep its promises. Eventually Nursi realized that structural reforms were insufficient to bring about change, so he returned to his roots. The atomistic approach as a societal project is the main difference between the revivalist and political Islamists; the revivalists give primacy to human beings one by one while for political Islamists it is the state apparatus that might help them to reach out to other human beings to shape and reform them. As Haddad states, "despite these similarities in experience" Nursi and his contemporaries "developed a radically different idea about the means of saving the Muslim ummah", 317

In Barla Nursi began to develop his project one person at a time. He was living in a very remote and underdeveloped part of the country. Western Turkey, with its

\footnotetext{
${ }^{316}$ Committee of Union and Progress was very popular not only within the bureaucracy but also among the religious scholars. The main commonality was their strong opposition to Abdulhamit II's Islamist but authoritarian regime, As Kara informs us, Tunali Hilmi Bey, major bureaucrat, often times published religious sermons embedded with Quranic verses and Muhamad's sayings which were outside of an ordinary bureaucrats expertise area. As Kara states, this was probably a result of ulema support to the bureaucracy in their fight against Abdulhamid. For more see Kara 1999, 66.

${ }^{317}$ Haddad 2003.
} 
somewhat secular residents have been quite distant from religion, although not entirely against it. This was a perfect opportunity for Nursi to achieve his goals from scratch. The elements of human agency according to Nursi are all related to religion as a faith rather than to worldly pursuits or the state. ${ }^{318}$ Focusing on scripture gave Nursi the means to reconstruct an Islamic identity that relied on the power of Allah.

His writings were less scholarly and more symbolic. Compared to his previous abstract works Nursi was becoming practical, trying to relate God to the practical aspect of people's lives. He reminded his students of Allah as the cause of all causes (Musebbibul Esbab), all-powerful (Kadir) and shaper of everything (Rabb). ${ }^{319}$ His idea was to call Muslims to the omnipotent, omnipresent, and omniscient God. Often his explanations were filled with stories that he gathered from the people of Barla. In stories recounted by local residents, they recognized Nursi through his continuous meditation (zikir) at night. His humble life, founded on strong religious practices, influenced the local residents and caused the people to come to him for advice and guidance. Barla was a small village whose residents were poor, just like Nursi. He may have intentionally begun his dawah activities in this environment because of the familiarity of it. The first piece Nursi wrote as part of his newly emerging magnum opus Risale was on resurrection and the life after death (Haşir Risalesi). It appears that Nursi directly targeted strengthening the faith of the believers, which was totally a contradictionto his previous political stance.

\footnotetext{
${ }^{318}$ Zubaida makes the distinction that religion as a faith involves elements related to the belief system rather than to religion as an ideology of the state. For more see Zubaida 2005.

${ }^{319}$ Nursi 1996, 76.
} 
The demographic characteristics of Nursi's followers changed as his message developed over time. He attracted a number of students (Risale-i Nur Talebesi) from all over the country who were interested in his teachings after having read Risale-i Nur. Nursi was able to author most of his major works in Barla, and, although he was in exile, he was attracting followers from the rest of the country who either read his short risale (letters), heard stories about him and were interested in meeting him, and other visitors who found his message relevant to their personal lives. The most important aspect of this newly forming movement was that it was connecting the people to the main textual sources of Islam. Traditionally Turkish society was socialized into Islam through the interpretive teachings of different tariqahs. Often these teachings contradicted the actual interpretation of the Quran by the prophet and the earliest Muslim community. However, in Barla there was neither established tariqah nor secular institutions to compete with Nursi's message.

His audience was, on the other hand, illiterate, at least in religious sciences. Until 1926, the official alphabet in Turkey was a slightly different form of Arabic that was called Ottoman. However, there was a problem: Nursi was not good at writing in Turkish. He learned to speak Turkish in his teenage years, but did not write. Nursi, therefore, sought the help of his expanding student body to record his ideas and print them in Turkish. ${ }^{320}$ He used to edit these works afterwards to check for errors and discrepancies. Student would reproduce these letters by hand because they did not have access to

\footnotetext{
${ }^{320}$ In some cases, Nursi dictated some of his books when he was in jail. His followers used to write what he said to the cigarette papers and then take these draft copies to the villages where the entire village reproduced the books late at night secretly. This and many other stories are told by the sympathizers of Nursi's followers in Erdagi 2007, 168.
} 
printing presses. His followers in their native towns and cities later secretly disseminated these works. ${ }^{321}$

After the Oneness of Allah, as the sole creator and 'owner' of the Day of Judgment, where all human beings will be resurrected, Nursi focused on issues like the role and normative example of Prophet Muhammad in Islam. His famous work on the importance of Prophet Muhammad is called Miracles of Muhammad (Mucizat-i Ahmediye). ${ }^{322}$ In $19^{\text {th }}$ Letter, Nursi commented on the importance of Prophet Muhammad and his tradition (Sunna) as the second pillar of religious knowledge. For him prophethood was the link between the divine and worldly. This was an identity construction based on the sources of Islam rather than outside references.

Rising dominance of Western values, therefore, was an important issue for Nursi. $\mathrm{He}$ "categorically rejected the concept of the West as normative or of its values as universal." ${ }^{323}$ For him, Muslim society had to be based on the sources of Islam itself. Nursi's ideas on the West and its degenerating impact on Turkish society are not different from that of Tariqah or Shariah Islam. Similarly, Erbakan was also critical of the West. Major difference in Nursi's ideas from these approaches and its impact on his followers has been the absence of a view based on constant conflict (or clash in Huntingtonian sense). ${ }^{324}$ His notion of self-reliance was instrumental to the process of identity

\footnotetext{
${ }^{321}$ This method became so widespread that it even became a branch of Nur movement later on who opposed the printing of the Risale in Latin alphabet. This group was called the scribers (Yazicilar). Yazicilar who is now a small group within the Nur community argued that copying and distributing Risale in Arabic alphabet also kept the people connected with the Arabic scripture.

${ }^{322}$ In a long section of the Mektubat chapter see Nursi 1996, 387-447.

${ }^{323}$ Haddad 2003, 242.

${ }^{324}$ Mardin 2005 [1991], 105.
} 
formation; and, his harsh criticism of western dominance pinpointed Nursi's account of the false dichotomies used within secular discourses and identity formation. ${ }^{325}$

His criticisms of western influence, however, were not essentialist because he did not view the West as a monolithic entity. He blended a detailed criticism of the anthropocentric tenets of modern thought with an appreciation of the progress and freedom of European society. ${ }^{326} \mathrm{He}$ had a twofold view of European culture: Christian Europe, which was based on the message of Jesus ${ }^{327}$ and the events of his life; and, secular materialism and positivism that is responsible for the general moral and spiritual corruption of modern societies, from notions of the state based on the security dilemma to the materialistic culture of modern capitalism. ${ }^{328}$

In Nursi's terms, this is the "decadent" nature of the European Civilization. ${ }^{329}$ This decadent nature is apparent to Muslims who have faith and can easily recognize human constructs that lead one to deviate from faith. Moreover, in the pre-Istanbul and Istanbul periods of his life, he was skeptical of learning from the West or apologetic approaches to secularism. Because modern Europe was alienated from its Christian origin through the influence of secularism, Nursi was apprehensive about modernizing Islam

\footnotetext{
${ }^{325}$ Haddad 2003.

${ }^{326}$ For somewhat critical analysis on Nursi's view on “two Europe's” see Brodeur 2005, 89-107,

${ }^{327}$ Nursi says "It shouldn't be misunderstood, Europe is two. One that follows sciences that serve justice and rights that are beneficial for the social life through the inspiration it has received from the true religion of Christianity." Nursi 1996, 643.

328 "[I criticize] the second Europe, corrupted through the darkness of the philosophy of Naturalism, that took the humanity to vice and misguidance by supposing the evils of civilization to be virtuous." Nursi 1996, 643. See also Aydin 2005.

${ }^{329}$ Aydin 2005, 157.
} 
along the same lines: the bifurcation of the secular and sacred spheres. Nursi did not think that there was any need to reform or modernize Islam. He only attempts to ground people in the long forgotten principles of Islam. To counter the negative, centrifugal effects of modernity Nursi felt "that it was necessary to fashion a cadre of Muslims whose lives are centered on the Quran."330

When Said Nursi emerged, the problem the Islamic world was encountering was not about the content of itiqad or its application. The problem was how these were perceived by the scholars and by the masses. In short, there was a need to articulate the values of Islam accessible to the modern mind. Supporters of Nursi claim that the movement is authentically traditionalist and is principally intended to rejuvenate the way Muslims think and practice. ${ }^{331}$ Disregarding the regional differences in its application, this issue involves the belief system (itiqad) and the jurisprudence (fiqh) of the Sunni Muslim world. In that regard, the Nur movement is a continuation of the mujaddidi/khalidi branch of the Naqshbandi movement.

For Nursi, belief required recognition of the oneness of God, His messengers, the Scriptures, angels, the day of Judgment, and predestination. Fiqh deals with how the belief system is applied in the social setting. In The Words, Nursi addresses the role of tradition, calling for a return to the original practice of the earliest Muslim community and identifying with the cumulative tradition that had developed throughout the Muslim world for centuries. In that regard, there is no fundamental difference between Nursi and

\footnotetext{
${ }^{330}$ Haddad 2003, 242.

${ }^{331}$ For more see Markham and Ozdemir 2005.
} 
Qutb. The major difference however lies in his ability to create a message embedded in the tradition, critical of the West but not conflict-prone.

\section{Gülen Movement}

The personality of Said Nursi and his message to his followers was deeply rooted in the modern Muslim experience, but at the same time connected to and invigorated by tradition. This is also evident in the Gülen movement. The Gülen movement is an offshoot of the Nur movement. It is inspired by the ideas of the prominent Turkish Islamic scholar M. Fethullah Gülen. He deserves attention because of his support for Turkish democracy within a more complex domestic and international setting than his predecessors do.

Gülen inspired the most prominent Islamic movement in contemporary Turkey. The movement inspired by his ideas has established over 200 private schools (elementary, secondary and high schools), over 100 university preparation courses, 3 national newspaper companies - one directly controlled by the movement- hundreds of radio stations, international TV broadcasting companies and banks. Outside of Turkey, the movement is active in over 100 countries operating schools and educational institutions which are estimated to number around $500 .{ }^{332}$ It has been highly successful in mobilizing people from Turkey to volunteer in these activities. Fethullah Gülen's success shows how inspirational his message is in the eyes of the volunteers, many of whom have never met with him.

${ }^{332}$ Different scholars give different numbers. See Agai 2003, 48. 
There are mainly two factors contributing to this process. First, Gülen has consistently educated students in a systematic way since the early days of his tenure as a preacher. From his writings and lectures we learn that he was a man of self-sacrifice in educating a young and loyal student body that would disseminate his message throughout the world. He was active in promoting projects for the benefit of his community and he was an effective organizer who tried to lead his studebts by example (temsil in Turkish). ${ }^{333}$ Gülen's immediate students who received their religious education directly from him accomplished many of the projects simply by following Gülen's role model. Many of the projects in different parts of the world have been undertaken directly or indirectly by the studebts inspired by Gülen's teachings. In order to reconstruct the 'true message of Islam,' Gülen chose loyal students to whom taught traditional Islamic sciences such as fiqh, Hadith, Arabic etc which required sacrifice. ${ }^{334}$ To accomplish his demanding teaching responsibilities, like his predecessor Said Nursi, Gülen has never married.

The second factor that made Gülen's ideas so widespread in the country and abroad was his ability to convey his message in a way that is appealing to a younger audience. Since the early days of his preaching years, as a long-term project, Gülen was able to influence the many young students to sacrifice for a bigger cause; the wellbeing of the society. His main argument was, which proved successful, that the sacrifices they

\footnotetext{
${ }^{333}$ For more on Gülen's method see Gülen 1998a and Gülen 1991.

${ }^{334}$ For more about the life styles of Gülen's students, his education method and curriculum see Canan 2007. Gülen, on the other hand, has been criticized by many for not following the marriage tradition of Muhammad who strongly suggested marriage to Muslims. The idea of late marriage or nor marrying at all is promoted in a book published by Gülen community. The title of the book is "famous singles." It has become a tradition in Gülen movement for his students to get married relatively later in their lives.
} 
were making were commensurate with thoseof the earliest Islamic communities of Islam. ${ }^{335}$ For example, in the eyes of Gülen's followers, prophet Muhammad's journey from Mecca to Medina to seek asylum and security to spread his message resembles the current case of Fethullah Gülen's movement. At the end of the Cold War, he urged his followers to go Central Asia to establish institutions to help the people of the region with education and development. Gülen argued that the sacred immigration (Hijra) is a duty on their shoulders to help their brethren in Central Asia who suffered "eighty years of communist oppression."

The frequent and strong references given to the early years of Prophet Muhammad's time have been the backbone of Gülen's message. He would frequently tell the story of Mus'ab bin Umayr, one of the earliest Muslims and close companions of Prophet Muhammad. Mus'ab left his wealthy family and immigrated to Medina to support the cause of Prophet Muhammad. He did not know much about the religion except for couple of verses he heard from the prophet. However, this young man was able to convince the entire city of Medina and make it the home of Prophet Muhammad. Many of Gülen's young followers took Musab as a nickname or named their male children after him. When the Cold War ended, Gülen was able to call upon "contemporary Mus'abs" to make the same sacrifice. The young generation of Gülen supporters embraced the idea of becoming agents of change for the message they got from Gülen's teachings. The dynamic relationship between the structural and spiritual factors led to the unprecedented

\footnotetext{
${ }^{335}$ While Gülen's immediate students are religious scholars with Islamic degrees, the followers who are inspired by Gülen and his students are mostly lay people with degrees other than Islamic studies.
} 
success of Gülen (including his immediate students) and increased its appeal among the younger generation.

There are three major eras in the life of Gülen (and his movement). First, the local life which lasted from his birth until 1960s when he left his hometown. Second, national appeal from 1960s to 1990s. Gülen began his activities in the 1960s and when he got to 1990s, his movement has become the most influential Islamic movement in the country. The third era from 1990s until present which corresponds to the internationalization of the movement. Beginning with 1990s Gülen 's students reached first to Central Asian Turkic Republics and as of today almost every country in the world has an interfaith dialogue or Turkish cultural center inspired by Gülen's ideas. His life story will be used in order to further explain these stages.

\section{Local Life: Formative Years (1940s-1960s)}

He was born in 1938 in eastern Turkey into a Turkish family. The region is known for its religious-nationalist culture which produced a handful of religious scholars and nationalist politicians. ${ }^{336}$ Gülen's family is originally from the city where Said Nursi was born (Ahlat town of Bitlis). ${ }^{337}$ The population in this region is a diverse blend of Turks, Kurds and Arabs. Like his predecessor Said Nursi, Fethullah Gülen's family is also descended from Prophet Muhammad. According to his own records, Gülen's birth caused a tension between his family and the early republican state officials. Right after the birth of Gülen, his father, Ramiz wanted to name him 'Muhammed Fethullah' after the prophet

\footnotetext{
${ }^{336}$ Hakan Yavuz describes the common culture as Dadas culture. Dadas people are known to be nationalist but not necessarily racist. See Yavuz 1999. However, within Dadas community Turkish nationalism still prevails strongly.

${ }^{337}$ Cities of Bitlis and neighbouring Siirt were, at the time, the religious centers of the Southeastern Turkey.
} 
Muhammad. However, the government official who was in charge of registering the birth certificates rejected this name due to its religious connotations.

It was secularism's heyday in Turkey. Angry with the registry officer, Gülen's father left without registering his son. After a while, Ramiz was elected to the village administration and established friendship with the military sergeant in the town. Three years after Gülen's birth, his father had another child. He took his military sergeant friend to the registry office with him. The Military sergeant ordered the officer to name the children the way Ramiz wanted. However, after the sergeant left, the registry officer named Fethullah without Muhammed and the other child Seyfullah (sword of God) instead of Sibghatullah (Paint of God) as the father originally wanted. That's why Gülen's official birthday is April 27, 1941, roughly 3 years later than the actual one. This event and how Gülen's father dealt with it are remarkable examples of how Muslims deal with the state and its policies. Instead of direct confrontation, they find a nonconfrontational way within the state bureaucracy. It still looks like, however, at the end of this process Muslims get only some part of what they want. This give and take and mutual accommodations make up the journey of Islam within the secular state.

In Gülen's ideals, the influence of his teacher, Alvar Imami, is obvious. ${ }^{338}$ As a Sufi master, Alvar Imami's message to Gülen was a classical Sufi principle that personal perfection is complete only if one serves to his/her God. ${ }^{339}$ In one of his famous poems, Alvar Imami shows how a Sufi should think and act contrary to whatever happens in a person's life.

\footnotetext{
${ }^{338}$ Erdogan 1995, 27-29.

${ }^{339}$ Ersöz 1991. Fethullah Gülen wrote the foreword of this book.
} 
Mevla Bizi Affede (May God forgive us)

Bayram ol Bayram Olur (Festivals become real celebration)

Curm-u Hatalar gide (May our sins go away)

Bayram ol Bayram Olur (Festivals become real celebration)

Gor ne guzel Iyd Olur (See how Festivals become real celebration)

For his entire life, Alvar Imami lived in the same village and educated students.

Therefore, in a more personal manner, he states that the most important time to cherish happiness would be the time when God forgives the sins. In Fethullah Gülen's views, however, a more social devotion by serving God via helping people without thinking or expecting a return is praised. The social altruism that is based on his contacts with sufis in his early life marks a one step ahead in Sufism that becomes the main tenets of his life to come. In one of his recent writings Gülen mentions importance of people "who will feel the [pain] in their hearts about an oppressed child in so,e forgotten part of the world." ${ }^{340}$ Gülen's preference of social action or sacrifice to Sufi seclusion is probably due to his early acquaintance with Said Nursi's ideas.

For the first time, Gülen met with the members of the Nur community in 1957. The lecture of one of Nursi's student inspired Gülen to pursue dawah method of Nursi. ${ }^{341}$ He saw the ideal of self-sacrifice of the companions of prophet Muhammad (Sahaba) in Said Nursi and his students. The companions of prophet Muhammad are important role models for Gülen ${ }^{342}$ because they emerged at a time when Arabian society was in a state of chaos. Yet, the companions of prophet Muhammad constantly struggled to fulfill the

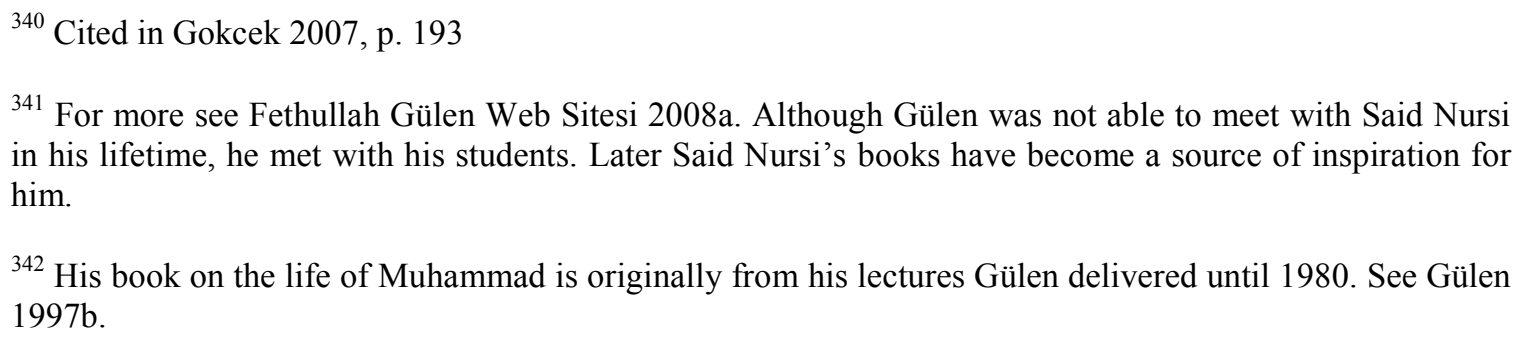
him.

${ }^{342}$ His book on the life of Muhammad is originally from his lectures Gülen delivered until 1980. See Gülen $1997 b$. 
message brought to them by prophet Muhammad. An objective assessment of their lives and accomplishments served to inspire Gülen and his students that the effort (jihad) they made on behalf of Islam would be successful, regardless of structural constraints. ${ }^{343}$

Gülen's argument was simple. Outside social and economic pressure along with inner conflicts created by a wholly materialistic worldview create many problems in the lives of modern people. Gülen argued that modern life creates internal tensions within people between the material circumstances and the belief systems of faith. In this era, the role model for ordinary people cannot be saintly, but must come from the same environment. The example Gülen wanted to show to people was of ordinary Muslims who could live in the world and be successful and happy, but not be dominated, affectively, by the material aspects of modern life. They serve as examples of how a religious life uniquely leads to personal happiness and inner peace. ${ }^{344}$

From the beginning, contrary to many Islamic movements in Turkey, Gülen was against a "saint-centered" religious approach. Many tariqahs, religious orders and religious communities establish their movements around the stories of saints and other charismatic figures who claim to have extraordinary spiritual qualities. Their followers believe that these self-proclaimed saints can see the future or cure illnesses. ${ }^{345}$ In Gülen's view, this kind of elitist religious understanding alienates the masses from the message of God and instead elevates certain Sufi mystics above even the prophet, because they have

\footnotetext{
${ }^{343}$ The reconstruction of the idea of jihad as a personal struggle rather than a wholly war has been dealt extensively in Gülen 1997a, 186-219.

${ }^{344}$ Kuru calls this a middle way. For more see Kuru 2003.

${ }^{345}$ Latif Erdogan's interview with Gülen has highly detailed and first hand information on Gülen's methods and critique of saint-centered Islam. For more see Erdogan 1995.
} 
authoritative status among the uneducated population. Therefore, for Gülen any Islamic movement for reform must renew the faith based on prophetic tradition's semiindividualistic approach where each individual has the right and authority to claim responsibility rather than deferring it to saints who have supernatural qualities.

In line with this reasoning, Richard Bulliet explains the importance of companions of prophet Muhammad as individual agents in Islam. Contrary to the established reading of Islamic history in the Muslim world and in Orientalist scholarship, Bulliet argues that we need to have a view from the edge, rather than the center, to be able to grasp the development of an Islamic society in the ages of turmoil and progress. Bulliet's view from the edge is important because it directs scholarship to the peripheries of society to understand the religious transformation in Turkey by movements that had quietly gained momentum. As Bulliet states, "the view from the edge is not that from a geographical (or political) periphery. The edge in Islamic history exists wherever people make the decision to ... rededicating themselves to Islam as the touchstone of their social identity, or recasting their Muslim identities in a modern urban context." ${ }^{346}$

The view from the edge recognizes that edge is the source that creates the center: it is a centripetal force. The centrifugal paradigms that prevail in scholarship on Islamic movements in general limit them from recognizing the fact that it is the periphery that is ultimately creating the center. Unfortunately, the centripetal forces are the least studied aspect of the Islamic movements in the world, and this applies equally to the Gülen movement. Bulliet argues that:

${ }^{346}$ Bulliet 1994, 9. 
Muhammad and virtually all of the companions were Arabs who shared a common language, culture etc. These companions, particularly after the death of Muhammad became revered as repositories of knowledge about the prophet [and his tradition]. ${ }^{347}$

Bulliet's reading is accurate and just as relevant to the contemporary Muslim world as it was to the earliest period. In an age full of uncertainties and confusion the interpretation of the Qur'an and traditions of prophet Muhammad is plagued by reactionary and anachronistic interpretations by Islamic movements. Particularly noteworthy was the inability or unwillingness of the Islamic caliphate to institutionalize alternative means of giving authoritative Islamic answers to specifically modern problems. In the absence of an Islamic caliphate, and both a real and symbolic institution capable of uniting Muslims, the history of the earliest companions provides guidance to the contemporary Muslims who experience the similar problems. ${ }^{348}$

This issue is particularly relevant to the Turkish Islamic case. The republican era in Turkey imposed secularization on the nation as a necessary means towards modernization. However, it was unable to generate a nationalist mythology beyond the image of Kemal Ataturk. Moreover, while the secular authorities promised prosperity, peace, and security as a corollary of modernization, they eventually failed to improve the lives of the masses. In addition, the rampant corruption and self-indulgence of some of the bureaucratic elite undermined their credibility. Gülen was able to appeal to early Islamic history as an alternative Turkish-Muslim history. The example of the prophet and his followers were contrasted favorably to the degenerate elite in Istanbul and Ankara.

\footnotetext{
${ }^{347}$ Bulliet 1994.

${ }^{348}$ The prophetic tradition is important because it represents a body of knowledge that can be accessed by Muslims at any time in order to renew the Islamic belief system in times of turmoil and confusion.
} 
Since the early days of his life, Gülen's view on Islamic renewal has been based on the implementation of the prophetic tradition "in a modern urban context". Fethullah Gülen's position has been consistent with other Islamic movements in that he legitimizes his ideas as a return to tradition. The most important aspect of his interpretation of the prophetic tradition included the idea of teaching and conveying the message to the coming generations via a small group of loyal followings, similar to the Ashab-i Suffa of Medina. ${ }^{349}$ According to Muhammad Hamidullah, after prophet Muhammad migrated to Medina the southern part of the mosque (the first religious institution) in Quba was given to a group of students who spent all their days studying religion directly from the prophet. ${ }^{350}$ These students are called People of Suffa (Ashab-i Suffa), and numbered around 400. Their close connection with the Prophet (who also lived in the Mosque) is a source of information on the teachings and life of the prophet. This led to the centrality of hadith literature transmitted by the companions. There were major companions of the Prophet who lived with the Suffa group: Mus'ab ibn 'Umayr, 'Abdullah b. Mas'ud and Abu Hurayra ${ }^{351}$, who narrated by far the most hadith from the prophet. The contributions of these close companions of prophet Muhammad became the source of Islamic tradition." 352

\section{Nationwide Opening: Reaching out to a Bigger Audience (1960s - 1990s)}

\footnotetext{
${ }^{349}$ Some recent works emphasize the similarity between both methods. See Atay 2007.

${ }^{350}$ Hamidullah 1990, 768.

${ }^{351}$ Abu Hurayra's position in the Islamic tradition is contested both by Shi'a and some other Sunni scholarship. For example, the number of the hadith he narrated is questioned by many although he is well respected in the Turkish Sunni community and by Fethullah Gülen himself.

${ }^{352}$ Bulliet also mentions this issue without giving reference to any specific companion. Bulliet 1994, 16
} 
Fethullah Gülen established his Ashab-i Suffa first in Edirne, a secular border town in North-Western Turkey. It was the first city he officially worked in after he left his hometown. In 1964, right after he began his job as Imam in Dar al-Hadith mosque he prepared a room for a group of students in order to teach them Islamic sciences. ${ }^{353} \mathrm{He}$ was a devoted teacher to his students. His own accounts present this method as a sacrifice on his part for a better future of the students. He argues that he sacrificed for their intellectual and spiritual nourishment, so that, when they were properly trained and ready to enter the world, they would be willing to make sacrifices of their own for the society. ${ }^{354}$ Later on, Gülen's study circle took a more established form where initial 10 students began to study traditional Islamic sciences. ${ }^{355}$

After Fethullah Gülen finished his military service, he began to give lectures about Mawlana Jalal al Din Rumi. While secular scholars portrayed Rumi as a humanist and pantheist rather than an orthodox Sunni scholar and mystic, Gülen delivered lectures on Rumi's dedication to the Hadith tradition. ${ }^{356}$ The respect Gülen showed for the religious authenticity of Rumi was an attempt on his part to rescue Rumi's religious character from secular readings of Sufism. Rumi is popularly known as a poet and mystic, yet, for Gülen, Rumi's entire system of thought and action was based on the

\footnotetext{
${ }^{353}$ In his memoirs, he mentions how it was difficult to find students in Edirne which was weak in terms of God-consciousness. Erdogan 1995, 84-85.

${ }^{354}$ Fethullah Gülen Web Sitesi $2008 b$.

${ }^{355}$ A close student of Gülen, Ahmet Kurucan, mentions the long list of books Gülen used in his curriculum. For more see Kurucan 1997, 14.

${ }^{356}$ In his biography, he states that because he spoke Rumi's poems and ideas first in their original Persian and then translated them into Turkish it had more effect on the audience. For more see, Fethullah Gülen Web Sitesi 2008b.
} 
Quran and Sunna of prophet Muhammad. By emphasizing Rumi's attachment to the normative practice of prophet Muhammad, Gülen was able to move the discussion from literary concerns with the style of Rumi's verse to the affective influences on Rumi. The primary influence on Rumi was the traditional material and the general Quranic discourse on God, His messengers, the unseen world, the various examples used in the Quran about communities that disobeyed God. The thought of someone like Rumi, who has been romanticized in secular circles as a carrier of spiritual teachings, divorced from the sources of Islam of course, was actually part of a revivalist movement in thirteenth century Anatolia. ${ }^{357}$

In 1966, Fethullah Gülen was assigned to work in Izmir. Izmir had always been known as a secular region, dismissive towards religion. An Aegean Sea port city near Greece, Izmir presented some very profound challenges for Gülen. Ordinary people in the Aegean Sea region had previously been in contact with Said Nursi due to his years in exile in the region as well as the popularity of his treatises. However, they were informed about Nursi's message only to the extent of intellectual assent and agreement. They had not yet come to understand that Nursi was doing more than just writing in order to spread ideas about spirituality, outside the context of duty and sacrifice. Nursi wanted to train and create agents of Islamic revival in the face of the onslaught of secularism. He laid the intellectual foundations for such a project. When Fethullah Gülen arrived in Izmir, he worked to transform the intellectual assent with the ideas of Nursi into obedience to

\footnotetext{
357 Thirty years after Gülen gave his first lecture on Rumi, his sympathizers named their first major institution in the USA after Rumi. Rumi Forum is a leading pro-Gülen institution involved in interfaith dialogue activities.
} 
tradition and social activism. For the coming thirty years, secular Izmir would become the backbone of the Islamic movement of Gülen.

The 1960s corresponded to the post- Nursi era for the Nur community. After his death in 1960, Nursi's devout followers formed various communities under the leadership of his immediate students. This group was known as "older brothers" (Agabeyler). They were de facto leaders of the religious community and legacy of Nursi, though the absence of a charismatic leader made their efforts difficult. They tried to preserve the teachings of Nursi by strictly following his representation of tradition. There was a vacuum of leadership among the followers and student of Nursi which would come to be filled by Fethullah Gülen. In addition, just as he was able to re-represent the teachings of Rumi as an extension of orthodox Islam, Gülen emphasized that the writings of Nursi were less doctrinal treatises and more a call to action by believing Muslims.

The Nur community, however, would later alienate Gülen by attempting to enter into the political arena in an alliance with the centrist Justice Party (Adalet Partisi, AP). Gülen repudiated this attempt to politicize the movement, distanced himself from the members that were taking the movement in this direction and renewed his focus on the prophetic tradition and educational activity. He was in an advantageous position to carry on the message and work of Said Nursi because he was well trained in the Islamic sciences: jurisprudence, Quranic exegesis, and hadith. Most other leaders within the Nur movement were dependent on the writings of Nursi for their Islamic education. Like Nursi, Gülen was fluent in Arabic and Persian, at least in terms of reading and interpreting the texts. His language skills gave him access to the sources of religious scholarship in rest of the Islamic World. No other Nur student was fluent in as many 
Islamic languages. This diminished their appeal among the ordinary members of the Nur community. This is reflected in the quality of their scholarship and its application.

Fethullah Gülen dedicated his time to training his students as agents of change. He felt as though this was the best way of effecting change in Turkey and the Muslim world. This method exponentially increased his influence in the instruction of Islam. He would focus on the development of a few of his brightest students, preparing a curriculum specifically for them. Then they would mature intellectually and work under his supervision in the development of the next group of students. From the time he distanced himself from the mainstream followers of Nursi over their political activity he established his movement on two pillars: religious education at a high level and the development of a capable student body through direct instruction. ${ }^{358}$

In the late 1960s and early 1970s, Fethullah Gülen was still trying to find his place as an Islamic leader. He was not able to bring the followers of Nursi under his direction easily. Gülen brought unique skills to the Nur movement. Gülen's leadership made his students more efficient and effective. He first began to promote his ideas in local cafes where people spent their leisure time playing cards, drinking tea, smoking and

\footnotetext{
${ }^{358}$ In June 1997 during a research trip in Amman, Jordan, I met with some students of Gülen. According to what they told me, Hocaefendi (Gülen's nickname among his followers) was sick and he could not continue teaching series for a while. Therefore, Gülen sent them to Jordan to practice Arabic to benefit better from the courses. The students were M.A. and Ph.D. level theology students led by Fethullah Gülen's long time friends. Initially, method of educating students was dismissed by other Muslim groups in general and the National View Movement in particular, but after 40 years Gülen has managed to establish an educational empire that is continuing to expand globally. Fethullah Gülen also benefits from having a loyal following that is dedicated to the cause of Islam and is willing to sacrifice their own ambitions, ego (nafs), for the sake of ideals inculcated into them by Gülen. After all, he took a detailed interest in their training and inspired them to do the same with their students. In this respect, he has revived and popularized one of the distinct features of the teacher-pupil relationship in Islam, particularly in Sufism. Sufi masters demanded absolute obedience from their pupils because they had already walked the path and were able to guide their disciples.
} 
chatting late into the night. In his memoirs, Gülen says that his aim was to go to reach out to people who did not regularly attend the mosque. ${ }^{359} \mathrm{He}$ wanted to reach more people and inspire them to be more interested and educated in religion. His followers rented large pubs or concert halls during the weekends and Gülen lectured on the benefits of creationism over Darwinism and gathered "thousands of people from all parts of the society." ${ }^{360}$ No other religious community, including the Nur community, had organized anything like this.

In the late 1970s, however, there was turmoil in Turkey. Divisive fights among college students and government officials brought parliament to a halt. Members were unable to elect a President for over 100 sessions. On September 12, 1980, the military overthrew the government and declared martial law throughout the country. Due to his prominent religious position in the Aegean region, Gülen was among those suspected by the government of political radicalism. For the next 6 years, he went underground in hiding from the military scrutiny.

Some scholars argue that the repression of Islamists in general and Gülen in particular, produced a diaspora mentality and group mythology that came to dominate the Islamist discourse in Turkey. ${ }^{361}$ According to Yasin Aktay the Turkish diaspora is not related to demographics and population movement, but rather a discursive one where

\footnotetext{
${ }^{359}$ Coffee House visits began in 1969. Erdogan 1995, 94-98.

${ }^{360}$ Gülen states that this was his first public conference in Izmir where he was able to reach people outside of mosque circle. Fethullah Gülen Web Sitesi 2008b.

${ }^{361}$ Aktay 2003, 132.
} 
people felt "being stranger and pariahs" in their own homelands. ${ }^{362}$ He analyzed the ideas and lives of prominent contemporary Islamic figures like Mehmet Akif Ersoy (the author of the Turkish national anthem), Mustafa Sabri Efendi (the last shaikh ul Islam of the Ottoman Empire), Necip Fazil Kisakurek (a prominent Islamist poet), and Elmalili Hamdi Yazir (a well known religious scholar who authored the first Turkish interpretation of Qur'an).

Aktay argues that this feeling of inhabiting a discursive diaspora resulted in a search for stability in the hearts and minds of the Islamist intellectuals, notably Fethullah Gülen. This search for stability resulted in a search for legitimization at the state level which created a pro-state, somewhat nationalistic stance within Islamic movements. Fethullah Gülen was patriotic; according to Yavuz, the frontier conditions of his hometown (Dadas culture) caused him to support the state ${ }^{363}$ because of the fact that state apparatus provides security for its citizens, a strategy that has long been followed by the Naksibendi order as well.. However, Yavuz's Dadas culture thesis is limited by its implicit structural bias. Nationalist sentiments stemming from the Dadas culture might have affected Gülen's ideas but they were at most secondary to his universalistic Islamic message. Gülen's ideas where nationalism plays a secondary role to religion is more similar to Neo-Ottomanism than any other ideology. Nationalist Dadas culture is often times associated with intolerant reactions towards pluralism within the society,

\footnotetext{
${ }^{362}$ This is originally a statement from a poem of Necip Fazil Kisakurek, prominent Islamist poet, who is respected by many Muslims including the leadership of Justice and Development Party government. The poem is cited in Aktay 2003, 132.

363 Yavuz 1999, 594.
} 
particularly against Kurds, Communists and non-Muslims while Gülen tried to preserve a tolerant stance. $^{364}$

Gülen, on the other hand, did not search for stability, in the Hobbesian sense, but the realization of renewal (Tajdid), purifying society from social problems. Tajdid recognizes the fact that the values of a society degenerate over time and human beings lose their connection with God. The presence of this decay creates a sense of alienation from the ideal Islamic imaginary. Therefore, rather than focusing on state apparatus, Gülen, as his predecessor Nursi, aimed to continue their renewalist tradition which required focusing on the self than the other. In that regard, Gülen shares the same ideas with many of his Ottomanist predecessors who initiated a self-critique process.

Gülen, however, differs from many of his predecessors in his pragmatism in utilizing new methods. His community used every means to reach out mainly to the young generation and try to create its own "golden generation." Gülen mainly, if not solely, focused on the importance of education more than institutional reforms preferred by his predecessors. The term "Golden Generation" (Altin Nesil) refers to the ideal posterity in the mind of Fethullah Gülen which was formulated during lectures and writings since 1970s. From these writings and lectures, he continuously described an ideal generation which, he argued, will "save us spiritually." 365 Referring to Plato's Republic, Al Farabi's The Virtuous City (Al Madina al Fadila), and the City of the Sun of Tommaso Campanella, Gülen argued that his ideal generation is not a theoretical

\footnotetext{
364 In Gülen's hometown, one missionary has been murdered by local nationalists who argued that missionary activities were threatening Islam. Gülen, of course, has never resorted to violence nor approved.

${ }^{365}$ Gülen 1977.
} 
construct like these scholars but an ideal based on the practices of the "Rose Age" (Gül Devri), meaning the age of prophet Muhammad. ${ }^{366}$

In one of this lectures he gave before the 1980 coup, Fethullah Gülen mentions three main qualities of his ideal generation. ${ }^{367}$ First is Love (Muhabbet). Gülen argues that members of the golden generation love both their friends and enemies. In mainstream identity formation literature that is influenced by social identity theories, a sense of belonging or personal identity is dependent upon the construction of an anti-self, an 'other'. Gülen was aware of this tendency to articulate personal identity in opposition to others. In addition, he wanted to eliminate this kind of behavior among his followers. Therefore, he used the example of the companions of the prophet as well as the messenger himself to teach the art of love. Love, or the ability to look towards others sympathetically, stops the ego from using the external image to produce ideas about the self.

The second quality of the golden generation is [positive] action (hamle). Fethullah Gülen says that a person should first act to conquer his own soul, then propagate the message to other members of society. This is a social aspect of the golden generation. In his teachings, Gülen mention Jesus as an example of a prophet who was constantly purifying himself. Love was the main component of Jesus's message, one idealized by

\footnotetext{
${ }^{366}$ Gül Devri involves a literary symbolism popular among Islamists in Turkey. Out of respect, Muslim literary artists refrained from using Muhammad's name openly. Therefore, in their works Muhammad has been referred as "Gül" (Rose) which is the favorite flower of the bird nightingale (Bülbül). Poets considered themselves as the bird Bülbül which constantly sang love songs in the absence of the beloved "Gül." In one of his poems Mehmet Akif, the author of Turkish national anthem and proponent of Ottomanist thought, said, "Had I seen the rose age, I would be its nightingale" (Gul devrini gorseydim, o devrin bulbulu olurdum.)

${ }^{367}$ Gülen 1977.
} 
Gülen. Jesus looked at people with love and did not understand his own identity against a negative appreciation of them. Gülen always gives references to the mission of Jesus, and how the golden generation is the last bearer of this message. The appreciation of the Nur community for Jesus, something promoted by Nursi, has given their movement an aspect of spiritual humility.

The third quality of the golden generation was self-criticism (murakabe). Considering the date of this lecture (1977) when conflicting sides of a polarized Turkish society were attacking one another, Gülen must have been calling upon people to be mindful of how they behave towards one another, and before acting, to be mindful of how they speak to one another, and before speaking, to be mindful of how they think about others. It is on the level of thought that the hatred of Turks for one another is formulated. They act out these generic identities upon one another. Again one can look to Jesus, the prophet Muhammad, or his companions as ideals of people who were selfcritical, not externalizing their judgmental faculties. ${ }^{368}$

After the 1980 coup, the military government shut down all student dormitories run by the Muslim communities. These dormitories were mostly non-profit organizations (vakif), so it was easy for the military administration to takeover these institutions and reallocate their resources. At this point Gülen's community was operating some student dormitories for high school and college students. To keep the institutions safe from

${ }^{368}$ Gülen shared similar ideas in his first religious lecture he gave in Yeni Cami of Istanbul on August 26, 1977. The topic of the lecture was a call for Muslims to criticize themselves before blaming others. 
government takeover, Gülen's followers switched all the non-profit institutions to forprofit private schools. ${ }^{369}$

The first known institution of the Gülen community would be Yamanlar Private High School located in Izmir where Gülen preached for years. It was established in 1982. Other major institutions which are now leading national private high schools are Fatih College - Istanbul (1982), Samanyolu College -Ankara (1983). Later, establishing private high schools became one of the main methods of the Gülen community. There are an estimated 300 private schools in Turkey. Due to the university entrance system, college preparation institutions are also popular in Turkey. The Gülen community has around hundreds of these institutions which serves as another venue to build relationships with students.

These schools and institutions are now associated with high level science education in Turkey. The winners of national and international science olympiads are often from these schools. Why is science so important for Gülen? The answer goes back to Said Nursi, who saw the problems of the Muslim world as related to two issues; rejection of religion in scientific education and rejection of sciences in the religious life. Fethullah Gülen, by opening these schools, brought scientific education back into the lives of Muslims. In addition, in late 1979 Gülen's community began to publish Sizinti, a monthly popular magazine that focused on issues important to the Gülen community: proving Darwinism false and supporting creationism. The importance of creationism and

\footnotetext{
369 Traditionally private schools were businesses of elite secular Turks in big cities while student dormitories and Qur'anic schools were traditional Muslim organizations.
} 
the existence of God were necessary because of the rise of communism and scientific atheism.

In the media sector the most important accomplishment is the establishment of the Zaman newspaper in 1986, right when Fethullah Gülen's underground life ended. Zaman, which is currently the bestselling newspaper in Turkey, was established together with different Muslims groups, and later solely controlled by the Gülen community. ${ }^{370}$ Until the 1990s Gülen movement's activities were given little media coverage. Due to its local and decentralized structure the movement was never adequately represented in the media, academia and in policy circles.

\section{End of the Cold War: Internationalisation of the Movement: (1990s- present)}

With the end of the Cold War came the internationalization of the Gülen community. It was the ability of the movement to forsee the transformation of the world politics and find the opportunity to develop a new phase in their dawah method. ${ }^{371}$ These were the results of Gülen's speeches beginning in late 1980s when he began to preach about the importance of re-connecting with the people of Central Asia. He knew that once his followers saw what the material and spiritual condition of the Central Asian peoples, after

\footnotetext{
${ }^{370}$ The establishment and purchasing of the Zaman newspaper show the rising economic power of Gülen community and its loosely connected members.

${ }^{371}$ In one of his recent books, Ali Bulac explains the very first activities of Gülen movement. Bulac says that on January 11, 1990 almost two months after the collapse of the Berlin Wall 11 volunteers from Gülen movement went to Tblisi, Georgia. This was the very first step. Three months after that in May 28, 1990 another group of volunteers (this time 37 businessmen) went to a long trip to visit Georgia, Azarbaijan, Turkmenistan, Kazakstan, Kyrgysystan and Tajikistan. However, Bulac, a major Muslim thinker in Turkey, seems critical of Gülen schools. He does not find these activities Islamic enough. For more see Bulac 2007, 281-305.
} 
coercive state secularism, they would be inspired in their activism and inspiring in their call to Islam. For Gülen this was a paypack to their ancestors. ${ }^{372}$.

Opening schools in Central Asia had a transformative effect on the movement. First, it made the community dynamic in terms of its cultural horizons and educational capacity. Students from the Gülen schools began graduating from college and working in these new institutions early 1990s. Second, this Central Asian expansion was the first step in internationalization of the community, transcending national borders and state allegiances.

Initial support came from the newly elected President Turgut Özal. Özal saw the Gülen movement as a fulfillment of his vision. Originally a member of the Naqshbandi movement, Özal was able to rise to the highest ranking position in the country due to his ability to maneuver within bureaucratic circles. Özal was the person who began the liberalization of the economy and opening the country to the world market. His policy program intersected with the activities of the Gülen community, and Özal always helped the community during his short tenure in presidential office. ${ }^{373}$

In Central Asia, the Gülen community opened schools similar to the ones in Turkey. ${ }^{374}$ From the early writings and speeches of Gülen it is not clear what the

\footnotetext{
372 The influence of Naqshbandi movements, was the agent for the Islamization of the Asia Minor. Some scholars argue that the Islamization of Anatolia was due to missionary activities as well as voluntary conversion on the part of the invading Turkish people inspired mainly by Naqshbandism coming from Central Asia. Koprulu and Lutfi Barkan argue that the mass movement of Turks from Central Asia inundated Anatolia with invading Turkish tribes, and that this influx of people is responsible for the Islamization of AnatoliaBarkan 1942; Koprulu 1992. Koprulu's book was originally published in the early 1920 's before the establishment of the Turkish republic. The Original text is written in Ottoman Turkish (with Arabic letters).

${ }^{373}$ He unexpectedly passed away in 1993.

${ }^{374}$ Demir, Cengiz and Akkok 2000.
} 
movement exactly knew about the region. Considering the enmity between Turkey and the USSR during the Cold War there had been contact between Turkish people and their Central Asian brethren. Fethullah Gülen's post-Cold War speeches were intended to create a sentimental connection between his followers and the newly independent states. For example, he mentioned that there was a place named Mengucistan that needed help. This place only existed in the region during the pre-Ottoman period. Aside from the material weakness of the arguments, Gülen had spiritual authority behind his claims. He was essentially asking his followers to sacrifice for a greater cause, a greater effort, a Jihad. His definition of jihad is based on spiritual principles of service to the community. It is struggle between the self and the soul through humanitarian work. Gülen's specialty was education. This spiritual connection did not require material evidence and the members of the Gülen movement began to spread their message.

For many in Turkey this was exporting "Turkish Model" to a region which was under Iranian and Wahhabi influence. In policy circles, especially with U.S. support, the Turkish model of a secular state with a moderate pro-western Islam was the most highly regarded alternative. The international support for the Turkish Model also contributed to the expansion of the Gülen community in the region without any impediment until suspicion and resistance replaced the "cautious acquiescence of Russia" and some other Central Asian states. ${ }^{375}$ At times the activities of the movement was considered too proAmerican, and schools run by Gülen community both in Russia and Uzbekistan were closed by the state in late $2000 .^{376}$

\footnotetext{
${ }^{375}$ Mohiaddin Mesbahi explains the limits of the "Turkish Model" in the region. Mesbahi 1994, 217-224.

${ }^{376}$ The school closures in Russia were temporary while in Uzbekistan Gülen community's schools closed permanently.
} 
Gülen welcomed the image of himself and his movement as moderate representatives of Turkish Islam. Any analysis that views the expansion of the Gülen community's activities as a regional pan-Turkish or pan-Islamist project would be valid in its understanding of certain particulars of the movement's history and organization but would altogether misunderstand the inner dynamics of the movement. Their positions visà-vis the major powers were not dependent on fear of punishment or hope for rewards because they were acting on ideas which were deeply grounded in the teachings of Islam. Gülen often times stated that fear, hope, and love should only be directed towards God, because only God is worthy of such attention. ${ }^{377}$

Gülen movement's activities soon became so popular and well recognized that they had to justify their activity, on secular grounds, to the ruling regime. He met with politicians, party leaders and eventually with the Prime Minister Tansu Ciller ${ }^{378}$ on November 11, 1994. Gülen was already known throughout society but this was the first time his community was given recognition on the governmental level. ${ }^{379}$ In 1994, Gülen's close associates founded the Foundation for Journalists and Writers (Gazeteciler ve Yazarlar Vakfi) ${ }^{380}$ which became the venue for his (interfaith) dialogue activities. ${ }^{381}$

\footnotetext{
${ }^{377}$ For more, see fear (havf), hope (reca) and love (ask) articles in Gülen 1994.

${ }^{378}$ Ciller is Turkey's first female Prime Minister elected from center right TPP ticket.

${ }^{379}$ Fethullah Gülen began to give interviews to leading newspapers. For example, Sabah and Hurriyet published interviews with Gülen same day (January 23, 1995) due to his rising popularity.

${ }^{380}$ In the opening ceremony, Fethullah Gülen stated that Turkish democracy is so ingrained in the masses that in the future there could be no retreat from it. For more see Sevindi 2008. In his works Gülen deals with this issue in depth. Giving a moral perspective based on ihsan principle, he argued that a sacrifice of ethical values for temporal gains results in failure both in the world and in the hereafter. Those who inherit the world, he says, should not try to dominate it, but try to establish justice and wellbeing in it. For Gülen's ideas on democracy, see Gülen 1998b.
} 
However, these diaologue activities both inside and outside of the country did not save Gülen from Kemalist scrutiny. His movement's rising power became the major sign of threat in the eyes of the secular establishment who saw the rise of religion in public sphere as a direct challenge to its very own security. On March 21, 1999, Gülen went to US for medical treatment amidst legal prosecutions.Since then Gülen was acquitted from all the charges placed against him. He still resides in the USA for over a decade without ever returning to Turkey.

In this chapter, I argued that Nur and Gülen movements focused on the Islamization of the individual because Nursi was afraid of the corrupting influences of political power. They wanted to propagate the practice of Islam without however investing all their energy in gaining control of state institutions. For example, Fethullah Gülen dedicated his life to training student whom he knew would one day have the opportunity to work in powerful institutions. He had faith that individuals and not institutions were the agents of change in society. The method he use to accomplish his Islamic program, therefore, were educational: schools, media, and publications.

Six years after Fethullah Gülen's message, a former member of Necmettin Erbakan's Islamist National View Movement, Recep Tayyip Erdoğan, founded the Justice and Development Party, promoting democratic values, human rights and a new political agenda towards the EU. In blatant disregard of the Ottoman experiences of pluralism, constitutionalism or even the traditional millet system rooted in the Ottoman Empire, essentialist scholars argued that rather than a continuation of democracy, there is

\footnotetext{
${ }^{381}$ He met with Greek Orthodox Patriarch Barthalemeos on April 4, 1996. Later On February 9, 1998 he met with Pope John Paul II in Vatican. On February 25, 1998 he met with Chief Rabbi of Israel in Istanbul.
} 
an abrupt transformation in Turkish politics concerning the place of religion in politics. It is, therefore, difficult for this kind of scholarship to understand the democratic claims of the Islamic movements. 


\section{Chapter VI: AK PARTY AND NEO-OTTOMANISM}

This chapter analyzes how and to what extent the Justice and Development Party has been influenced by all three Islamic approaches. The different modes of the Islamic approaches examined in this work lead to different interests, goals, and strategies; these all have different political implications. So, what is the relationship between these Islamic approaches (their self-definitions and political aspirations) and Justice and Development Party's ideology? A closer look at the ideas championed by AK Party and its major figures show that they are committed to transforming the country more than previous governments. Many secular leaders consider this to be a counter-revolution (karsi devrim) ${ }^{382}$

They argue that AK Party is a new version of Erbakan's Islamist National View Movement. Others argue that Erdogan's political ideology was shaped by his Naqshbandi background, which contradicted Erbakan's ideology. Recently scholars suggested that Erdogan had close ties with Nur community's Fethullah Gülen, who was seen as supportive of a US backed "Turkish Model" project favouring a moderate Islam in the Middle East. Since the AK Party came to office they have demonstrated similarities with the Islamic movements studied above. This chapter will argue that the similarity in policy making is incidental, a product of a common religious heritage and that the policies of AK Party have been sui generis, an authentic creation of its own decision makers.

\footnotetext{
${ }^{382}$ In their columns, Taha Akyol and Mehmet Barslas criticized seculars who call AK Party policies as 'counter revolution'. For more see Milliyet newspaper March 24, 2006, Hurriyet newspaper September 28, 2007.
} 
Since the foundation of AK Party, they had one major obstacle: the entrenched Kemalist military posing as "guardians of the state." 383 As a result, some scholars argued that AK Pary deliberately tried to "avoid a head-on collision with the military." 384 This case is representative of how Islamic groups react to similar events in different ways. Contrary to AK Party's predecessor Islamist National View Movement, which had deliberately popularized political slogans, the way AK Party handled its relations with the Kemalist Military was similar to the strategy pursued by the Gülen group. Naqshbandi groups, for their part, were vocal in their critique of the state, but mostly focused on their own internal social activities.

The polarization between Kemalists and Islamists in the political arena had already widened before the Justice and Development Party's electoral victories. Erbakan had previously been forced to resign from office because of a military coup. For some scholars this was indicative of Huntington's 'torn country' thesis. ${ }^{385}$ This was the first problem confronting the Justice and Development Party after its victory in the November 2002 elections in Turkey. The question was what kind of a policy the Justice and Development Party would follow within the boundaries of the Kemalist regime? Ozcan, a prominent Turkish political scientist, summaries the new identity of the Justice and Development Party:

From the very start, the JDP [Justice and Development Party] leaders contended that they are a mainstream party with conservative center-right

\footnotetext{
383 The idea of "guardians of the state" is appropriate in analyzing the role of the military in poitics. Its relevance to Turkey was studied by Tamkoc 1976.

${ }^{384}$ Ozcan 2002, 1.

${ }^{385}$ Robins 2007, 289.
} 
credentials. Party leaders continually represented themselves as successors of liberal/conservative Democrat Party of the 1950s and the Motherland Party of the 1980s in contrast to the Islamist Welfare Party (WP) and its successor Virtue Party. Party documents and official statements suggest that JDP [Justice and Development Party] is determined to take a different approach in foreign affairs than the Islamist tradition from which the leaders have hailed. ${ }^{386}$

The major difference between the Justice and Development Party and its failed predecessors was the self-conscious and active attempt by the AK Party to be a centrist party sympathetic to the demands of both political left and right. Though mostly practicing Muslims, the Justice and Development Party party members publicly declared their acceptance of the secular system. The significance of Justice and Development Party's challenge was to prove that it was not a marginal party coming from the periphery to challenge the political center but transform it from within while still holding on to centrist positions. The first major challenge to the traditional way of doing politics was Justice and Development Party's handling of the Cyprus crisis. In 2003, Justice and Development Party took an enormous political risk and changed Turkey’s forty-year long policy towards Cyprus to be in line with EU recommendations. ${ }^{387}$ This is representative of the differences between the new type of Islamist, Justice and Development Party, and the old Muslim parties. Justice and Development Party introduced new approaches to issues not ordinarily considered Islamic.

The major shift from their previous position shows that AK Party leadership acted as an active agent of change rather than representing status quo in the country and within the overall Islamic community. Their policies were a result of calculated attempts that

\footnotetext{
${ }^{386}$ Ozcan 2003, 2.

${ }^{387}$ A Turkish magazine revealed that AK Party's Cyprus policy almost caused a coup d'etat in 2004; it failed only due to a division within the army brass. Taspinar 2008, 29.
} 
have historical relevance to conservative Muslim mindset or part of a deliberate project rooted in historical depth. AK Party leadership justified their new position by referring to the richness of Turkish history with special reference to the Ottoman Empire. Therefore, AK Party's references to historical depth and its transformative impact of their ideas on Turkish politics would be difficult to understand without referring to the Neo-Ottoman ideology of the late Ottoman era. This historical connection enables AK Party leaders to have a useful toolbox that they can use both for deep-rooted tradition based identity formation and flexibility it brings with its eclectic nature. Every new reading of history is remaking it according to the conditions of the today. Neo-Ottomanism, therefore, has been a strong and reliable reference for Turks who wanted to preserve their identities in a modern world.

With special reference to the preservation of the Ottoman State, Ottomanism emerged in an eclectic way in order to incorporate Islamic principles like freedom, justice and consultation into a political arena that was increasingly dominated by the secular European concepts of the $19^{\text {th }}$ century Europe. Interestingly, Ahmet Davutoğlu, ${ }^{388}$ the architect of Justice and Development Party's foreign policy has written one of the most articulate treatments of Ottomanism and its relevance to contemporary Turkey. He gives important insight on the emergence of Ottomanism during the late Ottoman era and how

\footnotetext{
${ }^{388}$ Ahmet Davutoglu is Justice and Development Party's Minister of Foreign Affairs who is the man behind Turkey's new foreign policy. Previously he was the chief advisor in the Justice and Development Party government. He articulated his ideas on Turkish Foreign Policy extensively in a number of seminal book. Davutoglu: 2002, 2004. Bilgin, 2008 compares Justice and Development Party policies with its Islamic predecessor where she argues that new foreign policy is not Islamist. Murinson 2006 specifically examines Davutoglu's 'zero problem' and 'strategic depth' concepts.
} 
it represents similarities with today's Neo-Ottomanism. ${ }^{389}$ For Davutoğlu there are two main factors contributing to the rise of Ottomanism. As a political ideology, it emerged at a time when late Ottoman era leaders wanted to limit the influence of post-French Revolution Europe's nationalism on multi-cultural multi-ethnic Ottoman State. ${ }^{390}$

The second important factor was the emergence of the new European Order of 1815 after the Vienna Congress and the Ottoman desire to have a place in it. ${ }^{391}$ As a result, Ottomanism became an umbrella designation for the attempts to unite the Empire's dissident nations with newly coined terms like Ottoman nationality (Osmanlilik) and homeland (Vatan) while at the same time trying to keep the Empire in line with the new developments in the European order. ${ }^{392}$ The most important result of this process was the Tanzimat reforms (1839) when the Ottoman leadership began to give equal rights to its citizens and initiate reforms that eventually limited Sultan's power.

Major figures of the Ottomanist ideology were Sinasi, Namik Kemal and Ali Suavi who began to propogate their ideas actively in and around $1865 .{ }^{393}$ They were all products of Tanzimat reforms; they had secular educations in newly established European style schools where they learned western languages and concepts of governance.

\footnotetext{
${ }^{389}$ Davutoglu 2002.

${ }^{390}$ Nationalist movements were gaining among the Ottoman Empire's Greek, Bulgarian, Albanian, Serbian, Croatian, Armenian people to the North, and its Arabic population in the South. Kurdish nationalism emerged much later.

${ }^{391}$ Davutoglu 2002, 85.

${ }^{392}$ In this period the Greek War of Independence lasted nine years between 1821 and 1829 ending with the major loss of land for the the Ottomans.

393 Namik Kemal was the first Ottoman to formulate the idea of homeland that people can associate themselves with it as an ideal rather than a piece of land. Aksin 2007, 34-35; Shaw 1977, 131-132.
} 
However, they also had a deep-rooted respect for religion and tradition including the Sultan himself. In order to keep the multi-ethnic and multi-religious Ottoman State together in an era of rising nationalist sentiments, they tried to achieve Unity of Nationalities (Ittihad-i Anasir) regardless of their racial background. They believed that different nationalities and millets (people of different religions) could be unified under an Ottoman ideal which did not rely on religious allegiances but a new western concept of citizenship disseminated by a pro-Ottoman (though not Islamic) education system. ${ }^{394}$

Ottomanism argued for a free political system based on a constitution with a parliament, and limited power for the Sultan. They took their ideas about constitutionalism and parliamentary system from European thinkers (some of with whom they personally identified with) ${ }^{395}$ but they were able to modify it into an overall Islamic tradition. Free democratic system was called Nizam-i Serbestane, Constitutionalism was called Nizam-i Esasi and Parliament was called Shura-yi Ummet (Consultation of the Umma) ${ }^{396}$ which were all justified with the Islamic principles like hurriyet (freedom), adalet (justice) and mesveret (consultation). Ottomanists were instrumental, at least on the intellectual level, in bringing the Sultan Abdulhamid II to proclaim the first constitution and open the Ottoman Parliamnet in 1876.

The ideal of Ottomanism was to keep different ethnic groups and religions under one roof; it was one last attempt by the state to reassert its domination over territory which was quickly being liberated by nationalist movements. With the advance of the

\footnotetext{
${ }^{394}$ For more see Aksin 2007, 82- 83.

${ }^{395}$ Shaw 1977, 130.

${ }^{396}$ Eris 2002, 597; Shaw 1977, 130.
} 
Balkan War in 1912 and consequent independence of Balkan States from the Ottomans, Ottomanism became a bankrupt ideology. Following WWI (1914-1918), the War of Independence (1918-1922), and the establishment of the secular republic in 1923 nationalism rather than Ottomanism became dominant. Ottomanism's rise became visible only after the 1980s when Turgut Özal, a former Naqshbandi bureaucrat, came to power together with the support of a public which was aware of the Ottoman past. The gap between the decline of Ottomanism in the beginning of the century and its re-emergence at the last quarter of the century with the government of Özal can only be explained by the activities of Islamic movements examined in the previous chapters.

Turgut Özal's Prime Ministry, beginning in 1983, was a cornerstone in the liberalization policies that diversified the traditional business and bureaucratic elite in Turkey. During Özal's era Turkey began to see the rise of a new Muslim bourgeoisie. ${ }^{397}$ Özal himself was a Naqshbandi. His mother and especially his brother Korkut were very close to the Naqshbandi shaikh Zahid Kotku. ${ }^{398}$ His liberal ideas in economic life ${ }^{399}$ and lavish life style of his family often times gave mixed signals about his orientation but Özal's relationship with Islamic communities was not limited to Naqshbandi tariqah. He was also a member of Erbakan's National Salvation. More recently, Özal had become an ardent supporter of the Gülen movement. During the Özal era all Islamic movements

\footnotetext{
${ }^{397}$ Yavuz 2004, 224.

${ }^{398}$ When his mother died, with a special approval from the cabinet of Ministers she was buried right next to the Naqshbandi sheikh. For more on the relationship between Özal family and Naqshbandi sheikh see Özal 1999.

${ }^{399}$ For a critical reading of Özal's economic policies, see Önis 2004.
} 
gained ground. This was already an ongoing trend but the late 1980s was better suited to the advancement of the political prestige of Islamist groups ${ }^{400}$

Turkey's increasing involvement in the Balkans led to academic debates on NeoOttomanism. Concurrently, famous Turkish historian Kemal Karpat argues that the term Neo-Ottomanism was first used by Greeks (not Turks) when Turkey landed its forces in Cyprus in $1974 .{ }^{401}$ In its inception, Neo-Ottomanism reflected how Turks were viewed by their neighbors; the term then carried over into Turkish views of themselves. Therfore scholars like Tunander and Constantinides focus solely on Neo-Ottomanism's foreign policy aspect mostly in terms of its involvement in the Balkans. They argue that any Islamic reference in foreign policy is a representation of its Ottoman aspirations in the region which they identify as Neo-Ottomanism. ${ }^{402}$ By focusing solely on Özal's policies during his tenure in the 1980 s, these authors overestimated the direct link between the Turkish state's decision makers and Neo-Ottomanism in Turkey.

Scholars misread two major events during Özal's tenure; these events both triggered debates on the rise of Neo-Ottomanism in Turkey. First, the 1986-1989 Bulgaria crises. Because of their Muslim identity, over three hundred thousand Muslim Turks from Bulgaria were forced to either leave the country or assimilate. The Özal government accepted all the immigrants coming from Bulgaria. Besides handling the massive human movement into Turkey, an important part of the negotiations between Turkey and Bulgaria was about famous Bulgarian Heavy Weight lifter Naim

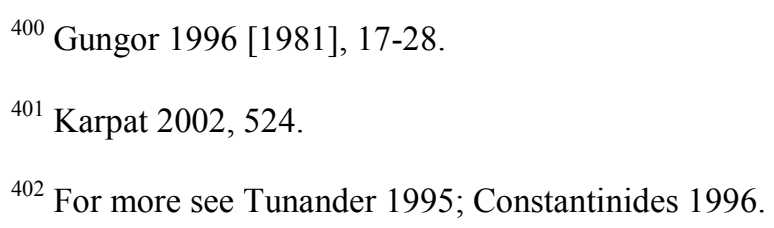


Suleymanoglu. Suleymanoglu was of Turkish origin and Özal reportedly paid between four to seven million dollars to the Bulgarian government for his release. Politicians and journalists at the time criticized Özal for his attempts. Özal thought that he was doing it for the image of Turks but many people around him did not share his ideas. ${ }^{403}$ The second important event happened a few years after this ciris. The Bosnian war began in April 1992; Özal again tried to play an active role, this time he was President. To show the solidarity of the Turkish people with Bosnians, in February 13, 1993 Özal attended a famous protest in the heart of Istanbul. Although he was the highest-ranking politician in the state, his attendance in the protest did not find coverage even in the state run television. The commonaility of both of these events was that these events involved Muslim Turks in former Ottoman lands in the Balkans, and Özal tried to play an active role; most of the time he had to convince or force people around him to follow his policies.

Neo-Ottomanism is a reconstruction of the Turkish identity together with two important factors. First, after Özal era Islamic movements were more able to influence and act in transforming the limited interpretation of Kemalist Turkish nationalism and bring forward the Ottoman heritage as a more inclusive framework. Neo-Ottomanism acknowledges the fact that religion has been an integral part of Turkish society and that Islam is not necessarily an anti-western ideology. This understanding of religion requires more space for religious expression than the relegating interpretation of the secular establishment in Turkey. Syncretistic notions of religion and state have also existed in

\footnotetext{
${ }^{403}$ For more on the details see the interview with Özal's Minister of Economy in the Turkish newspaper Hurriyet December 5, 2009.
} 
Turkey; the "Turkish Islamic synthesis" is one of the major examples. ${ }^{404}$ However contrary to "Turkish-Islamic Synthesis's" nationalist vision, ${ }^{405}$ Neo-Ottomanism deals with issues current in the late Ottoman and contemporary period, though with a diminished emphasis on the state as the agent of change in Turkey. In fact, the most important aspect of Neo-Ottomanism is its unique treatment of the relationship of religion with the secular state.

The inability of the Kemalist regime to co-opt religion into the governmental system and provide a widely accepted national identity led Muslim populations into NeoOttomanist religious expression with stong elite and intellectual support. This intellectual background of Neo-Ottomanism is similar to Conservatism as a middle way between the changes of modernity and tradition. It is not totally against change; nor is it blindly accepting of westernization. By following such a conservative perspective NeoOttomanswere able to practice their faith and still live happily in a Kemalist secular democracy. ${ }^{406}$ Young Muslims were able to find in the Ottoman-Turkish experience an ideal of the past. It provided practicing Muslims with the tools necessary to reform the ideological bonds of Kemalism. In this sense, although Neo-Ottomanism is not statist or Nationalist, it still does not question the legacy of Ataturk. Rather, its proponents defend the possibility of reading Kemalism in a different way. As Taspinar states, therefore,

${ }^{404}$ Cetinsaya 1999.

${ }^{405}$ Savvides 2000, 65.

${ }^{406}$ Ömer Caha argued that in his field research in Anatolia he constantly saw houses and businesses where Muslim Turks voluntarily hanged the pictures of Ataturk on the walls next to pictures of Kaba or an Arabic verse. Caha categorically rejected the idea of Mulims in Turkey being against Mustafa Kemal Ataturk and argued that Muslims in Turkey were able to accommodate both allegiances in one identity. Personal communication with the author in November 22, 2006 Istanbul Fatih University. 
Neo-Ottomanism wanted the Kemalist republic to be at peace with its Ottoman past. This process is not an Islamization at the expense of Ataturk legacy but a sign of correction of excesses associated with high Kemalism. ${ }^{407}$ It is interesting to see that Neo-Ottomanism allowed Muslims in Turkey to co-opt Ataturk after it had become clear that Ataturk and the secular establishment he founded were unable to co-opt Islam.

As a politician who lived during turbulent times, Ataturk left a legacy on almost all aspects of Turkish life. ${ }^{408}$ Kemalist elites envisioned a strictly controlled militaristic country $^{409}$ that followed an exclusively westward looking foreign policy. ${ }^{410}$ Therefore, Turkey distanced itself from its Ottoman past in the Middle East and the Balkans, ${ }^{411}$ as well as from the Turkish speaking states of Central Asia. ${ }^{412}$ The post-Cold War emergence of Central Asian Muslim states and the Balkans gave Muslims in Turkey the means to reconnect with modern international developments. Kemalist ideology had failed to address these developments to the deep disappointment of the general public. ${ }^{413}$

\footnotetext{
407 Taspinar 2008, 3.

408 Ataturk's seminal work Speech (Nutuk) is a prime example. Although Ataturk set his nationalist and secular manifesto in this auto-biographical statement he also mentioned that Turkish society has elements of Islam (Anasir-I Islamiye) rather than a pure Turkish Nation which has later become the main principle of Kemalism. Recep Tayyip Erdogan quoted Ataturk's Speech when he initiated his the Kurdish Question reforms.

${ }^{409}$ The contribution of famous Kemalist Recep Peker in this process is undeniable.

${ }^{410}$ Taspinar 2008, 2.

${ }^{411}$ Constantinides 1996, 332.

${ }^{412}$ Rouleau 1996, 69.

${ }^{413}$ In the aftermath of the Cold War it was mainly the Gülen community that actively engaged with Bosnia and the Central Asian states while the secular elite distanced themselves from both of these areas, even Central Asia which has national ties.
} 
The Justice and Development Party experience in Turkey becomes more significant than the Özal era because the Justice and Development Party leadership have more public and elite support from the Muslim bases. On the other hand, they seem more unified in their Neo-Ottomanist vision than the sporadic attempts of the Özal era. They were able to connect themselves to the late Ottoman era by showing that there are important similarities with contemporary Turkey. Justice and Development Party's NeoOttomanism is the result of independent Muslim intelligentia. These Muslim scholars were highly educated, did postgraduate work and were fluent in one or two foreign languages. The most important one is Professor Ahmet Davutoğlu.

Justice and Development Party's foreign Minister Davutoğlu is an independent scholar rather than a representative intellectual of any religious movement or ideological school of thought. ${ }^{414}$ Davutoğlu's situation makes the relationship between Islamic movements and the Justice and Development Party government more interesting. Tayyip Erdoğan has always preferred to work with these types of intellectuals because of their scholarly credentials and independent characters. As a politician, Erdoğan did not want to have orthodox religious oversight over him. In that regard he is similar to Erbakan. However, Erdoğan's main difference from Erbakan was that he gave close consideration to the analysis of his advisors rather than formulating positions based on personal prejudice and emotion.

\footnotetext{
${ }^{414}$ Davutoğlu graduated from Bosphorus University, receiving his Ph.D. under the supervision of Serif Mardin, the leading scholar on Religion and politics in Turkey. His initial focus was the Islamic Weltanschauung, its makeup and contribution to other civilizations which helped Davutoglu develop his ideas on Neo-Ottomanism. Early on Davutoğlu directed his scholarship to develop Islamic solutions to Turkish and modern problems.
} 
Moreover, Erdoğan and the scholars around him are not bombastic or blatantly ideological like Erbakan, and this seems to suit the new brand of Turkish Islamist first seen during the Özal era. Interestingly enough the place of religion in the current Turkish case resembles Turkey's Ottoman example where, as we have seen in the previous chapters, political elites have constantly been jealous of their position and tried to keep the religious elite under control. In Turkish history the place of religious elites in any setting, be it Ottoman or Neo-Ottoman, has been secondary to the political office. In that regard Neo-Ottomanism is direct continuation of its Ottoman predecessor.

In his writings Davutoğlu viewed Islam as the backbone of the civilization it created and inspired rather than a religion understood restrictively. This enabled him to develop a language more open to an international audience. He was able to speak the civilizational language of Islam which could be recognized and respected across borders and cultures. After receiving his doctorate, Davutoğlu chose to teach in Malaysia, a Muslim country, rather than accepting a teaching position in the United States. His years in Malaysia helped him to understand the varieties of Islamic self-expression among contemporary Muslims. His main accomplishment was to develop an international curriculum intended for students from diverse backgrounds. ${ }^{415}$

After returning to Turkey he utilized his experiences mainly in the Foundation for Science and Art (Bilim ve Sanat Vakfi, BISAV), a non-profit think-tank. During his time there BISAV became the center of meaningful debates, where leading scholars attended public lectures and courses. BISAV acted like an informal university with a graduate

${ }^{415}$ Author's personal note from Davutoglus's lecture in his foundation. February 2001. 
level curriculum appealing to a young generation of mostly moderate Muslims. At the same time he taught International Relations at Marmara University and later, until entering the current Turkish government, he served as the head of the international relations department at Beykent University. His interests embrace not only politics and international relations, but also philosophy, history, geography, especially its specialized branch geopolitics, as well as cultural studies and economics.

He mentions five major similarities: (i) reconfiguration of the state body in line with the international system; (ii) attempts to form new political identity and culture in order to respond to rising nationalist demands; (iii) trying to keep a balance between the new thinking and the traditional values; (iv) attempts to integrate into the European system (European System in the post-Vienna Settlement and EU, respectively); (v) harmony with the superpowers of the time (Britain and US, respectively). ${ }^{416}$ These issues and how AK Party handled them can best be understodd when we see how Davutoğlu defines his idea of self.

Davutoğlu's most important contribution to the literature is his studies on the "self-conception of civilizations" which served as the philosophical foundation of his later writings on foreign policy. ${ }^{417}$ His works suggests that Islamic identity is ontological rather than social:

The main factor of this universality of the Islamic civilization is an ontological consciousness which directly penetrates each individual

\footnotetext{
${ }^{416}$ Davutoglu 2002, 85. For a selection of interviews with Davutoglu on Neo-Ottomanism see Davutoglu 2006 [2002].

${ }^{417}$ The nucleus of Davutoglu's foreign policy approach appeared in an article titled "The Clash of Interests: An Explanation of the World (Dis) Order" in 1998. However, Davutoglu's ideas on 'self-concept,' although not directly foreign policy pieces, were published before this article.
} 
human mind regardless of his ethnic and regional origin. Common cultural and political responses to colonialism and modernity in different parts of the Muslim World are themselves the indicators of this consciousness. The rise of Islamic identity and its socio-cultural reflections in these lands which were recently governed by atheist Soviet authoritarianism serves to confirm the impact of this ontological consciousness. ${ }^{418}$

Davutoğlu argues that contrary to the majority of modernizing efforts, civilizations like Islam persisted due to a 'core' that they had which is not appreciated in current theoretical discussion. He argues that since the 1980s policy oriented studies began to follow structural explanations, focusing solely on external factors affecting Muslim communities rather than "internal dynamics based on mindset formation," resembling what Serif Mardin calls the "internal spring" of Islamic identity. ${ }^{419} \mathrm{He}$ has used this concept to analyze Muslim societies and has argued for its use among scholars of the Muslim world. His work is critical of the scholars who use structural explanations in analyzing the Islamic world.

Davutoğlu's discussion of self-concept makes up the core of Neo-Ottomanism and counters many scholarly formulations which give primacy to the construction of an external other in identity formation. Mesbahi explains this characteristic of the new Turkish Foreign Policy as follows:

Turkey is a self-referential international 'visionary' actor, an actor on the world stage purposefully and deliberately (not reactively) embracing the world, its challenges, and opportunities and a conscious agent with a particular set of ideas and positions worthy of playing on the world stage. This is a major ideational and temperamental/psycho-political change about what foreign policy actually is, what its functions and purposes are, and what Turkey actually means to the world polity; a change that only a

\footnotetext{
${ }^{418}$ Davutoglu 1997.

${ }^{419}$ Mardin 2005.
} 
new elite, a new group of constructivist agents with a different selfperception could introduce and construct. ${ }^{420}$

Davutoğlu argues that "identity is based on social recognition and requires two parties while self-concept represents individual consciousness that does not require/need social recognition." ${ }^{421} \mathrm{He}$ attempts to define the self-concept of the actor without referring to the inherent place of "other" in western identity formation. For him human nature has, by definition, qualities that resist social forces and resurface back, even after long periods of suppression where the self-concept was not able to accomplish its selfreferential qualities. This is the modern equivalent of Ihsan as expressed in the hadith of Gabriel. Living with God-consciousness, actors should act according to certain criteria even during hostile environments. In his formulation of Islamic self-concept he is not alone.

A theology professor and another member of the Justice and Development Party cabinet, Mehmet S. Aydin, had expressed a number of similar ideas. He argued that Islam does not need to construct values in opposition to other value systems. Islam is based on the idea of God as creator and Lord, and Islamic values come from this theological premise. For him Islam is the "inner core" of the Turkish cognitive map. ${ }^{422}$ Due to the difficulty in formulating a "metaphysical" ontological position in secular scientific language, in his formulation of the self-concept Davutoğlu stops short of saying that the ontology of the self-concept comes from Islam.

\footnotetext{
${ }^{420}$ Mesbahi 2010.

${ }^{421}$ Davutoglu 1997, 11.

${ }^{422}$ Aydin 2002.
} 
Ottoman-Turkish experience has become a valuable reference tool for Davutoğlu in understanding the behavior of Muslims in Turkey. Ottoman references to justice, freedom and its treatment of religious minorities (mainly Orthodox Christians and Jews) under the Ottoman Millet system (which was derived from classical Islamic laws concerning religious minorities) have become the major points in his re-construction of Self-Concept and its policy implications. Similarly, Hakan Yavuz argued that religions are integral parts of human societies, providing the model of how to live. ${ }^{423}$ His treatment of the emergence of religious identities is shaped primarily by structural factors, contradicting Davutoğlu's claim. Yavuz's perspective subordinates the ontological approach to structural considerations. There would then be no need for a foundational base upon which identity and action spring; structural approaches analyze identity with exclusive reference to external developments.

For Davutoğlu self concept is not culture specific. Therefore, what he calls NeoOttomanism is only Turkish implementation of a universal set of values. This brings the question of whether he tries to 'export' his ideas to other Muslim countries with common Islamic backgrounds. "Turkish Model" explanations that have emphasized the strict secular control of the public sphere ${ }^{424}$ are at odds with Davutoğlu's pluralist reading of the Neo-Ottoman legacy. Because Davutoğlu sees the self-concept as an ontological position it can only be remodeled by ready recipient actors rather than exported by the conveyors. $^{425}$

\footnotetext{
${ }^{423}$ Yavuz 2004, 213.

${ }^{424}$ Kitfield 2002

${ }^{425}$ The so called export of the Iranian Revolution is an example of this.
} 
Neo-Ottomanism is not only a foreign policy making principle but also the core component of the Turkish State's new identity during the Justice and Development Party era. Davutoğlu and his Neo-Ottoman policy came to the center of political power in Turkey. As stated in the party program, the Justice and Development Party is cognizant of globalization and post cold war developments. ${ }^{426}$ The first major issue in the party is regional cooperation, followed closely by relations with the EU, Islamic countries and strategic and defense relations with the USA. These policy preferences were the product of Ahmet Davutoğlu. Although Justice and Development Party and Davutoğlu have faith in a dedicated EU path they are cautiously optimistic. In a statement before his ministerial post, Davutoğlu argued that the EU will not accept Turkey's membership but will try to keep it at its gates (probably with a special membership). Davutoğlu argues that Turkey cannot wait forever at the EU door, and needs to develop a genuinely multidirectional foreign policy by utilizing its geostrategic advantages.” 427

Euro-scepticism is the main factor inducing Turkey to improve its relations with its neighbors. Davutoğlu's “'strategic depth' doctrine calls for an active engagement with all regional systems in Turkey's neighborhood. Turkey needs to rediscover its historic and geographic identity and reassess its own position vis-à-vis regional and global issues." 428 "Davutoğlu called for a re-engagement with the Middle Eastern region, in particular with Iran, Syria and the Gulf States. In the Balkan region he stressed the importance of Greece and Bulgaria, while in Caucasus he pointed to the robustness of

\footnotetext{
${ }^{426}$ AK Parti 2002.

${ }^{427}$ Murinson 2006, 952.

${ }^{428}$ Murinson 2006, 953.
} 
Georgian-Turkish relations." ${ }^{429}$ Turkey's economic and foreign relations with regional countries have experienced their peak during the tenure of the Justice and Development Party government. This regional and international orientation that the Justice and Development Party government aspired to develop is a major break from Erbakan's foreign policy of Islamic identity. Erbakan stressed the importance of regional relations with Islamic countries and his policy choices were strictly anti-western rather than diverse. During his career Erbakan spoke against Turkey's relations with the US and $\mathrm{EU} ;{ }^{430}$ he never supported relations with regional countries other than Muslim ones.

According to Davutoğlu's primary foreign policy principle, due to its historical and cultural background Turkey is a "Pivot Country." ${ }^{\text {"31 }}$ For him the cultural and political legacy of the Ottoman Empire makes Turkey both Western and Islamic geographically and culturally. Turkey borders many of the key regional players such as Iraq, Syria, and the Central Asian republics, so it has a responsibility in these areas, together with Balkans and Caucasus and Eurasia region, to be engaged in many controversial issues. The Justice and Development Party was able to successfully engage in and address the important metropolitan issues in Istanbul. They feel confident that they could have the same kind of success on the international stage.

The major turning point in Turkey's new foreign policy under Davutoğlu was with the US. From the start of their tenure in office Justice and Development Party tried

\footnotetext{
${ }^{429}$ Vatan news cited in Murinson 2006, 953.

${ }^{430}$ Robins 2003, 145-146.

${ }^{431}$ Davutoğlu 2002.
} 
to maintain good relations with the US, despite critical policy issues affecting bilateral relations. It was quite symbolic that Erdoğan's first international debut was staged in the White House. However, Turkey's direct involvement in Iraqi problems put itat odds with the US on many issues. Post 9/11 US foreign policy emerged as unilateral and hegemonic. Bush's uncompromising policy was a major challenge to those who dared to qualify their involvement in America's war on terror. The war on terror emerged at a very critical juncture in Turkish domestic politics. When the Bush administration began to toughen its diplomatic language against Iraq, Turkey's new government began to worry about instability in the region and future problems. In order to seek a westward looking foreign policy Turkey needed predictability, security and regional stability.

Based on the experience of the first Gulf war an instable Iraq meant an instable Turkey, if not the entire Middle East. Turkey did not support direct military involvement in Iraq but was asked by the US to allow troops to enter Turkish territory in expectation of an invasion. Erdoğan specifically expressed his willingness to support the bill authorizing US forces to deploy in Turkey in order to invade Iraq from the northern front. However, he was caught in the political crossfire in the parliament, both from the opposition and his own party's MPs alike. ${ }^{432}$ All Islamic communities were against the bill as well. Fresh from the election civil society groups from all strands of the society lobbied to have the bill rejected. As a result, on March 1, 2003 the bill was rejected in the parliament. The rejection of the bill in the parliament was a shock not only for the US but for Erdoğan himself, who at the initial statges of his Prime Ministry did not know what

${ }^{432}$ Ozcan 2003, 4. 
kind of a policy to follow. Scholars give two different explanations of this situation. First Erdogan either wanted to support the US initiative to be part of the operation and have a say over US policies in Iraq.

One major long-term, unresolved issue has been Turkey's relations with EU. The Justice and Development Party came into power with the specific goal of improving Turkey's prospects for EU membership. ${ }^{433}$ They "enthusiastically worked to implement the National Program drawn up by the previous government in 2001. The Program required Turkey to comply with the EU's Copenhagen Criteria, namely, the rule of law, respect for human rights and advocacy of a free market economy. Major packages of reforms were passed through parliament in an effort to bring the legal system in line with the EU policy." 434 The Justice and Development Party government has shown its commitment to democratization and Turkey's EU membership process from the beginning of its tenure in office. This is both a continuation of previous policy and a dedication of Justice and Development Party's decision makers. ${ }^{435}$

Before he became Prime Minister Erdoğan began visiting European capitals in order to urge EU leaders to set a definite date for the commencement of accession negotiations at the December 2002 European summit in Copenhagen. His attempt to secure a date failed but it established him as a leader wedded to the idea of Turkey's EU bid in the eyes of European leaders such as Schroder, Berlusconi and Blair. ${ }^{436}$ This

\footnotetext{
${ }^{433}$ Ozcan 2003, 2.

${ }^{434}$ Ozcan 2003, 5.

${ }^{435}$ Yavuz 2006; Duran 2006.

${ }^{436}$ Robins 2007a, 292.
} 
helped the Justice and Development Party on other fronts. First, it enhanced the relationship between the EU and the Justice and Development Party where the Justice and Development Party was able to establish a positive image in the eyes of western political circles where political Islamists had previously had a negative image. This young generation of Islamists demonstrated that EU membership was not antithetical to being an activist Muslim in both a democratic and pluralistic world. Secondly, EU began to function as a shield against the antidemocratic forces in the country in Justice and Development Party's favor. ${ }^{437}$

In line with the Neo-Ottoman foreign policy, the Justice and Development Party leadership demonstrated its commitment to EU ideals by completing at least seven harmonization packages by $2003 .{ }^{438}$ On 6 October 2004, the EU Commission in its annual Regular Report on Turkey indicated that Turkey had fulfilled the Copenhagen political criteria and recommended that the Council open accession negotiations with Turkey. After tough negotiations at the EU Council Summit on 17 December 2004, the Council decided to start the accession negotiations with Turkey on 3 October $2005 .{ }^{439}$ However, after 2005 AK Party's commitment to the accession waned. After 2006 AK Party members began to voice their dissatisfaction with the process by criticizing the EU for not being honest with Turkey's membership. Often times the rhetoric brought back memories of the reactions of nationalist parties in the country to whom AK Party itself

\footnotetext{
${ }^{437}$ Robins states that "the Justice and Development Party had come to see the EU as 'a shield' behind which to shelter. Post-Islamists and Kemalists had come to face in the same direction as far as foreign policy priorities and the EU was concerned." Robins 2007a, 292.

${ }^{438}$ Robins 2007a, 292.

${ }^{439}$ Murinson 2006, 945.
} 
was opposed. The mixed messages coming from AK Party elite showed cautious commitment which came from its Neo-Ottoman background. It is apparent that AK Party does not want to link itself to EU at the expense of its other objectives in the rest of the region; the AK party wants to extend its regional alliances beyond the specific confines of EU membership.

One of the major foreign policy issues faced by the Justice and Development Party government has been its relations with Israel. Turkey's relations with Israel are linked to the state of the Palestinian-Israeli conflict. Turkish-Israeli relations are an issue of religious conscience, with most Turks strongly sympathetic towards the Palestinians. The main premise of a social identity analysis is that religious and cultural links propel Turkish people to support the Arab cause against Israel. ${ }^{440}$ As a result, it has been argued that a foreign policy issue like the Palestinian problem is an extension of the domestic divide between the secular rulers and the Muslim population. ${ }^{441}$ With regards to antiSemitism, the Justice and Development Party has displayed a different attitude than former Islamist parties. From the beginning, it has not resorted to anti-Semitic discourses and has liberated itself from the ideological burdens it inherited. Addressing the Organization of Islamic Countries in Malaysia in October 2003, then Foreign Minister Abdullah Gul denounced anti-Semitism. ${ }^{442}$

The question of Palestine became a major issue during the Justice and Development Party era, a result of greater visibility of Islamic sentiments in the political

\footnotetext{
${ }^{440}$ Bacik 2001; Aras 2000.

${ }^{441}$ Yavuz 1997b.

${ }^{442}$ Ozcan 2003, 3.
} 
arena. AK Party's foreign policy towards the Palestinian issue is important due to a couple of other developments. First Israel's attacks on Gaza and Jenin were seen as unacceptable in Turkish public opinion. Secondly, the 9/11 attacks made the issue more critical for Muslim and western countries in an age of global and state-sponsored terrorism. Since Prime Minister Bulent Ecevit ${ }^{443}$ called Israeli policy towards Palestinian civilians' genocide, Turkey's relations with Israel began to deteriorate. ${ }^{444}$ Ariel Sharon's Prime Ministry and his assertive policy against the Palestinians were not accepted by even a secularist agnostic like Ecevit. The position of AK Party government, which came to office after Ecevit, were intensified because he represented the moral sentiment of the majority of Turks, as well as the specific discontent of believing Muslims. The first issue that involved Turkey and Israel would be the Turkish Al Qaida's attack on the Synagogues in Istanbul in November 2003. Erdoğan visited the chief rabbi Ishak Aleva in December 2003 becoming the first Turkish premier to visit the Jewish community since the establishment of the Turkish Republic. ${ }^{445}$

Erdoğan's sympathy towards Turkish Jews, however, did not extend to Israel. When Israeli forces shot and killed Hamas leader Sheikh Ahmed Yasin in March 2004 Erdoğan strongly denounced the attack. ${ }^{446}$ The same strong language continued when Israeli incursions into Gaza in May 2004 caused an outrage in the country. Erdoğan

\footnotetext{
${ }^{443}$ Ecevit, a center left politician known for his commited secularism both in his personal and political life, led the $57^{\text {th }}$ government between May 1999 and November 2002 before AK Party came to power.

${ }^{444}$ Ecevit openly condemned Israeli attacks to Palestinians as "Genocide." Zaman newspaper April, 5 2002; Radikal newspaper April, 52002.

${ }^{445}$ Friedmann 2007, 623.

${ }^{446}$ Robins 2007b; Akcakoca 2009.
} 
called Israel's Gaza policy "state sponsored terrorism." ${ }^{447}$ It would be a year before Erdoğan made a visit to Sharon in Israel. In the visit, both showed their tough side by focusing on the Palestinian issue. Erdoğan's innovative political style even made Ariel Sharon surprised, as he offered novel solutions to the conflict. ${ }^{448}$ In the case of his remarks in Israel, at the time it was not made public but later in September of the same year Turkey mediated a deal between Israel and Pakistan, which did not have official relationship.

This kind of political maneuvering in controversial areas resembles neither the policies of any Muslim grassroots movement nor the National View movement that preceded the Justice and Development Party. It is uniquely a product of the Justice and Development Party government and the pragmatic leadership of Erdoğan. Among grassroots Muslim movements there is only one that has engaged Israel in a comparable manner. The followers of Fethullah Gülen, with their highly institutionalized media outlets and non-profit organizations, have established positive relations with their Israeli counterparts at the civil society and bureaucracy level. The results of these relations repaired the image of Gülen in the eyes of the Israelis. Even in the semi-pro-Israeli journals like Middle East Forum and Meria there were positive articles calling Gülen the face of liberal Islam in Turkey. ${ }^{449}$

\footnotetext{
${ }^{447}$ For a critical reading of the Neo-Ottomanism and Turkey's relations with Palestinians see Rubin 2004.

${ }^{448}$ Soon after the meeting, Israel established first ever official relations with Pakistan with the help of Erdogan government.

${ }^{449}$ Aras 1998; Aras and Caha, 2000.
} 
The honeymoon between Israel and Turkey, however, did not last long, especially after the Israeli incursions into Gaza after the Hamas victory and its attacks on Hezbollah in Lebanon, resulting in a high number of civilian casualties. The Justice and Development Party government clearly sided with Hamas after the January 2006 election victory and argued that there cannot be a solution to the Palestinian problem without considering Hamas. Supporting Hamas and establishing direct contacts with Hezbollah have been the most risky political decisions in the Justice and Development Party engagement in the region where even Iranian and Arab leadership worry about being represented as terrorist by the US. It created an aura of suspicion around the Justice and Development Party leadership about a hidden Islamist agenda. For some it was a clear sign that Islamists were only superficially pro-western. They critically argued that the Justice and Development Party's "Zero Problem with neighbors approach" did not include Israel.

The determinants of what makes AK Party's ideology come down to its unique treatment of of Islam. It is evident that AK Party is proud of its Muslim past. However its identity is not confrontational in the sense that secularism is viewed as a threat. Their Neo-Ottomanism does not use religion as an ideological weapon to get power or intimidate opponents into sunmission; it is a representation of Turkish identity. While practicing the religion on their own, side by side with their political or professional activities, AK Party elite recognized that the rhetorical use of Islam has only limited benefits and has to be accompanied or substituted by direct and effective action. 


\section{Chapter VII: CONCLUSION}

Islam has been understood, articulated, and practiced in as many ways as there are Muslims. It has both a shared history as well as many different specific histories. ${ }^{450}$ According to Piscatori "if we want to know about Islam today, we must think of it more as conduct than as theology and doctrine" 451 because what Muslims understand of the sacred texts and traditions and how they represent their religion is relative to place, time, and context. ${ }^{452}$ This study has been concerned with organizing and presenting a typology of Turkish Islamists using a religious source, a saying of prophet Muhammad, the Hadith of Gabriel, as the conceptual framework. The analysis concluded with the newest and undoubtedly most successful Islamist actor in Turkey, the Justice and Development Party. After coming into power in a landslide election in 2002 the Justice and Development Party, comprised mainly of self-professed Muslim politicians, had to deal with the pressure of identifying with Islam in a reactionary secular state.

The saliency of the Islamic movements and their different approaches to politics in Turkey has to be recaptured in analyzing the transformation of Islam and politics in Turkey. The Naqshbandi tradition constantly tried to influence the political decision making from without while Islamist National View, although a Naqshbandi movement, argued for direct involvement in politics. Nur-Gülen movement, the third approach that examined in this work, had a strictly apolitical position by focusing on religious service at the public level. Opening educational institutions eventually had political implications

\footnotetext{
${ }^{450}$ Felipe Fernandez-Armesto speaks about "Civilization” in a similar way in Hall and Jackson 2007, 1.

${ }^{451}$ Piscatori 1988, 10.

${ }^{452}$ Piscatori 1988.
} 
when people inspired by Nursi's and Gülen messages began to influence politics. All of these groups had access to the Justice and Development Party ranks to variying degrees. However, none of the Islamic groups studied above has more than a limited influence on the Justice and Development Party. The leaders of the Justice and Development Party are conscious of the influences upon them, and appreciative of those sources of thought and inspiration, but are not dependent on them in any way.

Justice and Development Party leaders were underestimated in their ability to deal with secular issues as well as over-exaggerated in terms of their religious allegiances. ${ }^{453}$ They were a product of late Ottoman thinking but not a direct continuation of it. The diversity in the Islamic approaches as in the typology developed here is personified in the Justice and Development Party's mixed identity. From the place of religion in politics to the treatment of state as a secular apparatus Justice and Development Party tried to synthesize a vast legacy in a turbulent time. The term Neo-Ottomanism, therefore, is appropriate in defining Justice and Development Party's position. Neo-Ottomanism puts less emphasis on the state as an agent of change in society. In Neo-Ottomanism, more attention was paid to the development of individuals and promoting a social environment wherein plurality of Ottoman legacy was practiced. When it comes to relations with EU or Israel, often the Justice and Development Party gave conflicting messages. This quality of the Justice and Development Party can only be addressed within the eclectic framework of Neo-Ottomanism. Neo-Ottomanism enables us to look at both the actors and their environments rather than given primacy to one over the other.

\footnotetext{
${ }^{453}$ None of the 'founding fathers' of the Justice and Development Party has direct Naqshbandi or NurGülen connection.
} 
Serif Mardin has written about an Islamic core based in the sacred texts and religious practices of Muslims. ${ }^{454}$ To him, the special characteristics of the TurkishOttoman case requires a renewed focus. As Mardin states

"... the specifics of Turkish history have endowed the Ottomans and the Turkish Republic with characteristics that have worked cumulatively to create a special setting for Islam, a setting where secularism and Islam interpenetrate, which of course is quite different from saying that Islam and secularism have fused. This interpenetration or overlap is the real methodological obstacle that faces the investigator of Islamic modernism in Turkey. It establishes a field for study that shows much more complexity than the research based on the essentialism of Islam, the core of contemporary studies of "political" Islam in Turkey and elsewhere." 455

The Turkish context that enabled the 'interpenetration' of Islam and Secularism has not been dealt with in any detail in the primary literature on religion and politics in Turkey. The greater part of the scholarship on the Justice and Development Party erroneously attributes its origins to Necmettin Erbakan's Islamist National View Movement. This argument limits the scope of Islam's experience with politics in Turkey to one political movement because of Justice and Development Party's association with Islamist National View Movement. In fact, the Justice and Development Party is unique in that it has been influenced by many types of Islam in Turkey. One reason for the success of the Justice and Development Party is that they have balanced their deep faith in Islam and commitment to Islamic causes such as justice and peace with the political and social requirements of a secular life in a secularist state. They have made themselves

\footnotetext{
${ }^{454}$ Davutoglu did his Ph.D. on Islamic worldview where he developed his self-concept theory under Serif Mardin's supervision.

${ }^{455}$ Mardin 2006.
} 
indespensible to the welfare of secularism in Turkey while also acting as model Muslim politicians.

The typological framework offered above based on the Hadith of Gabriel divided the Islamic experience into three broad categories. The first is that of Shariah, the outward manifestation of Islam. It was described by the prophet Muhammad in terms of the five pillars, or minimal obligations of all Muslims. The second sphere was that of Iman, or tariqah. It was described as a deeper internalization of faith and the belief in the articles of faith. I used the religious orders as examples of Iman because they have traditionally institutionalized the spirituality of Iman in the form of Sufi brotherhoods. Lastly, there was the haqiqah, described as worshipping God as if one could see Him. This is the highest level of religious expression in Islam and it has been manifested in Turkish society in the persons of Said Nursi and Fethullah Gülen.

This view of the Justice and Development Party as merely an extension of the National View Movement, having an "other based" anti-western identity, assumes that the influence and role of Islam in Turkey is external and generic, rather than authentically Turkish. I would argue, alternatively, that secularism is a structural force introduced from without, yet exercising an unrepresentative role on Turkish life and identity. Secular notions of nationalism entered the common imagination of Turkish people mostly in the last two centuries, though most scholars in the Western world consider it to be constant and normative, rather than as part of an unsettled debate within Turkish society.

This study showed that contrary to the fundamental reforms and secularization projects Islam is still a constant in the minds and hearts of the Turkish people. Contrary to all the changes in the republican era "the influence of the moral culture of Islam, its 
voice, was still around as an autonomous force given the lackluster ethical message of the Republic." ${ }^{" 456}$ The modern imagination of the Republican era was not able to fill the ethical or the moral void that the Turkish society had felt for decades. Hence it was the moral culture which shaped Islamic grassroots movements for decades which many Justice and Development Party members embraced after they separated from the National View Movement.

Turkish political history shows us that Islam has been an integral part of the political and social imagination among Turks, though after the fall of the Ottoman Empire and the establishment of the Republic that voice had been systematically suppressed by the state. It can be argued that no viable long-term social or political imagination can exist in Turkey without having to merge or coexist in some way with Islamic actors and their ever-present voice. Much of the scholarly literature on Turkey in the modern era has normativized the effects and status of secularism, even where that system has been repressive and ineffectual. As Mardin argues " $[\mathrm{w}]$ hat we still need today is a reconstitution of the process that led to the emergence of the AKP [Justice and Development Party]"457 for which, this dissertation argues structural analyses are inadequate.

This dissertation followed a more agency-centered analysis focusing on the identities and the internal dynamics of the actors. The legacy and the impact of the Turkish Islamic movements in response to the changes and challenges typified in the Republican period led to the construction of the Turkish Islamic political identity and the change and continuity of this

\footnotetext{
${ }^{456} \operatorname{Mardin} 2006,13$.

${ }^{457}$ Mardin 2005, 146. Italics are original.
} 
identity in different periods among different groups. In this sense, based on the differences within and among different Islamic groups, this dissertation argued that, à la Wendt, ${ }^{458}$ Islam is what Muslims make of it.

As a result, I criticized the fixed definition of Islamic identity where the institutional-essentialist scholars argue that there is an essential unchanging Islam. For these scholars, Islam has frozen in time fourteen hundred years ago and cannot accommodate the environment of the modern world. For them, Islam needs and seeks power to exercise control over others, as if Muslims are always looking outward. The power-seeking radicals who often times use even democratic processes clearly represent Islam's reactionary nature. The Justice and Development Party's unique actions certainly do not fit into this picture. However, in any given religion there are different features of the religion that even the political actors can adhere to. The Hadith of Gabriel provided the type used for this study to show the plurality of the Islamic movements and in which ways they influenced the Justice and Development Party governments.

${ }^{458}$ Wendt 1992. 


\section{LIST OF REFERENCES}

Abu-Manneh, Butrus. 1982. "The Naqshbandiyya-Mujaddidiyya in the Ottoman Lands in the Early 19th Century." Die Welt des Islams, 22 (1-2):1-36.

Abu-Rabi, Ibrahim, ed. 2003. Islam at the Crossroads: On the Life and Thought of Bediüzzaman Said Nursi. Albany: SUNY Press.

Ahmad, Feroz. 1991."Politics and Islam in Modern Turkey." Middle Eastern Studies, 27 (1) 3-21.

Agai, Bekim. 2003. "The Gulen Movement's Islamic Ethic of Education." In Turkish Islam and the Secular State, edited by M. Hakan Yavuz and John L. Esposito. Syracuse: Syracuse University Press.

Ahmad, Feroz. 1993. The Making of Modern Turkey. New York: Routledge.

Ahmad, Feroz. 2005. Turkey, the Quest for Identity, Oxford: OneWorld Publications.

AK Parti. 2002. Parti Programı (Party Program). Ankara: AK Parti.

Akar, Mehmet. 2008. Seyda. Istanbul: Sahdamar Yayinlari.

Akbulut-Kuru, Zeynep and Ahmet Kuru. 2008. "Apolitical Interpretation of Islam: Said Nursi's Faith-Based Activism in Comparison with Political Islamism and Sufism" Islam and Christian-Muslim Relations 19 (1) 99-111.

Akçakoca, Amanda. 2009. " Turkish Foreign Policy - between East and West?" European Policy Centre Policy Brief. October.

Akdoğan, Yalcin. 2004. AK Parti ve Muhafazakar Demokrasi (AK Party and Conservative Democracy). Istanbul: Alfa.

Aksin, Sina. 2007. Turkey from Empire to Revolutionary Republic: The Emergence of the Turkish Nation from 1789 to Present. New York: New York University Press.

Aktay, Yasin. 2003. "Diaspora and Stability: Constitutive Elements in a Body of Knowledge." In Turkish Islam and the Secular State: The Gülen Movement, edited by M. Hakan Yavuz and John L. Esposito. Syracuse: Syracuse University Press.

Akyol, Mustafa. 2009. "What Makes Turkish Islam Unique?" In Turkey's Accession to the European Union. Athens: Springer. 
Algar, Hamid. 1999. "From Kashgar to Eyup: The Lineages and Legacy of Sheikh Abdullah Nidai." In Naqshbandis in Western and Central Asia; Change and Continuity, edited by Elisabeth Ozdalga, 1-15. Istanbul: Swedish Research Institute in Istanbul.

Algar, Hamid. 2001. "The Centennial Renewer: Bediuzzaman Said Nursi and the Tradition of Tajdid." Journal of Islamic Studies 12 (3), 291-311.

Altunisik, Meliha Benli. 2005. "The Turkish Model and Democratization in the Middle East" Arab Studies Quarterly 27 (1\&2): 45-64

Aral, Berdal. 1997. "Turkey's Insecure Identity from the Perspective of Nationalism." Mediterranean Quarterly Winter: 77-91.

Aral, Berdal. 2001. "Dispensing with Tradition? Turkish Politics and International Society during thr Ozal Decade, 1983-1993." Middle Eastern Studies 37 (1): 7288.

Aral, Berdal. 2005. "An Inquiry into the D-8 Experiment: An Incipient Model of an Islamic Common Market?" Alternatives 4 (1\&2): 89-107.

Aras, Bulent. 1998. "Turkish Islam's Liberal Face." Middle East Quarterly 5 (3): 23-31

Aras, Bulent. 2000."Turkish Foreign Policy and Jerusalem: Towards a Societal Construction of Foreign Policy." Arab Studies Quarterly 23 (4): 31-59.

Aras, Bulent and Omer Caha. 2000. "Fethullah Gulen and His Liberal "Turkish Islam" Movement." Middle East Review of International Affairs 4 (4): 30-42.

Armstrong, Karen. 2000. Islam: A Short History. Modern Library, 2000.

Atay, Rifat. 2007. "Reviving the Suffa Tradition." In Muslim World in Transition: Contributions of the Gülen Movement, edited by Ihsan Yilmaz et al. Leeds: Leeds Metropolitan University Press.

Aydin, Necati. 2005. "Virtue vs. Decadence: The Struggle of Civilizations within the Global Village." In Globalization, Ethics and Islam, edited by Ian Markham and Ibrahim Ozdemir. Aldershot: Ashgate.

Babinger, Franz. 2004. Müteferrika ve Osmanlı Matbaası (Muteferrika and the Ottoman Press), translated by Nedret Kuran Burcoglu. Istanbul: Tarih Vakfi Yurt Yayinlari.

Bacık, Gökhan. 2001. "The Limits of Alliance: The Turkish Israeli Relations Revisited." Arab Studies Quarterly 23 (3): 49-63. 
Bacık, Gökhan and Bülent Aras. 2002. "Exile: A Keyword to Understand Turkish Politics." The Muslim World 92 (3): 147-161.

Barlas, Mehmet. 2000. Turgut Özal'ın Anıları (Memoirs of Turgut Özal). Istanbul: Birey Yayinlari.

Barkan, Ömer Lütfi. 1942. "Osmanli Imparatorlugunda bir Iskan ve Kolonizasyon Metodu olarak Vakflar ve Temlikler Istila Devirlerinin Kolonizator Turk Dervisleri ve Zaviyeler." Vakıflar Dergisi II: 279-304.

Berkes, Niyazi. 1998. The Development of Secularism in Turkey. New York: Routledge.

Beyhan, Mehmet Ali. 2002. "II. Abdulhamid Doneminde Hafiyye Teskilatlari ve Jurnaller." Turkler Ansiklopedisi: 939-949.

Bilgin, Hasret Dikici. 2008. "Foreign Policy Orientation of Turkey's Pro-Islamist Parties: A Comparative Study of the AKP and Refah." Turkish Studies 9 (3): 407-421.

Bir, Çevik and Martin Sherman. 2002. "Formula for Stability: Turkey Plus Israel." Middle East Quarterly 9 (4): 23-32.

Bozdaglioglu, Yucel. 2003. Turkish Foreign Policy and Turkish Identity, a Constructivist Approach. London: Routledge.

Brodeur, Patrice C. 2005. "The Ethics of Bediuzzaman Said Nursi's Dialogue with the West in Light of his Concept of 'Europe."' In Globalization, Ethics and Islam edited by Ian Markham and Ibrahim Ozdemir. Aldershot: Ashgate.

Bruce, Steve. 2002. God is Dead: Secularization in the West. Malden: Blackwell.

Bruinessen, Martin Van. 1992. Agha, Shaikh and State. The Social and Political Structures of Kurdistan. London: Zed Books.

Bulac, Ali. 2007. Din-Kent ve Cemaat: Fethullah Gülen Ornegi (Religion-Urbanization and Community: Fethullah Gülen Case). Istanbul: Ufuk Kitap.

Bulliet, Richard W. 1994. Islam: The View from the Edge. New York; Columbia University Press.

Bulliet, Richard W. 1996. "The Individual in Islamic Society." In Religious Diversity and Human Rights, edited by Irene Bloom, J. Paul Martin and Wayne L. Proudfoot. New York: Columbia University Press. 
Buzan, Barry, Ole Waever and Jaap de Wilde. 1998. Security: A New Framework for Analysis. Boulder: Lynne Rienner Publishers.

Canan, Ibrahim. 2007. Fethullah Gülen'in Sunnet Anlayisi (The Sunnah Understanding of Fethullah Gülen). Istanbul: Ufuk Kitap.

Candar, Cengiz. 1999." Redefining Turkey's Political Center." Journal of Democracy 10 (4) $129-141$.

Celik, Omer. 2003. "'Turkey and the Fate of Political Islam" " In The United States and Turkey: Allies in Need, edited by Morton Abramowitz. New York: Century Foundation Press.

Cetinsaya, Gokhan. 1999. "Rethinking Nationalism and Islam: Some Preliminary Notes on the Roots of 'Turkish-Islamic Synthesis' in Modern Turkish Thought." Muslim World 89 (3-4): 350-376.

Chittick, William C. 1992. Faith and Practice of Islam: Three Thirteen Century Sufi Texts. Albany: State University of New York Press.

Constantinides, Stephanos. 1996. "Turkey: The Emergence of a New Foreign Policy The Neo-Ottoman Imperial Model." Journal of Political and Military Sociology 24: 323-334.

Cornell, Svante E. 1999. "Turkey: Return to Stability?" Middle Eastern Studies 35 (4): 209-234.

Davison, Andrew. 2003. "Turkey a "Secular" State? The Challenge of Description." The South Atlantic Quarterly 102 (2/3): 333-350.

Davutoğlu, Ahmet.1997. "Medeniyetlerin Ben-idraki." (Self-Concept of Civilizations) Divan, 1: 1-53.

Davutoğlu, Ahmet. 2001. Stratejik Derinlik: Turkiye'nin Uluslararasi Konumu (Strategic Depth: Turkey's International Position). Istanbul: Kure Yayinlari.

Davutoğlu, Ahmet. 2004. "Türkiye Merkez Ülke Olmalı" (Turkey Should be a Pivotal Country) Radikal. February 26.

Davutoğlu, Ahmet. 2006 [2002]. Kuresel Bunalim (Global Crisis). Istanbul: Kure.

Demir, C. Engin, A. Balci, and F. Akkok. 2000. "The Role of Turkish Schools in the Educational System and Social Transformation of Central Asian Countries: The Case Turkmenistan and Kyrgyztan." Central Asian Survey 19 (1): 141-155 
Duran, Burhanettin. 2006. "JDP and Foreign Policy as an Agent of Transformation." in The Emergence of a New Turkey: Democracy and the AK Parti, edited by Hakan Yavuz. Salt Lake City: Utah University Press.

Erbakan, Necmettin. 1971. Turkiye ve Ortak Pazar (Turkey and Common Market). Istanbul: Furkan Yayinlari.

Erdagi, Mehmet Sadik. 2007. Hatiralarin Izinde Bediuzzaman (Memories with Bediuzzaman). Ankara: Kitab-i Hayat.

Erdogan, Latif. 1995. Fethullah Gülen Hocaefendi Kucuk Dunyam (Fethullah Gülen Hocaefendi: My Small World). Istanbul: AD.

Erdogan, Mustafa. 1999. "Islam in Turkish Politics: Turkey's Quest for Democracy without Islam.' Critique: Critical Middle Eastern Studies 8 (15):24-49.

Eris, Metin 2002. "Osmanlı Devleti'nde Batılılaşma Hareketleri," (westernization Movements in the Ottoman Stte) Turkler Ansiklopedisi, 14: 593-605.

Ersöz, Ahmet. 1991. Alvarlı Efe Hazretleri (Hace Muhammed Lutfi Efendi). Izmir: Nil.

Esposito, John L., 2003. The Oxford Dictionary of Islam. Oxford: Oxford University Press.

Faroqhi, Suraiya. 1976. "The Tekke of Haci Bektas: Social Position and Economic Activities." International Journal of Middle East Studies 7 (2): 183-206.

Fethullah Gülen Web Sitesi 2008a. 1941-1959 Hayat Kronolojisi (1941-1959 Life Chronology) http://tr.fgulen.com/content/view/3502/128/. August 8, 2008

Fethullah Gülen Web Sitesi 2008b. 1960-1970 Hayat Kronolojisi (1960-1970 Life Chronology) http://tr.fgulen.com/content/view/3501/128/. August 8, 2008.

Fethullah Gülen Web Sitesi 2008c. 1971 -1979 Hayat Kronolojisi (His Life Chronology 1971-1979). http://tr.fgulen.com/content/view/3500/128/. August 11, 2008.

Friedmann, Thomas. 2007. The World is Flat: a Brief History of the Twenty-First Century. New York: Farrar, Straus and Giroux.

Friedmann, Yohanan. 2000. Shaykh Ahmad Sirhindi An Outline of His Thought and a Study of His Image in the Eyes of Posterity. Oxford: Oxford University Press.

Geertz, Clifford. 1968. Islam Observed: Religious Development in Morocco and Indonesia. Chicago: University Of Chicago Press. 
Gökalp, Ziya. 1976. Türkleşmek, İslâmlaşmak, Muasırlaşmak. Istanbul Devlet Kitapları.

Gökcek, Mustafa. 2007 "Gülen and Sufism: A Historical Perspective." In Muslim Citizens of the Globalized World: Contributions of the Gülen Movement, edited by Robert A. Haunt and Yuksel A. Aslandogan. New Jersey: The Light.

Gole, Nilufer. 1996. The Forbidden Modern. Ann Arbor: University of Michigan Press.

Gole, Nilufer. 2000. "Snapshots of Islamic Modernities," Daedalus: Journal of the American Academy of Arts and Sciences 129 (1): 91-118.

Gülen, M. Fethullah. 1977. Altın Nesil Konferansı (Golden Generation Conference). http://tr.fgulen.com/content/view/7835/85. Accessed on January 12, 2009.

Gülen, M. Fethullah. 1991. Zamanin Altin Dilimi (Golden Slice of Time). Izmir: TOV.

Gülen, M. Fethullah. 1994. Kalbin Zümrüt Tepeleri-1 (Emerald Heights of the Heart-1). Izmir: Nil.

Gülen, M. Fethullah. 1997a. Asrin Getirdigi Tereddutler 3 (Contemporary Questions - 3). Izmir: TOV

Gülen, M. Fethullah.1997b. Sonsuz Nur (The Infinite Light). Izmir: Nil.

Gülen, M. Fethullah. 1998a. Irsad Ekseni. Izmir: Zaman.

Gülen, M. Fethullah. 1998b. Ruhumuzun Heykelini Dikerken. Izmir: Nil.

Gülen, M. Fethullah. 2000. "At the Treshold of a New Millennium." The Fountain 3 (29): 7-8.

Gülen, M. Fethullah. 2000. "The Necessity of Interfaith Dialogue." The Fountain 3 (31): $7-8$.

Gülen, M. Fethullah. 2001. "A Comparative Approach to Islam and Democracy." SAIS Review 21 (2): 133-38.

Gündüz, Irfan. 1984. Gümüshanevi Ahmed Ziyauddin(KS) Hayati-Eserleri-Tarikat Anlayisi ve Halidiyye Tarikati (His Life, Works, Tariqah Understanding and Khalidyye Tariqah). Ankara: Seha.

Güngor, Erol. 1996. Islamin Bugunku Meseleleri (Contemporary Problems of Islam). Istanbul: Otuken. 
Gürdoğan, Ersin Nazif. 2008. Görünmeyen Üniversite (The Invisible University). Istanbul: Iz Yayincilik.

Haddad, Yvonne Y. and John O. Voll. 1999. The Contemporary Islamic Revival: A Critical Survey and Bibliography. New York: Greenwood Press.

Haddad, Yvonne Y. 2003. "Ghurbah as Paradigm for Muslim Life." In Islam at the Crossroad: On the Life and Thought if Bediuzzaman Said Nursi, edited by Ibrahim M. Abu-Rabi. New York: SUNY.

Hall, Martin, and Patrick Thaddeus Jackson. 2007. "Introduction: Civilizations and International Relations Theory." In Civilizational Identity: The Production and Reproduction of "Civilizations: in Internatioal Relations, edited by Martin Hall and Patrick Thaddeus Jackson. New York: Palgrave Macmillan.

Halliday, Fred. 1978. Iran: Dictatorship and Development. New York: Penguin.

Hamidullah, Muhammed. 1990. Islam Peygamberi (Prophet of Islam). Istanbul, Irfan Yayimcilik.

Hanioglu, Sukru. 2001. Preparation for a Revolution: The Young Turks 1902-1908. Oxford: Oxford University Press.

Hanioglu, Sukru. 2008. A Brief History of the Late Ottoman Empire. Princeton: Princeton University Press.

Heper, Metin. 1997. " Islam and Democracy in Turkey: Toward a Reconciliation?" Middle East Journal 51 (1): 32-45.

Heper, Metin. 2000. "The Ottoman Legacy and Turkish Politics." Journal of International Affairs 54 (1): 63-82.

Heper, Metin and Şule Toktaş. 2003. "Islam, Modernity, and Democracy in Contemporary Turkey: The Case of Recep Tayyip Erdoğan." Muslim World 93: 157-185.

Hitti, Philip Khuri. 1970. Islam, a Way of Life. University of Minnesota Press.

Hobbes, Thomas. 2005. Leviathan. Broadview Press.

Hodgson, Marshall G. S. 1974. The Venture of Islam: Conscience and History in a World Civilization. Vol. 3 The Gunpowder Empires and Modern Times. Chicago: The University of Chicago Press. 
Hopf, Ted. 2002. Social Construction of International Politics: Identities \& Foreign Policies, Moscow 1955 \& 1999. New York: Cornell University Press.

Houston, Christopher. 2004. "Islamism, Castoriadis and Autonomy." Thesis Eleven, 76: 49-69.

Huntington, Samuel P. 1996. The Clash of Civilizations and the Remaking of World Order. New York: Simon \& Schuster.

İhsan D. Dağı. 1998. Kimlik, Söylem ve Siyaset: Doğu-Batı Ayrımında Refah Partisi Geleneği (Identity, Discourse and Politics: History of Welfare Party in East-West Divide). Ankara: İmge Kitabevi.

Inalcik, Halil. 1993. The Ottoman Empre: The Classical Age 1300-1600. New York: Praeger Publishers.

Jacoby, Tim. 2004. Social Power and the Turkish State, London: Frank Cass.

Jenkins, Gareth. 2003. "Muslim Democrats in Turkey?" Survival 45(1): 45-66.

Jenkins, Gareth. 2008. Political Islam in Turkey. New York: Palgrave.

Kadri, Ali. 1994. Tarikati-i Naksibendiye Prensipleri (Principles of Naksibendi Tariqah). Istanbul: Pamuk.

Kamrava, Mehran. 1998. "Pseudo-Democratic Politics and Populist Possibilities: The Rise and Demise of Turkey's Refah Party." British Journal of Middle Eastern Studies 25 (2): 275-301.

Kandiyoti, Deniz and Ayse Saktanber. 2002. Fragments of Culture: The Everyday of Modern Turkey. New Jersey: Rutgers University Press.

Kaplan, Sam. 2002. "Din-u Devlet All over Again? The Politics of Military Secularism and Religious Militarism in Turkey." International Journal of Middle East Studies 34 (1): 113-127.

Kara, Ismail. 1999. "Ulema-siyaset ilişkilerine dair metinler - II: Ey Ulema! Bizim gibi konuş! (Documents on Ulema-Politics Relations - II: O Ulema! Talk like us!)" Divan 2: 65-134.

Kara, Ismail. 2001. Turkiye'de Islamcilik Dusuncesi: Temel Metinler. Istanbul: Gercek Hayat.

Karpat, Kemal H. 2002. Studies on Ottoman Social and Political History: Selected Articles and Essays. Leiden: Brill. 
Kısakürek, Necip Fazıl. 1996. Başbuğ Velilerden 33, Istanbul: Buyuk Dogu Yayınları.

Kısakürek, Necip Fazıl. 1984. O ve Ben. Istanbul: Buyuk Dogu Yayinlari.

Kilinc, Ramazan. 2002. "Muhafazakarlik: II. Abdulhamid Donemini Anlamada Bir Anahtar." (Conservatism: A Key to Understand the Abdulhamid II Era) Turkler Ansiklopedisi, 12: 931-938.

Koprulu, Mehmet Fuat. 1992. The Origins of the Ottoman Empire, translated by Gary Leiser. Albany: State University of New York Press.

Kosoglu, Nevzat. 2004. Bediuzzaman Said Nursi: Hayati- Yolu-Eseri (His Life, Way and Work). Istanbul: Otuken.

Kotku, Mehmed Zahid. 1984. Nefsin Terbiyesi. Ankara: Seha Nesriyat.

Kubálková, Vendulka. 2003."Toward an International Political Theology." In Religion and International Relations. The Return from Exile, edited by Fabio Petito and Pavlos Hatzopoulos, New York: Palgrave.

Kuru, Ahmet T. 2003. "Fethullah Gülen's Search for a Middle Way Between Modernity and Muslim Tradition." In M. Hakan Yavuz and John L. Esposito, eds.Turkish Islam and the Secular State: The Gülen Movement. Syracuse: Syracuse University Press.

Kuru, Ahmet T. 2009. Secularism and State Policies Toward Religion: The United States, France and Turkey. New York: Cambridge University Press.

Kurucan, Ahmet. 1997. "Takdim" in Fasildan Fasila 1 by Fethullah Gülen. Izmir: Nil.

Lapidus, Ira. M. 1994. A History of Islamic Societies. New York: Cambridge University Press.

Le Gall, Dina. 2003. "Forgotten Naqshbandis and the Culture of Pre-Modern Sufi Brotherhoods." Studica Islamica 97: 87-119.

Lewis, Bernard. 1990. "The Roots of Muslim Rage: Why So Many Muslims Deeply Resent the West, and Why Their Bitterness Will Not Easily Be Mollified." The Atlantic Monthly (266): 47-60.

Lewis, Bernard. 1997. "The West and the Middle East." Foreign Affairs 76 (1):114-130

Lewis, Bernard. 2002[1961]. The Emergence of Modern Turkey. London: Oxford University Press. 
Lewis, Bernard. 2003. What Went Wrong? The Clash between Islam and Modernity in the Middle East. New York: Perennial.

Lings, Martin. 1971 [1961]. A Sufi Saint of the Twentieth Century Shaikh Ahmad alAlawi His Spiritual Heritage and Legacy. London: George Allen \& Unwin Ltd.

Madelung, Wilferd. 1997. The Succession to Muhammad. Cambridge: Cambridge University Press

Mahfuz, Naguib. 1996. Children of the Alley. New York: Doubleday.

Mandaville, Peter. 2001. Transnational Muslim Politics: Reimagining the Umma. London: Routledge.

Mango, Andrew. 1993. "The Turkish Model" Middle Eastern Studies 29 (4)" 726-757.

Mardin, Şerif. 1956. "Din Iptidailigi." Forum 4 (44): 10-11.

Mardin, Şerif. 1962. The Genesis of Young Ottoman Thought. Princeton: Princeton Universoty Press.

Mardin, Şerif. 1982. "Bediuzzaman Said Nursi (1873-1960): The Shaping of a Vocation." In Religious Organization and Religious Experience, edited by J. Davis, 65-79. London: Academic Press.

Mardin, Şerif. 1983. "Religion and Politics in Modern Turkey." In Islam in the Political Process, edited by James Piscatori. Cambridge: Press Syndicate of the University of Cambridge.

Mardin, Şerif. 1989. Religion and Social Change in Modern Turkey: The Case of Bediüzzaman Said Nursi. New York: State University of New York Press.

Mardin, Şerif. 1991."The Naksibendi Order of Turkey." In Fundamentalisms and the State, edited by Martin E. Marty. Chicago: The University of Chicago Press.

Mardin, Şerif. 2005 [1991]. Turkiye'de Din ve Siyaset. Istanbul: Iletisim.

Mardin, Serif. 2005. "Turkish Islamic Exceptionalism Yesterday and Today: Continuity, Rupture and Reconstruction in Operational Codes." Turkish Studies 6 (2): 145165.

Mardin, Şerif. 2006. "Turkish Islamic Exeptionalism Yesterday and Today: Continuity, Rupture and Reconstruction in Operational Codes." In Religion and Politics in Turkey, edited by Ali Carkoglu and Barry Rubin. New York: Routledge. 
Markham, Ian and Ibrahim Ozdemir. 2005. Globalization, Ethics and Islam. Aldershot: Ashgate.

Mecham, R. Quinn. 2004. "From the Ashes of Virtues, a Promise of Light: The Transformation of Political Islam in Turkey." Third World Quarterly 25 (2): 339358.

Memis, Abdurrahman. 2000. Halidi Bagdadi ve Anadoluda Halidilik (Khalid-i Baghdadi and Khalidiyye in Anatolia). Istanbul: Kitabevi.

Mesbahi, Mohiaddin. 1994. "Regional and Global Powers and the International Relations of Central Asia." In The Making of Foreign Policy in Russia and the New States of Eurasia, edited by Adeed Dawisha and Karen Dawisha, 215-245. Armonk: M.E. Sharpe.

Mesbahi, Mohiaddin. 2010. "Eurasia between Russia, Turkey and Iran." In Russia in Eurasia: External Players and Dynamics, edited by Roger Kanet and Maria Raquel Freire. New York: Palgrave.

Metiner, Mehmet. 2008. Yemyesil Seriat Bembeyaz Demokrasi (Green Sharia White Democracy). Istanbul: Dogan Kitapcilik.

Murata, Sachiko and William C. Chittick. 2006 [1994]. The Vision of Islam. London and New York: I.B. Tauris.

Murinson, Alexander. 2006. "The Strategic Depth Doctrine of Turkish Foreign Policy." Middle Eastern Studies 42 (6): 945 - 964.

Naiupul, V. S. 1991. "Our Universal Civilization." The New York Review of Books 38 (3).

Nawawi, Imam. 1996. Forty Hadith. Kuala Lumpur: Islamic Book Trust.

Nizami, K. A. 1991. "The Naqshbandiyyah Order." In Islamic Spirituality: Manifestations, edited by Seyyed Hossein Nasr, 162-193. New York: Crossroad Pulishing Company.

Nursi, Bediüzzaman Said. 1996. Risale-i Nur Külliyatı. Vol. 1-2. Istanbul: Yeni Asya Yayinlari.

Önis, Ziya. 1997. "The Political Economy of Islamic Resurgence in Turkey, the Rise of the Welfare Party in Perspective," Third World Quarterly 18 (4) 743-766. 
Önis, Ziya. 2004. "Turgut Ozal and his Economic Legacy: Turkish Neo-Liberalism in Critical Perspective" Middle Eastern Studies 40 (4): 113-134.

Onuf, Nicholas. 1991. "Sovereignty: Outline of a Conceptual History." Alternatives 16: 447-477.

Ortayli, İlber. 2006. Son Imparatorluk Osmanli. Istanbul: Timas.

Özal, Korkut. 1994. Gercek Tanik Korkut Özal Anlatiyor. Istanbul: Milliyet Yayinlari.

Özal, Korkut. 1999."Twenty Years with Mehmed Zahid Kotku." In Naqshbandis in Western and Central Asia, edited by Elisabeth Özdalga, 159-176. Istanbul: Sweedish Research Institute in Istanbul.

Özbudun, Ergun. 1996. "The Continuing Ottoman Legacyand the State tradition in The Middle East." In Imperial Legacy: The Ottoman Imprint on the Balkans and the Middle East, edited by Carl Brown. New York: Princeton University Press.

Özdalga, Elisabeth, ed. 1999. Naqshbandis in Western and Central Asia. Istanbul: Swedish Research Institute in Istanbul.

Öztürk, Asiye. 2009. "The Domestic Context of Turkey's Changing Foreign Policy towards the Middle East and the Caspian Region." Bonn: Deutsches Institut für Entwicklungspolitik.

Parslow, Joakim. 2007 " Turkish Political Parties and the European Union: How Turkish MPs Frame the Issue of Adapting to EU Conditionality." Arena Report. Oslo: Center for European Studies.

Pashayan, Araxs. 2007. "Integration of Muslims in Europe and Gulen Movement." in Peaceful Coexistence Fethullah Gülen's Initiatives in the Contemporary World, edited by Ihsan Yilmaz. London: Leeds Metropolitan University Press.

Petito , Fabio and Pavlos Hatzopoulo, eds 2003. Religion in International Relations: The Return From Exile, New York: Palgrave-Macmillan.

Pipes, Daniel. 2003. In the Path of God: Islam and Political Power. New Jersey: Transaction Publishers.

Pippin, Robert B. 1997. Idealism as Modernism: Hegelian Variations. Cambridge: Cambridge University Press.

Piscatori, James P. 1988. Islam in a World of Nation-States. New York: Cambridge University Press. 
Rashwan, Diaa, ed. 2007. The Spectrum of Islamist Movements. Berlin: Schiler.

Risale-i Nur Enstitusu. 2000. " Bediüzzaman Hangi Tarihte Doğdu? (When was Bediuzzaman Born?)", Kopru 70

Robins, Phillip. 1997. "Turkish Foreign Policy under Erbakan." Survival: Global Politics and Strategy. 39 (2): 82-100.

Robins, Philip. 2003a." Confusion at Home, Confusion Abroad: Turkey between Copenhagen and Iraq." International Affairs (Royal Institute of International Affairs) 79 (3): 547-566.

Robins, Phillip. 2003b. Suits and Uniforms: Turkish Foreign Policy since the Cold War. London: Hurst \& Company.

Robins, Philip. 2007a. "Turkish Foreign Policy since 2002: Between a 'post-Islamist' Government and a Kemalist State" International Affairs 83 (2): 289-304.

Robins, Philip. 2007b. "Between the EU and the Middle East: Turkish Foreign Policy under the AKP Government, 2002-2007." Milano: ISPI Working Papers.

Rouleau, Eric. 1996. "Turkey: Beyond Ataturk." Foreign Policy 103: 70-87.

Rubin, Michael. 2004. "Shifting Sides? The Problems of Neo-Ottomanism." National Review Online August 10.

Safa, Peyami. 1995. Fatih-Harbiye. Istanbul: Otuken Nesriyat.

Said, Edward W. 1979. Orientalism. New York: Vintage Books.

Saktanber, Ayse. 2002. Living Islam: Women,Religion and the Politicization of Culture in Turkey. London: I.B. Tauris.

Savvides, Philippos K. 2000. "Legitimation Crisis and Securitization in Modern Turkey." Critique 16: 55-73.

Sayyid, S. 2003. A Fundamental Fear: Eurocentrism and the Emergence of Islamism. London: Zed Books.

Schimmel, Annemarie. 1973. "The Sufi Ideas of Shaykh Ahmad Sirhindi." Die Welt des Islams 14 (1): 199-203.

Selim, Yavuz. 2002. Gül'ün Adl. Ankara: Kim Yayınları. 
Sencer, Muammer and Mehmet Ali Yalcin, eds. 2006. Hitler'in Türk Dostlari. Istanbul: Dus Yayinlari

Sevilgen, M. Gündüz. 1979. MSP'de Dört Yll (1973-1977). Ankara: Istiklal Matbaasi.

Sevindi, Nevval, ed. 2008. Contemporary Islamic Conversations: M. Fethullah Gülen on Turkey, Islam, and the West, translated by Abdullah T. Antepli. Albany, NY: SUNY Press.

Shah-Kazemi, Reza. 2006. The Other in the Light of the One: The Universaity of the Qur'an and Interfaith Dialogue.Cambridge: Islamic Texts Society.

Shaw, Stanford J. and Ezel Kural Shaw. 1977. History of the Ottoman Empire and Modern Turkey Volume II: Reform, Revolution, and Republic: The Rise of Modern Turkey, 1808-1975. London: Cambridge University Press.

Smith, Wilfred Cantwell. 1978. The Meaning and End of Religion. San Francisco: Harper \& Row.

Smith, Thomas W. 2005a. "Between Allah and Atatürk: Liberal Islam in Turkey." International Journal of Human Rights 9 (3): 307-325.

Smith, Thomas W. 2005b."Civic Nationalism and Ethnocultural Justice in Turkey." Human Rights Quarterly 27 (2): 436-470.

Şahiner, Necmeddin. 2006. Bilinmeyen Taraflariyla Bediuzzaman Said Nursi.Istanbul: Nesil.

Şener, Abdulkadir. n.d. "İslam'da Mezhebler ve Hukuk Ekolleri." (Madhabs and Legal Schools in Islam) Ankara Üniversitesi Illahiyat Fakültesi Dergisi 26: 371-406.

Tanıyıc1, Saban. 2003. 'Transformation of Political Islam in Turkey: Islamist Welfare Party's Pro-EU Turn,' Party Politics 9: 463-483.

Tarrow, Sidney. 1994. Power in Movement: Social Movements, Collective Action and Politics. New York: Cambridge University Press.

Taspinar, Ömer. 2008. "Turkey’s Middle East Policies Between Neo-Ottomanism and Kemalism." Carnegie Papers 10: 1-29.

Tepe, Sultan. 2005. "Turkey's AKP: A Model 'Muslim-Democratic' Party?" Journal of Democracy 16 (1): 69-82. 
Tezcur, Murat. 2005. How Do Political Religious Movements Develop Sustainable Democratic Commitments: The Cases of Iran and Turkey. Unpublished Dissertation. The University of Michigan.

Tibi, Bassam. 2002. Islam Between Culture and Politics. New York: Palgrave.

Toynbee, Arnold. 1965. A Study of the History. Vol. 1. New York: Oxford University Press.

Tunander, Ola. 1995. "A New Ottoman Empire? The Choices for Turkey: Euro-Asian Centre vs National Fortress." Security Dialogue 26 (4): 413-426.

Tunaya, Tarik Zafer. 2003. Islamcilik Akimi. Istanbul: Istanbul Bilgi Universitesi Yayinlari.

Tunaya, Tarik Zafer. 2004. Turkiye'nin Siyasi Hayatinda Batililasma Hareketleri. Istanbul: Istanbul Bilgi Universitesi Yayinlari.

Vahide, Sukran. 2005a. "Bediuzzaman Said Nursi and the Risale-i Nur." In Globalization, Ethics and Islam, edited by Ian Markham and Ibrahim Ozdemir. Aldershot: Ashgate.

Vahide, Sukran. 2005b. Islam in Modern Turkey: An Intellectual Biography of Bediuzzaman Said Nursi. New York: State University of New York Press.

Veinstein, Gilles. 2004. "Önsoz (Introduction)." In Islam Dunyasinda Tarikatlar (Tariqahs in the Islamic World), edited by Alexandr Popovic and Gilles Veinstein, translated by Osman Turer. Istanbul: Suf Yayinlari.

Wendt, Alexander. 1992. "Anarchy is What States Make of it: The Social Construction of Power Politics." International Organization 46 (2): 391-425.

Wing, Marlene. 1997. "Nicholas G. Onuf." In The Future of International Relations, edited by Iver B. Neumann and Ole Wæver. New York: Routledge.

Yasar, M. Emin. 2004. "Dergah'tan Partiye, Vakiftan Sirkete Bir Kimligin Olusumu ve Donusumu: Iskenderpasa Cemaati." In Islamcilik, edited by Yasin Aktay, 323340. Istanbul: Iletisim.

Yavuz, M. Hakan. 1997a. "Political Islam and the Welfare (Refah) Party in Turkey." Comparative Politics 30 (1): 63-82.

Yavuz, M. Hakan. 1997b. "Turkish-Israeli Relations through the Lens of the Turkish Identity Debate," Journal of Palestine Studies 27 (1) 22-37. 
Yavuz, M. Hakan. 1999. "Towards an Islamic Liberalism?: The Nurcu Movement and Fethullah Gülen," The Middle East Journal 53 (4): 584-605.

Yavuz, M. Hakan. 2000. "Cleansing Islam from the Public Sphere." Journal of International Affairs 54 (1): 21-42.

Yavuz, M. Hakan. 2003. Islamic Political Identity in Turkey. Oxford: Oxford University Press.

Yavuz, M. Hakan and John L. Esposito, eds. 2003a. Turkish Islam and the Secular State: The Gülen Movement. Syracuse: Syracuse University Press.

Yavuz, M. Hakan. 2006. The Emergence of a New Turkey: Democracy and the AK Parti. Salt Lake City: University of Utah Press.

Zubaida, Sami. 2005. Law and Power in the Islamic World. New York: I.B. Taurus.

Zürcher, Erik J. 2003. Turkey: A Modern History. New York: I.B. Tauris. 
VITA

\section{MUSTAFA GOKHAN SAHIN}

\section{EDUCATION}

Doctoral Candidate, International Relations, Florida International University, Miami, Florida. Major: Theories of International Relations, Foreign Policy and Security Studies, Minor: Islam and the Middle East

Dissertation: "Turkey and Neo-Ottomanism: Domestic Sources, Dynamics and Foreign Policy"

M.A., International Relations, Fatih University, Istanbul, August 2001

Master Thesis: "Change and Continuity in Turkish Foreign Policy with Respect to Arab-Israeli Conflict”

B.A., International Relations, Bilkent University, Ankara, January 1999

\section{PROFESSIONAL EXPERIENCE}

2006 - Adjunct Lecturer, Department of International Relations, Florida International University, Miami, Florida.

2005-2006 Regional Reports Author, Applied Research Center, Florida International University, Miami, Florida.

2004-2005 Content Editor, Hemispheric Center for Environmental Technology, Florida International University, Miami, Florida.

2003-2004 Adjunct Lecturer, Department of International Relations, Florida International University, Miami, Florida.

2001- 2003 Teaching Assistant, Department of International Relations, Florida International University, Miami, Florida.

1999-2001 Research Assistant, Department of International Relations, Fatih University, Istanbul.

\section{PUBLICATIONS: BOOK REVIEWS}

Kimlik, Soylem ve Siyaset: Dogu Bati Ayriminda Refah Partisi Gelenegi (Identity, Discourse and Politics: History of Islamist Welfare Party and the East-West Divide) by Ihsan D. Dagi, in Journal of Muslim Minority Affairs, Vol. 21, No: 2, 2001.

Palestinian-Israeli Peace Process and Turkey, by Bulent Aras; in Turkish Studies (London) Vol.1, No: 2, 2000 
Turkey's New Geopolitics from Balkans to Western China, by Graham Fuller, Ian O. Lesser, et al, in Diyalog Avrasya (Eurasia Dialogue), Summer 2000 (in Turkish and Russian)

Central Asia: Conflict, Resolution, and Change, by Roald Z. Sagdeev and Susan Eisenhower (eds.); in Diyalog Avrasya (Eurasia Dialogue), Summer 2000 (in Turkish and Russian)

\section{CONFERENCE PAPERS}

2009. "Dynamics of Islamic Political Identity in Turkey: Three Muslim Cases," Conference entitled "Fourteen Centuries of Islam's Encounter with the West," $26^{\text {th }}$ Annual American Council for the Study of Islamic Societies, University of Miami, Coral Gables, Florida. April 24-25.

2002. "Palestinian Question and Turkish Foreign Policy in the Light of Turkish Identity Debate," Conference entitled " $17^{\text {th }}$ Middle East History and Theory Conference," Center for Middle Eastern Studies, University of Chicago, Chicago, Illinois. May 10-12, 2002.

2001. "Change and Continuity vis a vis Turkish Foreign policy towards Central Asia in the post-Cold War Era" Conference entitled "The Geopolitical and Economic Transitions in Eurasia Conference," Fatih University, Istanbul May 10-12.

\section{INVITED PUBLIC LECTURES}

2008. "Judaism \& Islam - A Dialogue" Congregation B'nai Israel, Boca Raton, Florida, May 8.

2006. "The Role of Religion in Turkish Foreign Policy during the Islamist Justice and Development Party Era," Politics Platform of Turkish Students Association at Florida International University, Miami, Florida, September 3.

2005. "Islam and International Relations," Dr. Irv Berger Lecture Series, Classic Residence by Hyatt Aventura, Florida, April 11.

2003. "An Introduction to Islam," Jewish Community Center, Miami Gardens, Florida, October 24. 